\title{
YARA MALKI
}

\section{REFLEXÕES SOBRE OS TESTES}

\author{
PSI COLÓGI COS A PARTIR DA
}

\section{TEORI A CRÍ TI CA DA SOCI EDADE}

Dissertação apresentada ao Instituto de Psicologia da Universidade de São Paulo como parte dos requisitos para obtenção do grau de Mestre em Psicologia.

Área de Concentração: Psicologia Escolar.

Orientador: Prof. Dr. José Leon Crochik. 
Universidade de São Paulo

Instituto de Psicologia

\section{REFLEXÕES SOBRE OS TESTES \\ PSI COLÓGI COS A PARTIR DA TEORIA \\ CRÍ TI CA DA SOCI EDADE}

YARA MALKI

\section{BANCA EXAMI NADORA}

Prof. Dr. Odair Sass

Profa. Dra. Leny Sato

Prof. Dr. José Leon Crochik

Dissertação defendida e aprovada em ___ / __- / 2000. 
À você, Fábio.

Aos filhos que virão. 


\section{AGRADECIMENTOS}

Fábio Carvalho Pessôa - meu marido, meu amigo... Pelo carinho, apoio, compreensão, paciência e tudo o mais que só o amor torna possível.

Hikmat e Liuba Malki - meus pais, em especial minha mãe pelo incentivo constante ao estudo - embora quando ocorriam grandes ausências por causa da dissertação, lá vinha ela com “chega de estudar!"...

Francisca V. Vergueiro - minha analista, que acompanha e partilha meu caminho desde a graduação, em seus altos e baixos, idas e vindas...

Francisco Valença - por tantas coisas, mas sobretudo, pelo exemplo de amor pelo que faz e crença na vida.

Débora Bianco - de várias formas, sua influência está colocada neste trabalho.

Lígia Ferreira Galvão - sobretudo, pelo impulso inicial.

Leon Crochik - meu orientador, em especial pelo auxílio na difícil tarefa de (tentar) manter a dialética no pensamento.

Mạ da Conceição Coropos Uvaldo - pelo apoio e pela oportunidade de ter as idéias desse trabalho apresentadas para estudantes do curso de orientação profissional do Sedes Sapientae e da USP. 
Fabiano Fonseca - pela força na USP e pelas oportunidades acadêmicas na São Judas.

Leny Sato e Odair Sass - que contribuíram valiosamente na banca de qualificação. Ao prof. Odair agradeço ainda a indicação e o empréstimo do livro de Lawler (1981).

Iray C. Boccatto Alves - pelos textos indicados e emprestados, bem como pelas informações fornecidas sobre a área.

Márcia Menin - pela revisão do português, sem a qual o acabamento desse trabalho estaria bem bagunçado...

Pessoal da Biblioteca do IPUSP - sempre gentis e solícitos.

Pessoal da Sessão de Pós-Graduação do IPUSP - pela colaboração. 
“Todo progresso da civilização tem renovado, ao mesmo tempo, a dominação e a perspectiva de seu abrandamento."

Horkheimer e Adorno, Dialética do Esclarecimento. 


\section{SUMÁRIO}

RESUMO

$x$

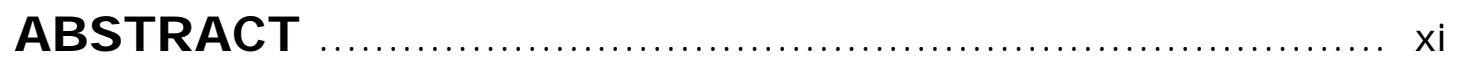

\section{1 - TÉCNICA E RAZÃo}

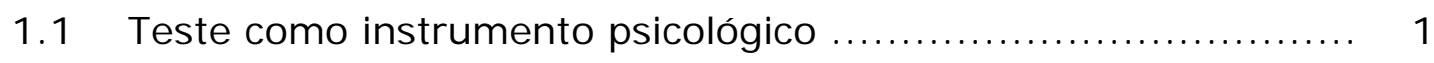

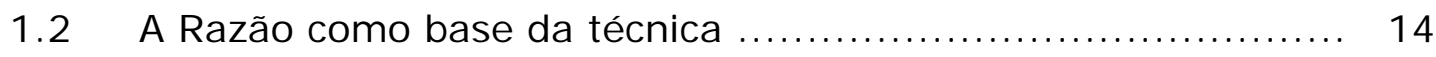

1.3 Ideologia e "monadologismo" na Teoria Crítica .................... 33

\section{2 - HISTÓRI A E CARACTERÍ STI CAS DOS TESTES PSI COLÓGI COS}

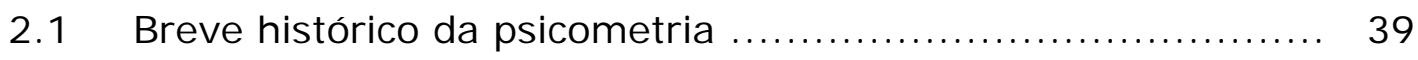

2.1.1 A psicologia da dimensão físico-natural ........................ 47

2.1.2 O emprego de testes na escola .............................. 52

2.1.3 A expansão dos testes no Brasil, no imbricamento da psicologia

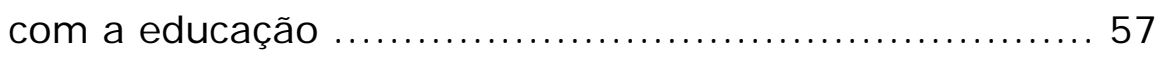

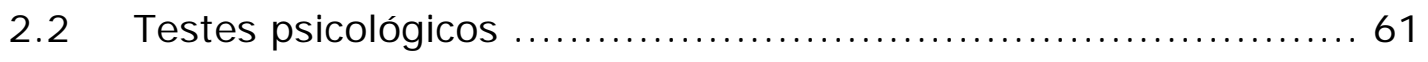


2.2.1 Características do teste: padronização, normas, precisão e validade 61

2.2.2 Classificação dos instrumentos psicológicos de medida .......... 74

2.2.3 O tríplice objetivo: precisão, rapidez e economia ................. 79

2.2.4 A avaliação por testes da clientela escolar no Brasil ............. 80

2.2.4.1 O WISC, emblema da situação nacional ......................... 83

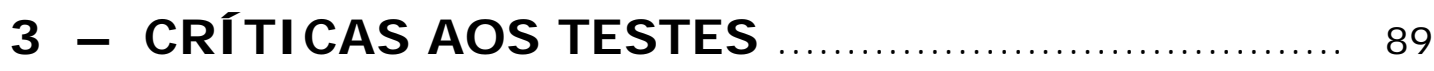

3.1 Discussões sobre a inteligência no passado: uma ilustração ..... 90

3.2 O argumento do Q.I., a nova "cara" do racismo americano ...... 92

3.3 A psicometria na justificação do fracasso escolar ................ 105

\section{4 - ATUALI ZAÇÃO DO DEBATE ........................ 112}

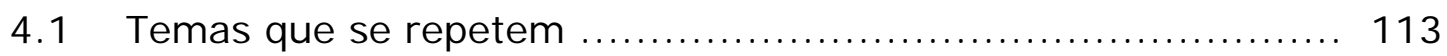

4.1.1 O que se repete no campo de uso de testes .................. 115

4.1.2 O que se repete na crítica aos testes ........................... 125

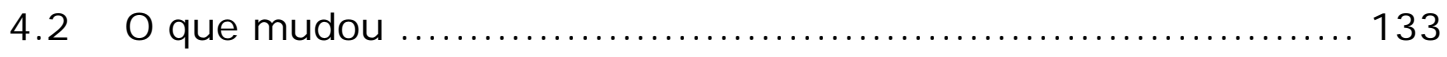

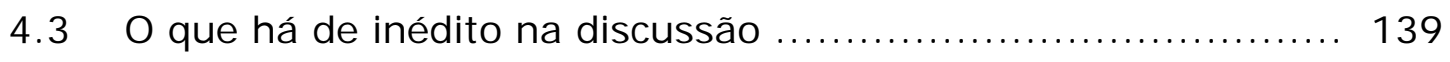




\section{5 - PARÊnteses para Repensar OS Testes}

PSI COLÓGI COS: DI ÁLOGOS COM A TEORIA

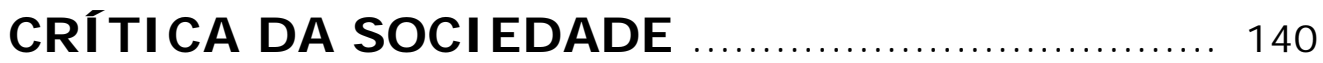

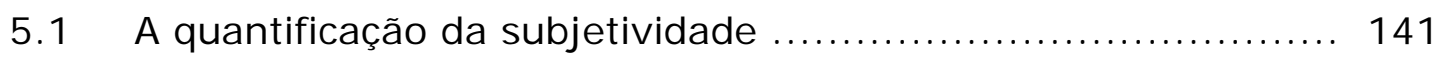

5.2 A objetividade do teste e a relação sujeito-objeto ............... 157

6 - CONSI DERAÇÕES FI NAIS ...................................... 164

REFERÊNCI AS BI BLI OGRÁFI CAS ........................... 180 


\section{RESUMO}

MALKI, Yara. Reflexões sobre os testes psicológicos a partir da Teoria Crítica da Sociedade. São Paulo, 2000, 190p. Dissertação (Mestrado). Instituto de Psicologia, Universidade de São Paulo.

Este trabalho examina os testes psicológicos, especialmente em sua relação com a educação, à luz da Teoria Crítica da Sociedade, tanto a partir de seus conceitos internos como das condições sociais e históricas que possibilitaram sua criação. Duas análises são fundamentais, ambas baseadas em Horkheimer e Adorno: primeiro, a da contradição histórica do movimento da razão ocidental, examinada a partir da Dialética do Esclarecimento; segundo, do emprego de métodos estatísticos e tipológicos em pesquisas nas ciências humanas. Como resultado da reflexão, concluiu-se que o conflito entre métodos quantitativos e qualitativos na psicologia mostra-se falso, pois servem para fins diferentes. A "naturalização", a tipologização e a indiferenciação do homem no mundo moderno não devem ser atribuídas aos testes psicológicos. Estes carregam em si a contradição do esclarecimento, de servir à humanidade e ao mesmo tempo à sua barbarização. Apresentamse nesta dissertação, ainda, alguns autores críticos aos testes e, como ilustração, uma pesquisa bibliográfica sobre os testes em dois periódicos brasileiros educacionais e dois psicológicos. Verificou-se que os testes são empregados e criticados predominantemente aderidos a seus aspectos regressivos, sem que se pudesse pensar sua transcendência, apesar das mudanças observadas na psicometria atual. 


\section{ABSTRACT}

MALKI, Yara. Reflections about psychological tests from the Critical Theory of Society. São Paulo, 2000, 190p. Master Thesis. Instituto de Psicologia, Universidade de São Paulo.

This work examines psychological tests, especially in their relation with education, from the Critical Theory of Society standpoint, considering their internal concepts as well as historic conditions that allowed their creation. Two analysis are fundamentals, both based on Horkheimer and Adorno: first, the historical contradictions of the western ratio movement, examined from the Dialectic of the Enlightenment; second, the employment of statistical and typological methods on research. As a result, it was concluded that the conflict between quantitative and qualitative methods is shown equivocated since they serve different purposes. Man's “naturalization”, typologization and indiferenciation in the modern world cannot be attributed to psychological tests. These ones carry within themselves the contradiction of the enlightenment, of serving the humanity and at the same time its barbarization. It is still presented in this thesis some critical authors to the tests, and as illustration, a bibliographic research about tests obtained from two educational Brazilian journals and two psychological ones. It was verified that tests are employed and criticized mainly linked to their regressive aspects without possibilities of thinking their transcendence, despite changes observed in present psychometry. 
Ficha Catalográfica preparada pelo Serviço de Biblioteca e Documentação do I nstituto de Psicologia da USP

Malki, Y.

Reflexões sobre os testes psicológicos a partir da teoria crítica da sociedade / Yara Malki. - São Paulo, s.n., 2000. - ???p.

Dissertação (mestrado) - Instituto de Psicologia da Universidade de São Paulo. Departamento de Psicologia da Aprendizagem, do Desenvolvimento e da Personalidade.

Orientador: José Leon Crochik

1. Testes psicológicos 2. Teoria crítica 3. Psicologia escolar 4. Adorno, Theodor Wiesengrund, 1903-1969 5. Fracasso escolar 6. Escolas 7. Horkheimer, Max, 1895-1973 I. Título. 


\section{APRESENTAÇÃo}

Através desses quatro anos de pesquisa sobre testes psicológicos, pude domar meu preconceito contra os métodos quantitativos em psicologia.

Nesse caminho, tive uma ajuda valiosa: a do meu orientador, Leon, que pôde, como poucos, me auxiliar a construir esse sofrido caminho no pensamento dialético através de Horkheimer, Adorno, Marcuse, Marx...

Hoje, além disso, fortalece em mim duas antigas certezas: a de que é sine qua non conhecer aquilo o qual se fará objeto de crítica e a outra, que aprendi de Horkheimer e Adorno, de que o pensamento deva ser duro para consigo próprio para destruir os mitos.

Observar o que no pensamento há de contraditório não significa conciliar opostos. Longe disso ser essa a intenção deste trabalho; os opostos já estão conciliados demais... 


\section{1 \\ TÉCNICA E RAZÃO}

\section{1 - Teste como instrumento psicológico}

O teste psicológico apresenta as decorrências que a técnica, de modo geral, tem no mundo contemporâneo dentro de uma sociedade capitalista. Diante disso, faz-se necessário entender que papéis uma técnica científica vem cumprir, dentro e fora da esfera da produção, num mundo em que a ciência foi incorporada ao capital e é força do aparato produtivo.

Embora os testes psicológicos não constituam um maquinário, estritamente falando, aproximam-se dele quanto ao fato de serem um instrumento tecnológico. Ainda que superficialmente 0 teste psicológico, como qualquer produto técnico, possa parecer uma ferramenta neutra de trabalho, mais aprofundadamente observa-se o quanto seu uso e existência mostram sobre a vida em sociedade, o projeto de homem e a relação deste com a natureza. A transformação 
da natureza implica a transformação do homem, e as transformações que o homem opera, como menciona Marcuse (1967), "partem de um conjunto social e reingressam nele." (p.150).

Para Marx (1975a),

\begin{abstract}
“a tecnologia revela o modo de proceder do homem para com a natureza, o processo imediato de produção de sua vida e assim elucida as condições de sua vida social e as concepções mentais que dela decorrem." (p.425).
\end{abstract}

Desse modo, justifica-se a necessidade de se voltar para a esfera da produção, fonte original dos recursos tecnológicos na sociedade capitalista, ao se analisar o teste psicológico como instrumento técnico.

O objetivo do emprego da maquinaria é a racionalização do trabalho, incrementando a produção com o mínimo de gasto. A intenção que a cerca, numa sociedade capitalista, segundo Marx (1975a), não deixa dúvidas: “a maquinaria é meio de produzir mais-valia." (p.424). O advento da indústria moderna inaugurou uma nova forma de o trabalhador se relacionar com o produto de seu trabalho, não apenas na segmentação da produção, da qual falaremos adiante, mas no fato de o trabalho passar a “operar em grande escala, gratuitamente, como se fosse uma força natural" (p.442), gerando mais-valia.

A maquinaria, segundo Crochik (1990), representa o capitalista no mundo da produção, reapresentando a dominação deste sobre o 
trabalhador. Não é neutra, embora vinda de um saber empírico que se sustenta na lógica formal, tida como neutra por não se referir ao social. A técnica é fundada não apenas visando à produção, como também na própria dominação que o lucro implica.

Marx (1975a) analisou a introdução da maquinaria moderna nas indústrias inglesas de meados do século XIX. Nessa época, a produção havia começado a entrar num ritmo frenético com a máquina a vapor, poderosa força motriz que havia livrado grande parte da produção das limitações da força humana. Novas máquinas, mais potentes e melhoradas, passaram a ser inventadas a partir das antigas, gerando um ciclo ininterrupto de aperfeiçoamento da estrutura da produção, com máquinas gerando máquinas. A invenção da máquina a vapor anunciou o fim da estabilidade produtiva que os sistemas tradicionais mantinham, iniciando a Revolução Industrial.

Com a Revolução, teve início também uma nova era nas relações de trabalho e nas formas de produção. O lucro, grande alvo a ser perseguido, começou a ser gerado em uma escala sem precedentes. Assim, aumentou a exploração sobre a força de trabalho, que passou a ser vendida como mercadoria também numa escala maior, sendo o trabalhador cada vez mais exigido. Por trás de seu novo status de "trabalhador livre", ele estava progressivamente mais preso ao ritmo da máquina e à necessidade de produção cada vez maior e mais intensa (Marx, 1975a).

Para Marx (1975a), a maquinaria impõe uma contradição, que é submeter os trabalhadores à "escravização", promovendo sua desumanização, ao mesmo tempo em que não deixa de ser 
um triunfo do homem sobre a natureza, que poderia ter como resultado uma melhoria em sua vida em vários aspectos. No seio desta contradição, no entanto, é que está, para Marx (1975a), a possibilidade de se transcender a crítica aos meios de produção e problematizar sua "forma social" (p.491) de exploração, o que leva ao questionamento do uso capitalista da maquinaria. A crítica não deve se dirigir ao maquinário como se ele existisse à revelia de suas relações sociais:

\footnotetext{
“A maquinaria, como instrumental que é, encurta o tempo de trabalho, facilita o trabalho, é uma vitória do homem sobre as forças naturais, aumenta a riqueza dos que realmente produzem, mas, com sua aplicação capitalista, gera resultados opostos: prolonga o tempo de trabalho, aumenta sua intensidade, escraviza o homem por meio das forças naturais, pauperiza os verdadeiros produtores." (p.506)
}

Uma característica fundamental que concerne à aplicação capitalista do instrumento é que o processo produtivo se inverte, ocorrendo de o "instrumental de trabalho empregar o trabalhador e não o trabalhador empregar o instrumental." (Marx, 1975a, p.484). Essa inversão refere-se ao fato de o instrumento passar a ser a base da produção, sendo o homem um figurante que ampara a máquina, a tal ponto que foi denominado por Marx (1975a) de "autômato vivo." (p. 484).

$\mathrm{Na}$ indústria moderna, o trabalho foi perdendo, a passos largos, sua dimensão qualitativa. No regime tradicional de produção, um sapateiro, por exemplo, encontraria muita dificuldade se tivesse de 
substituir repentinamente um tecelão e vice-versa, dada a especificidade do trabalho de cada qual. Com a indústria moderna, eles efetivamente deixam de ser "sapateiro" e "tecelão" e viram trabalhadores da indústria de tecelagem e de sapataria. Pouco necessitam de sua anterior qualificação, uma vez que a máquina comanda a produção e eles são coadjuvantes. Sobrou aos trabalhadores apenas o papel de peça a mais na linha de produção, que ficou praticamente independente de participação humana qualitativa, coisificando-os. Marx (1975a) observa na indústria que pessoas com qualquer qualificação profissional ou mesmo nenhuma podiam se adaptar aos novos postos de trabalho por ela criados, o que acabou facilitando a reposição dos trabalhadores.

A introdução de máquinas na produção também traz a ciência para dentro da fábrica, decompondo a produção e aprofundando a divisão entre trabalho intelectual e manual. A produção por meio do sistema mecanizado não consegue mais se sustentar pela "rotina empírica" (Marx, 1975a, p.439) e intuitiva da manufatura. Esta precisa ser substituída pela organização objetiva e "aplicação consciente da ciência." (p.439). A ciência, que já havia se integrado às forças produtivas ao criar e aperfeiçoar o maquinário, compõe com elas mais essa via.

A ciência trouxe à fábrica normas que precisavam ser seguidas, para que a produção ocorresse otimizadamente. Os trabalhadores tiveram de se adaptar à submissão a regras impostas de fora da produção, por indivíduos detentores do saber científico que não estavam ligados à produção diretamente. 
O trabalho exigido do trabalhador simplificou-se progressivamente, não apenas por seu papel de auxiliar da máquina, mas também devido à segmentação da produção.

Mas, para que seja afastada qualquer possibilidade de uma crítica romântica, é necessário deixar claro que a exploração do trabalhador não foi uma prerrogativa do capitalismo. Marx (1975a) também traz inúmeros relatos de exploração do trabalho artesanal pré-capitalista. Ocorre que, no capitalismo, a exploração acentuou-se na medida em que seus métodos foram aperfeiçoados, pari passu com a possibilidade de maior eficiência na produção.

A divisão do trabalho, por exemplo, não era algo exatamente novo, segundo Marx (1975a), pois a própria manufatura já contava com organização parecida, tendo inclusive fornecido à divisão do trabalho mecanizado sua base. Mas, embora tivesse algum fundamento na antiga divisão de trabalho do sistema manufatureiro, a moderna divisão, remodelada pelo capitalista com o auxílio da ciência, apresentava-se agora como “meio sistemático de explorar a força do trabalhador." (p.482). Do mesmo modo, a industrialização barateou as mercadorias, tornando-as mais acessíveis a um número maior de pessoas, que, entretanto, sendo mediadas pelo capital, revelam a falsa democratização desse processo, apesar das melhorias alcançadas.

A racionalização decompôs o trabalho e colocou homens para trabalhar como máquinas e a serviço delas. Para melhorar a produtividade, a subjetividade tem de ser eliminada (Crochik, 1990).

A dissociação entre ética e conhecimento (Crochik, 1990), resultante, dentre outros fatores, do próprio avanço do capital na 
sociedade, é uma expressão da liberdade com que a ciência se mercantiliza. Transformando seu saber em produto a ser vendido no mercado, fica livre para beneficiar a quem pagar.

Com tantas vantagens em favor da máquina para a aplicação capitalista, observa-se uma crescente exigência, para com o homem, de performance de máquina (Marx, 1975a). O homem vira um limite ao incremento da produção. Instrumento e trabalhador não apenas entram em confronto, mas em concorrência (Marx, 1975a).

No momento em que se observa que nesse confronto o trabalhador saiu perdendo, sendo sua imperfeição diante da perfeição da máquina um obstáculo ao capitalismo (Crochik, 1990), é preciso avaliar quais valores estão permeando a busca pela tecnologia - e, também, pelos testes psicológicos. Quais valores orientam a inversão do que deveria ser um fim (o homem) em um meio e o meio (a técnica) em um fim?

Nesse sentido, faz-se necessário ressaltar que, ao se analisar as características da produção capitalista, tenciona-se apontar para outro dado que transcende a aproximação entre testes e maquinário, que é a expansão da racionalidade produtiva para além da esfera da produção. A busca da rapidez, da eficiência e a "supressão" da subjetividade como forma de incrementá-las, a exigência de que o homem tenha um desempenho de máquina, a produção em série, o objetivo de baratear o custo para o consumidor, são todas funções que se expandem da esfera produtiva para as outras esferas sociais.

Essa expansão se apresenta nos testes psicológicos, que a fortalece. A lógica de produção e aplicação de testes é um processo 
racionalizado, similar à lógica de fábrica que decompõe o processo produtivo. A produção do conhecimento a partir do teste é segmentada, em linhas gerais, em elaboração, aplicação e correção. Embora interdependentes, um segmento é separado do outro. Os indivíduos envolvidos no processo mantêm um contato parcial com o teste, como o trabalhador tem um contato parcial com o produto final da linha de produção.

Ao assumir o lugar de objeto, cedendo à técnica o de sujeito, o homem desqualifica-se e fetichiza a técnica. "Fetiche" é um termo utilizado por Marx (1975b) para designar o fenômeno segundo o qual as mercadorias “parecem dotadas de vida própria, figuras autônomas que mantêm relações entre si e com seres humanos." (p.81).

A fetichização da mercadoria é decorrência do "caráter social do próprio trabalho que produz mercadorias." (Marx, 1975b, p.81). Ao mesmo tempo, a apresentação do produto do trabalho humano como mercadoria camufla a constituição social do trabalho, mostrando-o como independente da sua origem, encobrindo

\footnotetext{
“as características sociais do próprio trabalho dos homens, apresentando-as como características materiais e propriedades sociais inerentes aos produtos do trabalho; (...) [ocultando] portanto, a relação social entre os trabalhos individuais dos produtores e o trabalho total, ao refleti-la como relação social existente, à margem deles, entre os produtos do próprio trabalho." (p.81).
}

O mesmo se observa com relação à técnica que se apresenta como mercadoria. Os indivíduos atribuem a ela independência de sua 
origem social, promovendo-a a um status superior. Nos dias de hoje, com o advento da sociedade tecnológica e a valorização da informação e do conhecimento técnico como um bem, esse fenômeno apresenta um colorido próprio:

\begin{abstract}
"A ação dirigida de fora se torna mais freqüente e torna-se comum a procura de solução de problemas internos em técnicos especialistas, que minam assim a autonomia individual (...) A solução dos problemas individuais se localiza fora do indivíduo, em técnicas que anulam a fala do sujeito, ao confrontá-lo com critérios externos. A emergência da sociedade tecnológica transforma a qualidade em quantidade e a subjetividade em objeto técnico." (Crochik, 1990, p.119).
\end{abstract}

Mas, se para Marx (1975a), como vimos, o instrumento técnico em si mesmo não deve ser combatido por representar um avanço do homem diante da natureza, devendo-se partir para a crítica de sua aplicação capitalista, para Marcuse (1967), o instrumento já seria ele mesmo questionável.

Marcuse (1967) também concorda que a razão, e mais especificamente a tecnologia, possa promover maior felicidade ao homem, livrando-o do trabalho penoso e alienado, que passaria progressivamente a não ser seu encargo. Porém, para ele, a própria constituição dos instrumentais tecnológicos já deveria vir imbuída da finalidade de servir o homem, pacificando a existência.

Segundo ele, o objetivo último da racionalidade tecnológica deveria ser o homem, trabalhando como força emancipadora, levandoo para um domínio além das necessidades. Mas a racionalidade 
moderna contaria com um elemento irracional em seu interior. Se, por um lado, o nível do aparato técnico e econômico já garantiria ao homem maior liberdade ante as necessidades, por outro, ele encontrase cada vez mais subjugado a elas, por conta do próprio sucesso técnico e econômico atingido. O progresso da ciência e da técnica foi, para ele, transformado em instrumento de dominação, sendo a tecnologia a nova forma da ideologia.

Marcuse (1967) propõe uma reformulação das bases da técnica a partir de outra relação com a natureza que não a de aniquilamento, apontando a "pacificação da existência" como "alternativa histórica" para a superação da luta do homem com o próprio homem e com a natureza (p.36). A pacificação da existência pressuporia não a eliminação dessa luta, mas a superação de suas formas destrutivas. Em seu modo de ver, não é possível re-significar um aparato técnico que de antemão já estaria comprometido com outros fins que não a pacificação. A técnica, na sociedade capitalista, já traria em si mesma elementos insuperáveis de regressão, uma vez que é produto de uma organização social voltada para elementos regressivos:

\footnotetext{
“Organização para a paz é diferente de organização para a guerra; as instituições que serviram à luta pela existência não podem servir à pacificação da existência (...) a vida como um fim é qualitativamente diferente da vida como um meio." (p.36).
}

Desse modo, o alto desenvolvimento tecnológico, na visão de Marcuse (1967), poderia servir para perpetuar as formas de prisão do 
homem à esfera das necessidades ou poderia ser um meio de libertá-lo dela, mas não em sua forma atual. Como se verá adiante, essa concepção de Marcuse (1967) do papel da tecnologia parece estar em desacordo também com Horkheimer e Adorno (1991), para os quais os avanços tecnológicos carregariam em si a contradição da barbárie e da possibilidade de emancipação, sendo esta última possível já nos dias de hoje, o que denunciaria a irracionalidade em que a totalidade está envolvida.

Os apontamentos de Marcuse (1967), entretanto, são preciosos. Principalmente, ao mostrar como as concepções mentais decorrentes da racionalidade tecnológica transformaram a sociedade - e não apenas a esfera da produção - num imenso organismo administrativo, estando todas as diversas questões que a envolvem resumidas e tratadas como administrativas. Ele indica a paralisia da percepção do movimento dialético da história como um estado da unidimensionalização da sociedade do bem-estar social, na qual houve uma pretensa igualação de classes, a partir do momento em que as necessidades vitais foram, no geral, satisfeitas para todos e as classes subalternas puderam, nos países capitalistas centrais, ter o mesmo acesso "democrático" às mercadorias. Este fenômeno teria dissimulado a divisão social, neutralizando a opressão e enfraquecendo a luta de classes.

A ciência, nessa organização social, atua como a principal força, a fonte do saber objetivo e racional - pois a organização deve ser, antes de mais nada, objetiva e racional, como Marx (1975a) relatou ter ocorrido na produção moderna. 
Numa sociedade cercada pela administração total, como se refere Marcuse (1967), a vida tem aparência de livre, mas apenas na medida em que é livre a escolha de mercadorias. O que não se mercantilizou perde a força na vida social: "a comercialização total une esferas da vida antes antagônicas." (p.96). Mas, se outrora a coexistência destas contradições não foi sempre pacífica - Marx (1975a) reporta diversas lutas entre trabalhadores e capitalistas por causa da exploração a que os primeiros estavam submetidos -, Marcuse (1967) relata, em seu tempo, uma certa conciliação entre dominantes e dominados, tanto no plano concreto como no plano das idéias:

“... a dimensão 'interior' da mente, na qual a oposição ao status quo pode criar raízes, é desbastada. A perda dessa dimensão, na qual o poder de pensamento negativo - o poder crítico da Razão - está à vontade, é a contrapartida ideológica do próprio processo material na qual a sociedade industrial desenvolvida silencia e reconcilia a oposição." (p.31)

O controle social dar-se-ia então pela tecnologia e ancorar-se-ia agora nas “novas necessidades que ela produziu." (Marcuse, 1967, p.30).

A existência tende a tornar-se unidimensional, plana, sem contrastes, conflitos ou diferenças, desde a esfera pública até os recantos mais privados do indivíduo - "os controles tecnológicos parece serem [sic] a própria personificação da Razão para o bem de 
todos (...) a tal ponto que toda contradição parece irracional." (Marcuse, 1967, p.30).

Marcuse (1967) mostra de forma clara a relação entre o pensamento e as condições concretas de existência. De acordo com ele, o desvanecimento do poder negativo da Razão, que culmina no totalitarismo da racionalidade tecnológica e está ligado à reconciliação de opostos no pensamento, corresponde, por sua vez, a uma aparência de reconciliação de opostos na experiência: a perda da negação da afirmação (bidimensionalidade do pensamento) seria um reflexo de uma realidade também unidimensional. O enfraquecimento do poder negativo, aliado ao poder que a ciência conquistou em nossa sociedade como força produtiva e ideológica, leva muitas vezes a uma aceitação incondicional dos resultados por ela apresentados ou mesmo dos instrumentos empregados.

Conforme Marcuse (1967), na filosofia clássica como um todo, o conhecimento não estava dissociado do valor. A busca da verdade, tarefa da Razão (busca do Ser), era uma busca ética, uma vez que o Não-Ser era também a destruição e Ser era melhor que seu pólo negativo, o Não-Ser. Essa tensão no pensamento dava-se porque se fundava, segundo o autor, numa realidade que também era tensa, bidimensional e os contrastes seriam condições ontológicas.

A diferença fundamental entre um projeto pré-tecnológico e tecnológico de Razão não é a presença ou a ausência de dominação, pois “a racionalidade pré-tecnológica e tecnológica (...) são ligadas pelos elementos do pensamento que ajustam as regras do pensamento às regras do controle e da dominação." (Marcuse, 1967, p.138). A 
diferença estaria no modo como se dá, nos dois casos, a subordinação às necessidades vitais e a organização das "novas modalidades de liberdade e não-liberdade que correspondem a essa organização." (p.130). Em seu formato contemporâneo, seria preciso investigar como e por meio de que se dá a dominação.

Um ponto comum, portanto, nas análises de Marx (1975a) e de Marcuse (1967) é que a máquina, em seu uso capitalista, não veio para aliviar o homem de um trabalho penoso e arriscado, mas tãosomente para aumentar os ganhos do capitalista. Embora ela pudesse libertar o homem do trabalho alienado, o que terminou promovendo foi um aprofundamento da desumanidade. No entanto, a Razão, como base da técnica, promove a barbárie tanto quanto pode superá-la (Adorno, 1965; Horkheimer e Adorno, 1973a; 1973b; 1991). Para uma inserção maior deste ponto, será útil neste momento compreender o movimento histórico da Razão na cultura ocidental.

\section{2 - A Razão como base da técnica}

Antes de se aprofundar este tópico, no qual Horkheimer e Adorno (1991) serão a base, é importante que se volte mais detalhadamente para o conhecimento dos fundamentos do positivismo, sistema filosófico que embasa a ciência moderna e ao qual se referirá muitas vezes ao longo deste trabalho.

Conforme Lalande (1996), o termo positivismo significa: 
“A. No sentido próprio: $1^{0}$, conjunto das doutrinas de Auguste Comte, tal como foram expostas essencialmente no Curso de filosofia positiva (1830-1842); no Discurso sobre o espírito positivo (1844); no Catecismo positivista (1852); no Sistema de política positiva (18521854) $(\ldots)$

“B. Dá-se por extensão a designação de positivismo a doutrinas que se ligam à de Auguste Comte ou que se Ihe assemelham, ainda que, por vezes, de um modo bastante longínquo, e que têm por teses comuns que só o conhecimento dos fatos é fecundo; que o modelo da certeza é fornecido pelas ciências experimentais; que o espírito humano, tanto na filosofia como na ciência, só pode evitar o verbalismo ou o erro na condição de se ater incessantemente ao contato com a experiência e de renunciar a todo e qualquer a priori; por fim, que o domínio das 'coisas em si' é inacessível, que o pensamento não pode atingir senão relações e leis. [ grifos nossos]" (p.824-5).

Grosso modo, o positivismo é a doutrina que baliza a ciência moderna, para a qual a verdade reside no imediatamente dado, no fato. Para alcançá-la, o positivismo dispõe de um método. Se o conhecimento não é submetido ao método ou se não resiste a suas categorias lógicas, não tem estatuto de verdade para a ciência.

Historicamente, o positivismo buscou a afirmação da realidade por meio da afirmação do dado imediato, ao contrário de outros sistemas que, antes de aceitarem o dado como uma verdade única, o problematizaram.

Cabem aqui algumas considerações. Essas explanações acerca do método positivista não podem obscurecer um fenômeno importante 
que é a "positivização" das relações sociais, algo que transcende o sistema filosófico em si e será considerado neste capítulo, a partir da discussão do conceito de esclarecimento, segundo Horkheimer e Adorno (1991).

O positivismo moderno radica-se na filosofia positiva, que foi, de acordo com Marcuse (1988), uma resposta ao racionalismo da época, especialmente o francês e o alemão, tendo como principal alvo o sistema hegeliano, que ficou denominado de filosofia negativa, dada sua característica crítica:

\footnotetext{
“Hegel tinha considerado a sociedade e o estado como o trabalho histórico do homem, e os tinha interpretado sob o aspecto da liberdade; opondo-se a isto, a filosofia positiva estudava as realidades sociais segundo os modelos da natureza e sob o aspecto da necessidade objetiva. A independência dos fatos comuns devia ser preservada e o raciocínio devia ser dirigido pela aceitação do dado. Desta maneira, a filosofia positiva visava a neutralizar o processo crítico implicado na 'negação' filosófica do dado, e a restituir aos fatos a dignidade do positivo." (Marcuse, 1988, p.298).
}

O que o moderno positivismo guardaria ainda da filosofia positiva é, essencialmente, "a convergência do pensamento para os fatos e a elevação da experiência à posição de meta do conhecimento." (Marcuse, 1988, p.298).

O emprego do termo "positivismo", em seu significado moderno, designando um método de ciência, deve-se a Saint-Simon (Marcuse, 1988). O nome de Auguste Comte aparece relacionado à história do 
positivismo pelo fato de ele haver sido um grande entusiasta do novo método, expandindo-o das ciências físicas e biológicas para a teoria social. Há que se ressaltar que Comte, indubitavelmente um marco no desenvolvimento do positivismo, foi, no entanto, antes um organizador e sistematizador das idéias do que seu fundador propriamente dito, como muitas vezes é referido.

A sociedade, de acordo com o positivismo, passaria a ser estudada como se fosse a natureza, e a ciência seria o campo em que os julgamentos ficariam suspensos. Os dados não precisariam ser interpretados ou criticados, mas compreendidos e organizados (Marcuse, 1988). A posição de Comte, descrita por Marcuse (1988), de resignação e conformismo ante a realidade, seria frontalmente contrária à combatida filosofia hegeliana, o que ele ironicamente explicita nesta passagem:

“... a sociologia positiva deve se ocupar com a investigação dos fatos, em vez de se ocupar com ilusões transcendentais; com conhecimento utilizável, em vez da contemplação ociosa; com a certeza, em vez da dúvida e da indecisão; com a organização, em lugar da negação e da destruição." (Marcuse, 1988, p.310).

A complacência e o convite à aceitação do dado imediato tal como é, possibilitados pelo método positivista, fez dele uma saída política diante da revolução que se teria anunciado, segundo Marcuse (1988), com a filosofia negativa de Hegel.

Mas nem todo o movimento positivista foi conservador. Marcuse (1988) ressalta o veio revolucionário do positivismo do século XVIII, 
num momento em que voltar-se para o fato era opor-se ao ideário religioso e metafísico que dava suporte ao Antigo Regime.

O positivismo é, portanto, um grande marco na história não apenas do pensamento ocidental, mas da própria humanidade; basta atentar para o assoberbado crescimento tecnológico que alcançou, mudando as feições do mundo a passos largos. Poder-se-ia dizer, entretanto, que ele seja o aperfeiçoamento de certas características da razão que já se anunciavam há tempos.

A razão foi sempre um meio de o homem enfrentar seu subjugo diante das forças da natureza. Assim surge a técnica, tendo o medo da natureza por propulsor e a dominação da natureza por objetivo. Aprendendo a manipular a natureza, os homens buscaram dominá-la. Conforme afirmam Horkheimer e Adorno (1991), o que eles desejavam do conhecimento eram subsídios para subjugar e manipular a natureza, investindo-os da posição de senhores.

Desde o início, o objetivo da ciência era o de fabricar instrumentos que dessem conta do domínio da natureza. É na operacionalização de formas eficientes de dominação da natureza que se encontra sua razão de ser (Crochik, 1990; Silva, 1997). Mas o objetivo da eficiência é garantir a sobrevivência, sendo uma marca do saber e não apenas do saber científico (Silva, 1997).

Bacon defendia que o conhecimento, para avançar em relação ao passado, devia se voltar apenas à busca da eficácia do procedimento e não ser a pura e simples busca da verdade, relegada como certa corrupção: "poder e conhecimento são sinônimos." (Bacon apud Horkheimer e Adorno, 1991, p.20). Bacon se referia ao uso da 
razão para que se pudesse então exercer poder sobre a natureza, que seria colocada a serviço do homem.

O que talvez não estivesse incluído no projeto era o fato de que a razão pudesse também servir à desrazão. A contradição explicitada por Marx (1975a) com relação ao maquinário, que poderia aliviar o sofrimento humano mas mergulhou o homem mais profundamente nele, e por Marcuse (1967), para o qual a tecnologia poderia cumprir os fins de libertação do homem se viesse imbuída deste objetivo, insere-se, a nosso ver, no próprio movimento do esclarecimento, exposto por Horkheimer e Adorno (1991). Neste, evidencia-se a dialética do esclarecimento, ou seja, o próprio movimento da razão humana que visou libertar o homem da dominação da natureza e no entanto o aprisionou a ela. O mesmo caminho buscado para a libertação é o da prisão.

A dialética do esclarecimento já estaria registrada na Odisséia, de Homero, evidenciando que muito antes da ascensão da classe burguesa ou do movimento iluminista o homem burguês já se prenunciava, "prototipizado" em Ulisses (Horkheimer e Adorno, 1991). Em Ulisses, a relação entre trabalho, razão e dominação mostra sua característica burguesa, especialmente no modo como ele, por meio da razão astuta, faz do trabalho um instrumento para dominar a irracionalidade e a indiferenciação encarnadas nas Sereias e ao mesmo tempo negar a promessa de felicidade que trazem, como será retomado mais adiante neste capítulo.

O que faz com que o caminho escolhido aprisione, em vez de libertar, é o fato de que, em lugar de domar as forças da natureza 
interna e externa, apaziguando-as, o esclarecimento rompeu com a natureza ao negá-la, para negar o medo, resultando no retorno da natureza em forma de barbárie: "toda tentativa de romper as imposições da natureza rompendo a natureza, resulta numa submissão ainda mais profunda às imposições da natureza." (Horkheimer e Adorno, 1991, p.27).

Assistindo a sua própria subsunção à natureza, a civilização entra no antigo circuito de repetição e ritmo alienados, que agora a própria cultura, que se mostra como elemento indiferenciador do homem, promove. Para escapar da submissão, o homem submeteu as forças naturais a seu comando por meio da razão.

Ao negar a natureza como forma de negar o medo, fica negada também a relação de dominação entre natureza e homem. Uma das formas de negação do horror mítico foi o afastamento do desconhecido; para isso, é preciso negar o que se encontra fora do conhecido. E então, "nada mais pode ficar de fora, porque a simples idéia do 'fora' é a verdadeira fonte de angústia." (Horkheimer e Adorno, 1991, p.29). Ao presumir um contato apenas com o que já consegue dominar, eliminando o novo, o esclarecimento crê estar livre dos elementos que trarão de volta a dominação negada. É nesse sentido que os autores afirmam: "a pura imanência do positivismo, seu derradeiro produto, nada mais é do que um tabu, por assim dizer, universal." (p.29).

A relação do homem com a natureza apresenta-se como uma relação de poder; de opressão e submissão, na trajetória do esclarecimento, de escolha "entre submeter-se à natureza ou 
submeter a natureza ao eu." (Horkheimer e Adorno, 1991, p.43). As relações de opressão e submissão do homem com a natureza são um parâmetro também das relações entre os homens. O homem aprendeu a submeter a natureza ao eu e o eu aprendeu a submissão ao poder. Se o poder vem do saber, a dominação constituiu uma finalidade em si mesma e “o desenvolvimento da máquina já se converteu em desenvolvimento da maquinaria da dominação." (p.46).

Na magia, a relação de poder entre o homem e a natureza é assentada diferentemente: “a dominação ainda não é negada, ao se colocar (...) como a base do mundo que a ela sucumbiu." (Horkheimer e Adorno, 1991, p.24). Por meio da mimese com o mundo, o feiticeiro cumpre seus fins submetendo-se ao poder invisível. Para afastar o mal, o feiticeiro entra em contato com o mal, mimetiza-se com ele e volta ao mundo de sua experiência anterior, fixando "a transcendência do desconhecido em face do conhecido e, assim, o horror como sacralidade" (p.29). Na mimese, a relação entre objetivo e subjetivo está em movimento e impregnada de sentido. O feiticeiro ainda não se declarou à "imagem e semelhança" (p.29) do poder invisível, investindo-se da armadura senhoril ante as forças da natureza. Para dominar o horror, ele se identifica com ele e não o elimina.

Mesmo na metafísica, que declarou a falsidade dos mitos, era possível "entrever a injustiça da ordem existente pelo menos através da incongruência do conceito e da realidade" (Horkheimer e Adorno, 1991, p.35). Esta incongruência é o que não mais está podendo existir nos dias de hoje. 
A ciência moderna estrutura-se na identificação do "animado ao inanimado" (Horkheimer e Adorno, 1991, p.29), na negação do subjetivo no objetivo, abstraindo-se do sentido, afastando-se do emaranhado e do desconhecido. Como não pensa seus elementos regressivos, aprofunda-se ainda mais na falta de sentido.

De acordo com Marcuse (1967), o método científico tem algum fundamento na tensão entre aparência e realidade. Mas é na relação sujeito-objeto que o sujeito, ao ser puramente um observador, mensurador, calculador, experimentador, um ente externo à relação, torna-se abstrato e passa a projetar e definir o objeto abstrato. Segundo Max Born (apud Marcuse, 1967), o conhecimento não está no objeto em si, mas na relação do objeto com outras coisas.

A intimidade entre sujeito e objeto enfraquece-se e acaba desqualificada pelo "eu que não pode se perder na identificação com o outro." (Horkheimer e Adorno, 1991, p.25). O conhecimento que atinge verdadeiramente o objeto, que não o anula e não se petrifica, não é reconhecido como saber. A natureza vira matéria à parte e

\footnotetext{
“as múltiplas afinidades entre os entes são recalcadas pela única relação entre o sujeito doador de sentido e o objeto sem sentido, entre o significado racional e o portador ocasional do significado." (p.25).
}

O método lógico-matemático, fundamental para a ciência moderna, também tem raízes históricas. A identificação do universo com o uno aparece como uma tentativa de livrar o homem do horror, tendo sua busca se saciado, no pensamento ocidental, com a lógica 
formal (Horkheimer e Adorno, 1991). A lógica formal aristotélica pode ser considerada a ancestral da racionalidade tecnológica. Mas, quando ela surge, o pensamento filosófico já está familiarizado com o crescendum de abstrações, em que o "conteúdo material é neutralizado" (Marcuse, 1967, p.137) e os conceitos, "bem definidos em seu alcance e função (...) se tornam instrumentos de predição e controle" (p.137). A Metafísica de Aristóteles aparece como um certo divisor de águas na busca da eficiência, vinculando o conceito ao controle, sendo um passo importante na neutralização das contradições no plano do pensamento (Marcuse, 1967).

Segundo Horkheimer e Adorno (1991), na busca do uno, a lógica formal foi a grande escola congregadora, fornecendo o modo de enquadrar o mundo ao cálculo: não obstante "as diferentes escolas interpretassem de maneira diferente os axiomas, a estrutura da ciência unitária era sempre a mesma." (p.22). Como uma grande identificadora do real, a lógica representa uma vitória na capacidade de tradução dos fenômenos de forma unívoca, ao codificá-los matematicamente, em oposição à "plurivocidade do pensamento mítico." (p.42). Esta capacidade de unificar o fenômeno foi de tal sorte avassaladora que o número logo assumiu seu papel como "o cânon do esclarecimento." (p.22). Merecidamente, pois ela oferece a possibilidade de equalização ou, em outras palavras, de identificação de qualquer objeto com outro, uniformizando-os.

Equalizados, reduzidos a números, os fenômenos perdem sua dimensão qualitativa. Ao se universalizarem as particularidades e idiossincrasias dos seres, ganha-se maior poder de manipulação sobre 
eles, pois tornam-se mais eficientemente apreensíveis. Por outro lado, perde-se o que havia neles de mais particular, sua diferenciação, enfim, seu nome, que cede à identidade de tudo com tudo, concretizando um dos mais arcaicos horrores do homem, aquilo do qual se tentou a fuga mediante tantos esforços da razão, a indiferenciação (Horkheimer e Adorno, 1991).

A ciência moderna, por meio de seu método de conhecimento, pressupõe ao objeto categorias a priori. Quando o procedimento matemático equaciona o problema e coloca os elementos desconhecidos como incógnitas da equação, ele os torna conhecidos antes mesmo de conhecê-los, já os enquadrando para ser aquilo que a equação permitir. Com isso, é como se passasse a apreender um falso objeto, o objeto que coube ao método formatar; modifica-se o objeto para que ele se encaixe no método, já que, "de antemão, o esclarecimento só reconhece como ser e acontecer o que se deixa captar pela unidade." (Horkheimer e Adorno, 1991, p.22).

O dado imediato não é um "em-si", mas uma realidade histórica e social que o método desconsidera, por definição, ao expurgar contradições:

“... a análise se abstrai do negativo, daquilo que é alheio e antagônico (...)

"A filosofia positivista monta um mundo auto-suficiente todo seu, fechado e bem protegido contra a entrada de fatores externos perturbadores (...) De um ou de outro modo, todos os predicados possivelmente significativos são prejulgados. O julgamento prejulgador 
(...) uma vez aceito, constitui um a priori empírico que não pode ser transcendido.

“Mas essa aceitação radical do empírico viola o empírico, porque nele fala o indivíduo mutilado, 'abstrato', que só experimenta (e expressa) aquilo que lhe é dado (dado em sentido literal), que dispõe apenas dos fatos e não dos fatores (...) Em virtude da repressão real, o mundo experimentado é o resultado de uma experiência restrita, e a limpeza positivista da mente põe esta em consonância com a experiência restrita." (Marcuse, 1967, p.173).

O método fornece um conhecimento apriorista porque não tem instrumental para trabalhar com a negatividade. Para isso,

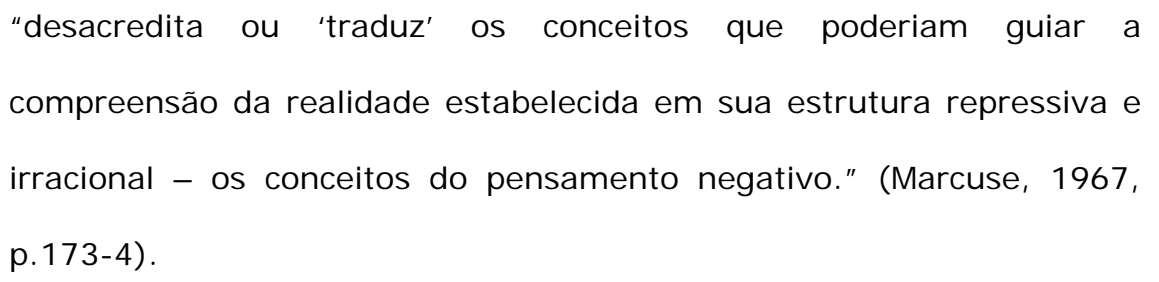
compreensão da realidade estabelecida em sua estrutura repressiva e irracional - os conceitos do pensamento negativo." (Marcuse, 1967, p. 173-4).

O objeto da dominação, mutilado pelo método, reduz-se a substrato dessa dominação, não porém sem um custo, como afirmam Horkheimer e Adorno (1991), comentando Kant (Crítica da Razão Pura):

\footnotetext{
“Não há nenhum ser no mundo que a ciência não possa penetrar, mas o que pode ser penetrado pela ciência não é o ser. É o novo (...) que o juízo filosófico visa e, no entanto, ele não conhece nada de novo, porque repete tão-somente o que a razão já colocou no objeto." (p.38).
} 
Da mimese o homem ainda não se encontra livre; na magia era o animado que ia ao encontro do inanimado, mas na ciência "a ratio, que recalca a mimese, não é simplesmente seu contrário. Ela é a própria mimese: a mimese do que está morto." (Horkheimer e Adorno, 1991, p.62)

A quantificação das qualidades supõe e envolve, segundo Marcuse (1967), uma determinada visão de mundo, uma determinada vivência do Lebenswelt ${ }^{1}$. Por mais descobertas que se façam no campo científico, umas se superando às outras, não se rompe, segundo ele, com o universo histórico estabelecido. A ciência continuaria a promover e expandir as mesmas "formas institucionalizadas de vida" (p.159), porque não consegue transcender o próprio Lebenswelt. A ciência moderna, por reproduzir incansavelmente o Lebenswelt e limitar-se a ser a técnica de um Lebenswelt, prendendo-se a ele para proferir seus conhecimentos, colabora para a manutenção do mundo tal como é. O que não significa que a técnica, justo por ser a reprodução do Lebenswelt, não seja importante para o homem, sua sobrevivência e melhora nas condições práticas de vida. A crítica está em que se possa perceber que o conhecimento não pode se limitar a isso, colocando em risco, inclusive, a própria melhoria de vida alcançada.

Se preso ao factual, à camada superficial do real, o discurso científico é um discurso que se atém à aparência das coisas. Ratificase assim a Ciência como conhecimento a-histórico. A história, na

1 Termo usado por Husserl, citado em Marcuse (1967), que se refere ao "mundo da prática" (p.157). 
vertente frankfurtiana, traz a finitude como um elemento presente, e não negado o tempo inteiro. O número, por outro lado, sendo "a figura mais abstrata do imediato" (Horkheimer e Adorno, 1991, p.39), torna esse a-histórico e associal.

O que parece ser a vitória da razão sobre a natureza, a vitória da objetividade, "a submissão de todo ente ao formalismo lógico" revela seu custo na "submissão obediente da razão ao imediatamente dado." (Horkheimer e Adorno, 1991, p.39).

O conhecimento não está meramente na percepção, no cálculo e na classificação, mas "na negação determinante de cada dado imediato." (Horkheimer e Adorno, 1991, p.39). No entanto, quando a dominação da natureza pelo trabalho tira o lugar da influência por assimilação (Horkheimer e Adorno, 1991) perde-se a maior pretensão do pensamento, que é pensar as relações, pensar o desconhecido mesmo que não se tenha uma resposta a respeito para ser fornecida e, sobretudo, pensar a si mesmo.

A abstração é uma ferramenta do esclarecimento. Esta ferramenta pressupõe o distanciamento na relação do sujeito com o objeto, que está ligada ao distanciamento “em relação à coisa, que o senhor conquista, através do dominado" (Horkheimer e Adorno, 1991, p.27-8), qual Ulisses controlando suas terras não pessoalmente, mas por meio de seus servidores.

No décimo segundo canto da Odisséia, Ulisses confronta-se com a sedução de se perder nas potências da dissolução, objetivadas nas Sereias. Chamou a atenção de Horkheimer e Adorno (1991) não apenas o modo sui generis pelo qual Ulisses malogra o canto das 
Sereias, como também o fato de que o herói termina caindo no percurso que o levará ao confronto com elas. O modo peculiar como ele consegue superar o perigo é uma metáfora viva do modo burguês de lidar, em última análise, com o horror mítico.

Ulisses sabe que, se ouvir o canto, não conseguirá resistir. Então, pede a seus companheiros que o amarrem ao mastro do navio para que, ao ouvir, não se entregue. Os companheiros, por outro lado, precisam fazer o navio sair do lugar e, portanto, não podem ser acorrentados. Mas, para que não se percam também, Ulisses veda-Ihes os ouvidos com cera, de modo que continuarão a executar a tarefa sem perigo, pois o som do canto não pode atingi-los. Ulisses ouve mas não pode se entregar; os outros não se entregam porque não ouvem.

Ele sabe que não deve pôr à prova sua resistência, então apela para sua razão para que o ajude a superar a desrazão e a felicidade proibida. Ulisses consegue salvar a si e aos companheiros do canto das Sereias perdendo-se nele. Uma perda, porém calculada, astuta, que, ele sabe, não o perderá. Nisto consiste seu elemento burguês, observam Horkheimer e Adorno (1991), na capacidade de, por meio da razão, livrar-se dos poderes míticos malogrando sua repetibilidade e, assim, destruindo-os. O mito só tem sentido na repetição a que está obrigado. Uma vez que se a vença, vence-se o mito; ele sai de sua rota habitual e perde o sentido de ser.

Essa passagem consiste, segundo os autores, numa metáfora da alienação em face da conquista, conseqüência da dominação por meio do trabalho mediado. Acorrentado em decorrência de sua própria racionalidade, Ulisses ouve o chamado irresistível, mas, sabendo da 
irresistibilidade, arma-se, fechando-se. Nada amarra os marinheiros do barco, apenas a razão de Ulisses, que cuidou para que a sedução passasse ao largo de seus homens.

Foi se separando submissão do poder tanto na esfera do pensamento como na esfera social. Tanto em uma como na outra, quem se submete tem acesso à coisa mas não ao comando; quem comanda não tem acesso à coisa.

O esclarecimento acaba refletindo uma opressão real do mundo, exprimindo "o movimento real da sociedade burguesa como um todo sob o aspecto da encarnação de sua Idéia em pessoas e instituições." (Horkheimer e Adorno, 1991, p.14). O poder sobre a natureza se estendeu como poder sobre os próprios homens. Na esfera conceitual, a dominação fundamenta-se nesta dominação do real. A dominação se expressa de forma una, por meio do dominador.

A vitória sobre o mito fortalece Ulisses, porquanto cunhada em seu próprio sofrimento. A identificação entre este eu fortalecido e o projeto do esclarecimento foi grande: "o eu, que aprendeu a ordem e a subordinação com a sujeição do mundo, não demorou a identificar a verdade em geral com o pensamento ordenador." (Horkheimer e Adorno, 1991, p.28).

A força irracional foi estigmatizada como aniquiladora, como um caminho que necessariamente levaria à indiferenciação (Horkheimer e Adorno, 1991). Por esse motivo, as manifestações da irracionalidade foram sempre contidas e o prazer foi dissociado não só do trabalho, mas das várias atividades humanas consideradas decentes. 
Não obstante os cantos de sereias pelo mundo afora, o eu não pode se misturar, devendo manter-se coeso a todo custo. A dominação se dá pelo trabalho e o trabalho não pode se identificar com nada que remeta àquela dissolução primal da qual quer se livrar:

\begin{abstract}
“O eu integralmente capturado pela civilização se reduz a um elemento dessa inumanidade, à qual a civilização desde o início procurou escapar. Concretiza-se assim o mais antigo medo, o medo da perda do próprio nome. Para a civilização, a vida no estado natural puro, a vida animal e vegetativa, constituía o perigo absoluto (...) a idéia de recair neles [comportamento mítico, mimético e metafísico, que foram considerados superados] estava associada ao pavor de que o eu revertesse à mera natureza, da qual havia se alienado com esforço indizível e que por isso mesmo infundia nele indizível terror." (Horkheimer e Adorno, 1991, p.42).
\end{abstract}

Sem ter alcançado liberdade ante o horror, o homem ainda tem sua vida e pensamento rondados por ele, nas mais diversas formas. Não obstante o esclarecimento tenha destruído, sucessivamente, aquilo que o remete ao horror, como os "comportamentos mimético, mítico e metafísico" (Horkheimer e Adorno, 1991, p.42), ele reapareceu na filosofia por meio do "conceito". O conceito já seria, desde os primórdios da civilização, resultado da dialética, em que “cada coisa só é o que é tornando-se o que ela não é." (p.29). Mas, assim como a magia e o mito, o conceito não pode livrar os homens do medo, pois eleva-se a partir da petrificação do grito de horror. 
O enfraquecimento ou mesmo destruição do conceito direciona a ciência para a busca cada vez maior da verdade nos dados. Por isso a necessidade de pensar as técnicas que se voltam ao dado imediato quanto a seu valor conceitual. A ausência de conceitualização indicaria não apenas uma reverência grande e de certo modo cega ao factual, que se tomaria como parâmetro de si próprio, mas também a presença de um movimento histórico de afastamento em relação à possibilidade de se transcender o universo conhecido por meio da aproximação com o que se desconhece.

Mas, muito embora o apelo a um recurso que se volte ao imediatamente dado possa estar servindo a propósitos que de uma maneira ou outra estejam colaborando não com a emancipação do homem, mas com seu aprisionamento, nem por isso deixa de neles residir a possibilidade de liberdade.

A razão é um instrumento humano que permite ao homem ter consciência, mas que permite também a barbárie. Quando a razão é repetição, ela perde seu caráter emancipatório e a cultura passa a ser tão repetitiva quanto a natureza. Embora o pensamento formal seja importante para a civilização, ele próprio está servindo para a regressão social. Como explicita Crochik (1998a), é papel da cultura proteger o homem dos perigos da natureza. Posto que o homem também seja natureza, prossegue ele, é função da cultura protegê-lo de si próprio, o que ela faz ao regular a relação entre os homens.

Quando o homem nega a natureza de que também faz parte, ele se perde de si. A natureza negada se volta contra ele como barbárie. No entanto, “reconhecer (...) a presença da dominação dentro do 
próprio pensamento como natureza não reconciliada" (Horkheimer e Adorno, 1991, p.51) é condição necessária para superar a barbárie.

A ênfase na produção e as relações de equivalência tanto na ciência como no capital dominam nossa sociedade (Horkheimer e Adorno, 1991). A razão passa a ser mediada pelo capital, bem como a servir às forças produtivas, o que não apenas mostra, como se viu, que não é neutra, mas que, ao fazer parte das relações de produção, passa a ser importante para a manutenção do mundo tal como ele é.

A questão não se resume à técnica em si mesma. Nas palavras de Horkheimer e Adorno (1991), “a técnica é tão democrática quanto o sistema econômico com o qual se desenvolve." (p.20). Para entender a inserção da técnica em nossa cultura, estamos levando em conta a própria coisificação do homem no processo técnico, considerando que “no trajeto da mitologia à logística, o pensamento perdeu o elemento da reflexão sobre si mesmo e hoje a maquinaria mutila os homens mesmo quando os alimenta." (p.48).

Essas e outras considerações serão aprofundadas no Capítulo 5. Vamos nos dirigir, no momento, ainda que brevemente, à conceptualização de ideologia para a teoria crítica e, em seguida, à explicitação da contradição do entendimento do indivíduo como mônada presente na psicanálise. 


\section{3 - I deologia e "monadologismo" na Teoria Crítica}

De acordo com Horkheimer e Adorno (1973c), a ideologia é aparência socialmente determinada. Aparência porque ela não é a realidade, apontando uma identidade entre realidade e coisa que não existe. Determinada porque se projeta da realidade e a mantém. É desta forma que ela se expressa dizendo que as coisas são e não estão assim. Portanto, o discurso ideológico é verdadeiro ao falar sobre a superfície do real e falso porque está falando só sobre ela com a pretensão de estar falando sobre o real.

Essa concepção de ideologia, entretanto, mostra-se fundamentalmente anacrônica nos dias de hoje, em que a realidade tornou-se ideologia de si mesma ao julgar a si como verdade.

A noção de ideologia é datada:

\footnotetext{
“Todos os motivos conceptuais que provêm da pré-história do conceito de ideologia pertencem a um mundo em que ainda não existia uma sociedade industrial desenvolvida e quase não se duvida de que a liberdade seria obtida, efetivamente, com a realização da igualdade formal dos cidadãos." (Horkheimer e Adorno, 1973c, p. 190).
}

Historicamente, a conceptualização da ideologia ancora-se, segundo esses autores, na crença burguesa, que é seu próprio fundamento, de que seja "suficiente pôr a consciência em ordem para que a sociedade fique ordenada." (p.191). 
Várias teorias tentaram compreender a ideologia ao longo da filosofia e da sociologia e, hoje, seu conceito e função necessitam ser repensados à luz das transformações estruturais ocorridas na sociedade (Horkheimer e Adorno, 1973c). Desse modo, não se deve estudar as ideologias em si, mas o movimento histórico que levou as levou a mudar, para justamente poder captar o movimento do objeto. Eles analisam o caso da ideologia fascista: seus enunciados pouco racionais não dizem muito a respeito de suas idéias além de atestar a própria irracionalidade. A realidade da ideologia do fascismo não está em seus enunciados, mas deve ser buscada nas transformações estruturais da sociedade e nas configurações psíquicas que aderem a elas.

Historicamente falando, se antes, quando da ascensão da burguesia ou do advento da Revolução Industrial, a ideologia oferecia alguma possibilidade de transcendência do real, se era a crença em um certo ideário, hoje ela simplesmente espelha o real em toda sua irracionalidade (Horkheimer e Adorno, 1973c). Ainda de acordo com esses autores, a ideologia tem de ser vista com a relação que mantém com a própria realidade e, contemporaneamente, a realidade tornouse ideologia de si mesma, pelas escassas possibilidades de se pensar de outra forma. Num certo sentido, a crença num ideário deu lugar à sobrevivência.

A dialética entre verdade e falsidade, própria da ideologia, perde o sentido, em nossos dias, ante a hegemonia da falsidade. A ideologia não é mais um corpo de idéias que fala da realidade, encobrindo a dominação, pois a dominação consegue se perpetrar mesmo 
mantendo-se transparente. O poder hoje é menos mediado. A sociedade não precisa mais de ideologia como justificação porque a opressão está prescindindo de justificação para se reproduzir. O desvanecimento do pensamento, a domesticação dos espíritos e o conformismo falam por ela, a dominação introjetada no âmago dos homens garante a docilidade e a submissão ao status quo.

O homem da sociedade contemporânea pós-industrial encontrase subjugado a uma vida regida por sua herança selvagem indomada que retorna como barbárie, enfrentando espaços sociais cada vez mais estreitos às manifestações do particular, engolfado no capitalismo de oligopólios.

A falsa consciência de hoje está adaptada à realidade por meio dos produtos da indústria cultural, da produção artificial de consciência de um indivíduo cada vez mais frágil, socializado diretamente pelo todo por intermédio dos modelos oferecidos para identificação por essa indústria cultural (Horkheimer e Adorno, 1973c). Ídolos do cinema, dos esportes, da TV, heróis de filmes, cantores, são todos produtos ofertados pela indústria cultural e servem como modelos de conduta (Horkheimer e Adorno, 1973c). O indivíduo progressivamente amparase mais nos referenciais externos, buscando na totalidade a autoridade que não encontra no particular:

“Temos aqui a produção sintética da identificação das massas com as normas e condições que regem anonimamente a indústria cultural ou que a propagam - ou ambas. Qualquer voz discordante é objeto de 
censura e o adestramento para o conformismo estende-se até às manifestações psíquicas mais sutis." (p.202).

"Converte-te naquilo que és" (Horkheimer e Adorno, 1973c, p.202) parodia, segundo os autores, a tendência da ideologia da cultura de massa, que destrói toda a perspectiva de transcendência e de crítica, uma vez que ser aquilo que se é aniquila a imanência e limita a realidade tal como está.

Se o pensamento está na negação, em nosso tempo é difícil pensar. Como então apontar a irracionalidade de alguma idéia ou teoria, se é o próprio ato de pensar que está conformado e adaptado?

Nesses termos, a crítica ideológica perde o poder de fogo, já que “a crítica ideológica, como confronto da ideologia com a sua verdade íntima, só é possível na medida em que a ideologia contiver um elemento de racionalidade com a qual a crítica se esgote." (Horkheimer e Adorno, 1973c, p.191). Como a realidade converteu-se em ideologia e a ideologia em mentira manifesta, não há com que a crítica racional se relacionar no discurso ideológico contemporâneo.

A ideologia em nossos dias espelha o real e "não é um envoltório mas a própria imagem ameaçadora do mundo." (Horkheimer e Adorno, 1973c, p.203).

No sentido da perda da racionalidade da ideologia, somos herdeiros da ideologia fascista, cujos elementos racionais não são agrupáveis nem criticáveis, do ponto de vista da crítica ideológica. Para estudar o fascismo, ou qualquer fenômeno ideológico irracional, é preferível "analisar a que configurações psicológicas querem se referir 
para servirem-se delas; que disposições desejam incutir nos homens com suas especulações." (Horkheimer e Adorno, 1973c, p. 192).

Adorno mostra que Freud tem uma leitura de indivíduo que se constitui como mônada. Estudar a mônada já seria entender melhor as configurações que sustentam a ideologia. Nesse sentido está também a importância dos métodos tipológicos na pesquisa, como os testes psicológicos, o que será aprofundado mais adiante.

A conceptualização da mônada faz parte da metafísica de Leibniz, sendo a menor substância existente no universo. A mônada não nasce nem morre, não tem portas nem janelas e não sofre interferência de outra mônada do mesmo nível, mas de superiores. Cada mônada representa uma partícula do universo; por meio do particular (mônada), pode-se ver o universal. Existem vários níveis de mônadas, desde as mais simples como os minerais até a mônada perfeita, que é Deus. A mônada deve ser entendida em si mesma, a partir de seus princípios internos, que a fazem agir de uma forma e não de outra.

O indivíduo monadológico da psicanálise na realidade é a captação de uma contradição: sua denúncia e sua reprodução. Denúncia porque a psicanálise detém dos meios de investigar a introjeção da cultura no indivíduo, "apartando-se" momentaneamente da sociedade. E reprodução porque o indivíduo fica hipostasiado nessa separação (Crochik, 1995).

Desse modo, ao mesmo tempo em que a psicanálise pode examinar a particularização da dominação e a transformação do indivíduo em mônada, se ela se aprofunda na mônada e não 
estabelece relações com o todo, não consegue romper com o monadologismo.

No próximo capítulo, será apresentado um resumo da história da psicometria e suas aplicações. 


\section{2 \\ HISTÓRIA E CARACTERÍSTICAS DOS TESTES PSICOLÓGICOS}

\section{1 - Breve histórico da psicometria}

Quase não é possível, na raiz da psicologia e da psicometria, diferenciá-las. O modelo de ciência que fundou a psicologia fundou juntamente a psicometria.

A psicologia como ciência surgiu das mensurações das funções psíquicas do homem. Nas origens da moderna psicologia está um modelo de ciência que buscou a equiparação das ciências físicas e naturais com todas as áreas do conhecimento, a partir do século XVIII. A expansão do positivismo a partir de Comte ampliou as possibilidades do experimentalismo e da matematização do conhecimento também às 
ciências do homem. Esse crescimento foi fecundo para o surgimento de novas especializações dentro da ciência positivista, como foi o caso da psicologia.

É aceita como data da oficialização da psicologia como ramo científico do conhecimento o ano de 1879, em que foi inaugurado o laboratório de psicologia experimental de Wilhelm Wundt (18321920) ${ }^{1}$, em Leipzig, na Alemanha.

Mas, antes de Wundt, Johann Friedrich Herbart (1776-1841) fizera tentativas de formular leis sobre o psiquismo nos moldes das leis físicas. Tais enunciados concerniam à relação entre fenômenos físicos e os psíquicos (sensações) que deles advinham (Mueller, 1978).

Outros dois importantes nomes na história da psicologia, anteriores a sua fundação oficial, são os do fisiologista e anatomista E. H. Weber (1795-1878) e do filósofo Gustav Fechner (1801-1887). Weber passou de pesquisas na área da fisiologia para a psicofísica a partir de seus estudos na área sensorial. Chegou à enunciação de uma lei matemática da excitação (estímulo) e sensação, que Fechner posteriormente aperfeiçoou matematicamente, a partir do logaritmo da excitação e sensação, que ficou conhecida como lei de Weber-Fechner (Mueller, 1978).

Esses estudos marcam os primeiros usos de medidas físicas em fenômenos psicológicos.

Portanto, Wundt não foi o primeiro a realizar experimentações de ordem psicológica nos indivíduos. No entanto, seu laboratório foi o

\footnotetext{
${ }^{1}$ As datas de nascimento e morte dos pesquisadores apontados neste subcapítulo foram extraídas de Mueller (1978), p.270-2; 314; 318 passim.
} 
primeiro exclusivamente voltado para a psicologia, inclusive fornecendo formação e treinamento para os interessados na metodologia da recém-criada ciência, sendo procurado por pessoas de todas as partes do mundo (Anastasi, 1974).

Como seus antecessores, a preocupação de Wundt era mensurar os sentidos humanos, aplicando o modelo físico e natural que crescia na época. Assim também o fez o inglês Francis Galton (1822-1911). Galton porém, discípulo e primo, segundo Mueller (1978), de Charles Darwin, tentou aplicar na psicologia os temas do evolucionismo, como seleção natural, aptidão, adaptação ao meio e hereditariedade. Preocupado com isso, iniciou investigações que pretendiam diferenciar os indivíduos (aptos dos inaptos, por exemplo), começando a delinear outra ramificação da psicologia, a psicologia diferencial. As inúmeras provas elaboradas para este fim foram os rudimentos dos testes psicológicos.

Para se ter uma noção do vulto que teve a idéia de medir diferenças individuais, basta salientar que elas eram ignoradas nos trabalhos dos primeiros psicólogos, sendo consideradas enganos eventuais do processo ou mesmo inexatidão das medidas (Anastasi, 1974). Se, no resultado de um experimento, ocorresse muita variação individual, menos exato ele era considerado.

Galton destacou-se também pelas investigações estatísticas, que se mostraram necessárias para os estudos que realizava, principalmente as escalas de correlação. Um de seus eminentes seguidores foi Karl Pearson, responsável pela correlação que leva seu nome (Anastasi, 1974). 
O título psicologia diferencial foi apresentado pelo psicólogo alemão Wilhelm Stern em 1900 (Mueller,1978), época que assistiu a uma explosão de pesquisas que se utilizavam de técnicas estatísticas e psicométricas com a finalidade de diferenciar os indivíduos.

A expressão mental test apareceria na psicometria, pela primeira vez, por meio de James Cattell na publicação do artigo Mental tests and measurements, de 1890, e referia-se a provas psicológicas que visavam mensurar diferenças individuais. Cattell, embora americano, doutorara-se em Leipzig, orientado por Wundt, e fora também influenciado por Galton (Anastasi, 1974).

Os testes psicológicos do final do século XIX já pretendiam a discriminação individual, mas destacam-se como testes essencialmente sensoriais, que visavam "medidas de força muscular, rapidez de movimento, sensibilidade à dor, acuidade visual e auditiva, discriminação de peso, tempo de reação, memória" etc. (Anastasi, 1974, p.17).

Segundo Anastasi (1974), a possibilidade de aferir funções psicológicas mais complexas com a mesma precisão e objetividade das funções simples ainda causava dúvida em muitos pesquisadores dessa época. Isso, contudo, não refreou o desenvolvimento dos testes de funções complexas e a crítica de alguns cientistas aos testes sensoriais.

Um desses cientistas foi o francês Alfred Binet (1857-1911), exaluno de Charcot e que, em 1894, foi diretor do primeiro laboratório de psicologia fisiológica da Sorbonne (Mueller, 1978). 
Binet já expressava interesse em processos mentais superiores e suas pesquisas psicométricas incluíam uma "introspecção controlada" (Mueller, 1978, p.315), i.e., questionários, conversas, inquéritos etc.

Binet e Henri, já em 1895, questionavam os testes de então quanto ao sensorialismo exacerbado e ao fato de se prenderem a funções psicológicas simples, no artigo La psychologie individuelle (Anastasi, 1974).

Esse artigo foi, segundo Anastasi (1974), uma ponta de lança para uma nova fase na psicometria. Em 1904, Binet e Simon ${ }^{2}$ integraram uma comissão do Ministério da Instrução francês que estudaria "o problema das crianças anormais" (Mueller, 1978, p.315) nas escolas da rede oficial. Em resposta à demanda do governo, esses estudiosos criaram a famosa escala de inteligência de Binet-Simon, a primeira escala psicométrica de inteligência da história. Inaugurou-se, com isso, o conceito de idade mental, "um nível comparativo fundado num critério de normalidade obtido pelo êxito de 50 a $75 \%$ dos sujeitos de certa idade, antes do que uma medida propriamente dita." (Mueller, 1978).

Quanto à autoria do conceito de Q.I., quociente de inteligência, um aperfeiçoamento da idade mental, as informações encontradas diferem entre si. Mueller (1978) e Lindermann e Matarazzo ${ }^{3}$ (apud Cunha et al., 1993) apontam Wilhelm Stern. Anastasi (1974), por outro lado, relata que o Q.I. surgiria, pela primeira vez, na publicação

\footnotetext{
2 Simon, segundo Larrabure (1987), era "pedagogo" (p.27) e, de acordo com Mueller (1978), "médico do Asilo de Rouen." (p. 315).

3 Lindermann, J. e Matarazzo, J.D. Assessment of adult intelligence. In Goldestein, G. e Hersen, M. Handbook of psychological assessment. New York, Pergamon, 1990.
} 
de uma das revisões da escala de Binet-Simon, realizada sob a coordenação de Lewis Terman na Universidade de Stanford, nos Estados Unidos, no final da década de 10, escala que ficou conhecida como Stanford-Binet. Esta escala, por sinal, sofreu outras revisões posteriores, como a Terman-Merrill (Maud Merrill foi colaboradora da revisão que levou este nome).

Outro pesquisador importante dessa fase foi o inglês Charles Spearman (1863-1945), com contribuições também na estatística, havendo uma importante fórmula de correlação usada na psicologia que leva seu nome.

A psicologia desenvolveu-se para além das investigações sensoriais, mas o modelo físico-natural foi mantido.

Se traçarmos uma linha contínua do desenvolvimento dos testes, desde Wundt até Terman, notaremos que eles se sofisticam. Passam dos testes de funções simples, como as sensações, para as mais complexas, como o raciocínio abstrato. Seria decorrência da sofisticação do objeto ou de mudanças nas condições concretas de existência?

Algumas informações podem nos ajudar a pensar. Hugo Münstenberg, pesquisador alemão, doutor em psicologia por Leipzig com Wundt, estudava a fadiga humana com o auxílio dos experimentos sensoriais. Münstenberg destaca-se por seu esforço em aplicar a moderna psicologia às demandas da "vida real", como ele menciona repetidas vezes em seu livro Psychology and industrial efficiency, de 1913. 
Muito preocupados com a escola, os cientistas esqueceram-se da indústria e do comércio, diz Münstenberg (1913), que passa a dedicar-se a colocar a nova ciência a serviço destas duas áreas. Um de seus propósitos práticos é o auxílio à seleção do trabalhador mais adequado para cada função.

Sua concepção de adequação estava subsidiada em duas vertentes de análise do trabalhador: a da vocação do candidato (vocation) e seu "encaixe" ou adequabilidade ao trabalho (fitness).

Desse modo, conforme ele próprio ressalva, Münstenberg (1913) vai contra um procedimento, por assim dizer, comum na época, que era o de contratar trabalhadores baseados apenas na vontade pessoal e na vocação do candidato, na esperança de que “... desejos e interesses naturais irão empurrar todo mundo para o lugar que suas disposições, talentos e dons psicofísicos prepará-los."4 (p.29). Para ilustrar a importância da ciência na seleção, o autor cita o exemplo de um jovem que pode querer apaixonadamente ser marinheiro mas é totalmente "inadequado" (unfit) porque não possui habilidade discriminatória de verde e vermelho.

Note-se que Münstenberg (1913) faz uso da ciência psicológica experimental para examinar a "adequabilidade" (fitness) do candidato em quesitos sensoriais. Os experimentos de tempo de reação, acuidade etc. mostraram-se enormemente úteis nas demandas apresentadas pela indústria e comércio, especialmente porque ao conseguirem discriminar qual trabalhador era mais "adequado",

\footnotetext{
4 “... the natural wishes and interests will push every one to the place for which his dispositions, talents, and psychophysical gifts prepare him."
} 
aumentavam a segurança das pessoas que usufruíam daquele trabalho, os clientes. Dentre os experimentos realizados estão aqueles junto ao serviço de estrada de ferro elétrica e do serviço telefônico (Münstenberg, 1913). A indústria destaca-se, por meio de Müstenberg e outros, como um importante campo no desenvolvimento de testes desde o começo. Ressalte-se que os testes de habilidades complexas também eram muito utilizados na indústria, em seleções, na verificação dos resultados de um treinamento, entre outros, como os testes de aptidão.

Outro momento do desenvolvimento que gostaríamos de destacar é concomitante com o advento da Primeira Guerra, em especial a entrada dos Estados Unidos no combate, em 1917. Referindo-se ao impulso que o movimento psicométrico teve nos Estados Unidos após a Primeira Guerra, Mueller (1978) afirma que “a voga dos testes psicológicos está estreitamente ligada a certas condições sociais. É imensa nos Estados Unidos, onde se precisou recrutar, rapidamente, em 1917, os quadros do exército." (p.320).

A importância da guerra para o desenvolvimento dos testes foi tão grande quanto para outras criações científicas que são impulsionadas pela necessidade de vencê-la, como remédios, armamentos, meios de transporte, entre outros.

Note-se que, nesse sentido, de início os testes foram concebidos para aplicação individual. Todavia, "o teste coletivo, tal como aconteceu com a escala de Binet, foi criado para satisfazer a uma necessidade prática urgente [itálicos nossos]." (Anastasi, 1972, p.14). Quando da entrada dos Estados Unidos na Primeira Guerra, a American 
Psychological Association, no intuito de ajudar o chamado "esforço de guerra" (p.14), designou uma comissão que, sob a direção de Robert Yerkes, tinha por objetivo pensar formas de a psicologia auxiliar os Estados Unidos na guerra (Anastasi, 1972).

A comissão então observou que o exército precisava selecionar mais de um milhão de recrutas, o melhor e o mais rapidamente que conseguisse. Foi no auxílio a essa seleção que surgiram os primeiros testes coletivos da história, que eram testes de nível mental, o Army Alpha e o Army Beta. O Alpha servia à aplicação comum de rotina e o Beta era não-verbal, destinando-se a analfabetos e estrangeiros.

Assim sendo, pode-se perceber que o fato de os testes terem se desenvolvido a partir da avaliação de funções simples para as complexas e da aplicação individual para a coletiva serviu a uma série de necessidades que surgiram nos diversos campos sociais.

\subsection{1 - A psicologia da dimensão físico-natural}

Uma representante da matematização do conhecimento psicológico é a psicometria, a ciência da medição psicológica. Ela foi uma resposta especializada a uma demanda de mensuração de atributos psicológicos que já começava a se circunscrever quando do surgimento oficial da psicologia, em 1879.

$\mathrm{Na}$ história da psicometria inscrevem-se suas raízes na psicofísica, que, por sua vez, surgiu influenciada pelos estudos experimentais de fisiologia. A aproximação do modelo das ciências físicas e naturais às ciências do homem não foi uma prerrogativa 
apenas da psicologia, mas um movimento intenso e generalizado na história da ciência moderna, iniciado há aproximadamente dois séculos com a filosofia positiva, que "tendia a igualar o estudo da sociedade ao estudo da natureza, de modo que a ciência natural, particularmente a biologia, se tornava o arquétipo da teoria social." (Marcuse, 1988, p.312).

Dada sua própria característica de voltar-se ao mundo concreto buscando métodos que, sistematizados, constituiriam um instrumento cientificamente válido, a psicometria encerrava em si os ideais matemáticos que ajudariam a fazer da psicologia uma ciência tão válida como as outras, biológicas e exatas. A psicometria, portanto, impulsionou o desenvolvimento da psicologia como ciência moderna, ao mesmo tempo em que deveu seu progresso a ela.

Na citação de Decroly e Buyse ${ }^{5}$ (apud Ancona-Lopez, 1987), fica clara a preocupação em se fazer, por meio dos testes psicológicos, uma ciência irmã das ciências físicas, assim como a preocupação com a eficiência, característica do desenvolvimento técnico:

“... o método dos testes não é mais do que estender até a educação processos empregados e reconhecidos como práticos, nos outros ramos da atividade humana; é o mesmo que examinar uma rocha antes de sua exploração, um metal, a fim de Ihe determinar a resistência, um grão, a fim de lhe verificar o poder de germinação ..." (p.41).

\footnotetext{
${ }^{5}$ Decroly, D. e Buyse, R. Prática dos testes mentaes. Rio de Janeiro, F. Brigviet \& Cia. Editores, 1931.
} 
De acordo com Marcuse (1988), “o ‘dogma geral da invariabilidade das leis físicas' era chamado por Comte de 'espírito autêntico do positivismo'." (p.312).

Charles Spearman, como muitos cientistas importantes para a história da psicometria, colaborou com estudos para solidificar esta psicologia. ${ }^{6}$

O método fatorial de Spearman parte da hipótese de que, se há alguma correlação entre duas habilidades humanas quaisquer, elas igualmente terão correlação com um

\begin{abstract}
“fator comum a ambas (que determina a correlação entre essas habilidades) e um fator específico de cada uma (que determina a diferenciação entre essas habilidades). Os fatores se isolam, pois, mediante um processo de dedução lógica, baseado no exame estatístico das correlações entre as habilidades." ${ }^{7}$ (Bernestein in Spearman, 1955, p.12).
\end{abstract}

A teoria bifatorial leva este nome exatamente devido ao fato de sua base de sustentação estar na busca de correlação entre dois fatores mentais, S (específico) e G (geral), os quais tenta-se demonstrar pela pesquisa empírica estatística. Por meio dela, Spearman (1955) buscou um tratamento ao objeto que fosse tão

\footnotetext{
${ }^{6}$ É interessante, nesse sentido, mencionar a sua teoria matemática da inteligência, sintetizada na equação tetraica, uma equação de correlações de cálculo das diferentes aptidões: "rap X rbq - raq X rbq $=0$ " (Spearman, 1955, p.81), em que $r$ é coeficiente de correlação e $a, b, p$, q são as variáveis de inteligência ligadas ao fator $g$ a serem estudadas (num teste de inteligência, por exemplo, poderiam ser as diferentes provas).

7 "factor común a ambas (que determina la correlación entre esas habilidades) y un factor específico de cada una (que determina la diferenciación entre esas habilidades). Los factores se aislan, pues, mediante un proceso de deducción lógica, en base al examen estadístico de las correlaciones entre las habilidades."
} 
seguro quanto a matemática pudesse oferecer. Vale ressaltar que no mesmo intuito, seu contemporâneo, o psicólogo americano Thurstone (1887-1955), postulou a teoria de fatores múltiplos de inteligência, que na época era uma das grandes adversárias da teoria do fator G (Spearman, 1955).

A teoria bifatorial de inteligência elaborada por Spearman precipitou a criação de testes de fator G, como o Raven, ainda hoje disponível no mercado brasileiro e em uso por alguns psicólogos. A teoria de Thurstone culminou nas também muito utilizadas baterias de fatores múltiplos. Porém, como o objetivo é evidenciar uma idéia que era generalizada na psicologia de então e não fazer uma extensa revisão das teorias de inteligência, vamos tecer alguns comentários apenas sobre Spearman.

Spearman (1955) é muito claro e coerente com o pensamento positivista a respeito da opção metodológica de investigar a manifestação do objeto e não sua natureza interna. Não obstante, rejeita a idéia de se voltar ao mundo concreto sem se saber o que se está buscando. Spearman (1955) critica Terman ${ }^{8}$, que justificaria o desenvolvimento de instrumentos de medida da inteligência sem que necessariamente se tenha delimitado precisamente o que seja inteligência, fazendo um paralelo entre a inteligência e a eletricidade. A eletricidade, de acordo com Terman, foi um fenômeno investigado e medido com sucesso apesar de haver sido conceituado erroneamente quanto a sua verdadeira natureza. Por isso, Terman acreditaria que a

\footnotetext{
${ }^{8}$ Terman, L. M., The measurement of intelligence. S.I., S. ed.,1916.
} 
falta de definições precisas quanto à inteligência não seria um obstáculo para sua mensuração: “É completamente irracional exigir de uma pessoa que vá medir a inteligência que primeiro dê uma acabada definição da mesma."9 (Terman apud Spearman, 1955, p.38).

Tal não é, contudo, a opinião de Spearman (1955) num primeiro momento, que considera perigosa a confusão entre a interioridade e a exterioridade do fenômeno. Falando da corrente elétrica, ele ironiza o trabalho do físico que despreza o conhecimento das manifestações da eletricidade: "Triste apuro o do físico que tivera de medir uma corrente elétrica sem haver estabelecido antes qual dos vários galvanômetros que tem diante de si, se acha realmente em circuito com ela!"10 (p.38). Usando este exemplo da física como um paralelo para a psicologia, Spearman (1955) assevera a necessidade de uma forte sustentação teórica para investigar o que é externo:

\footnotetext{
“... talvez possamos passar sem conhecer a 'essência pura' da inteligência; mas certamente não poderemos medi-la se não decidirmos que operações mentais entram sob seu domínio. Para dizêlo com uma aproximada expressão popular: se não o que, devemos necessariamente saber, ao menos, qual é."11 (p.38).
}

\footnotetext{
9 "Es completamente irrazonable exigirle a una persona que va a medir la inteligência que primero dé una acabada definición de la misma."

10 "!Triste aprieto el del físico que tuviera que medir una corriente eléctrica sin haber estabelecido antes cuál de los varios galvanómetros que tiene delante, se halla realmente en circuito com ella!"

11 “... quizá podamos pasarnos sin conocer la 'esencia pura' de la inteligencia; pero ciertamente que no podremos medirla si no hemos decidido que operaciones mentales entran bajo su dominio. Para decirlo con una aproximada expresión popular: si no qué, debemos necessariamente saber, al menos, cuál es."
} 
Numa nota de rodapé em seu livro, entretanto, há uma indicação de que Spearman (1955) teria mudado de idéia frente a essas questões no American J ournal of Psychology, em 1904.

Apesar dessa revogação, o fato é que o enfraquecimento do conceito e sua substituição total ou parcial pelas verdades empiricamente estabelecidas foram apontados, num certo momento, por Spearman (1955).

A idéia essencial da psicometria é que não se mensura "alguém"; mensura-se seu comportamento ou atitude diante de uma situação ou determinado estímulo. Um exemplo são os fatores $\mathrm{G}$ e S de Spearman, que não devem ser tomados como "entidades reais"12 (Bernstein in Spearman, 1955, p.12), mas como abstrações conseguidas graças ao método de análise fatorial.

Passemos agora ao detalhamento do emprego de testes na educação.

\subsection{2 - O emprego de testes na escola ${ }^{13}$}

Como se viu, a primeira escala de inteligência construída na história, por Binet, tinha por fim mensurar a capacidade de alunos desajustados da rede pública francesa.

A preocupação com a mensuração de educandos é o marco zero da história das escalas mentais, num casamento da psicologia com a

\footnotetext{
12 "Entidades reales."

${ }^{13}$ Como o foco de nosso trabalho é a escola, centraremo-nos sobre suas relações com os testes psicológicos com mais detalhes do que sobre a indústria, a clínica e a guerra.
} 
pedagogia que, embora tenha modificado seu discurso ao longo do tempo, continua forte até os dias de hoje.

R. Thorndike e Hagen (1969) conseguem fazer uma boa síntese das vertentes que originaram as motivações que expandiram e popularizaram o uso de testes com vistas à educação. Estas seriam três:

“(1) a psicologia fisiológica e experimental que teve seu maior crescimento na Alemanha no século desenvolve, (2) a teoria darwiniana, e (3) a preocupação clínica com os indivíduos malajustados e subdesenvolvidos." 14 (p.3)

Como explicitam esses autores, a teoria darwiniana lançou questões acerca das variações entre os membros de uma espécie, o que delimita a preocupação com as diferenças individuais, e delas o foco foi se centrando no "indivíduo que não estava funcionando com sucesso." ${ }^{15}$ (p.4).

Segundo R. Thorndike e Hagen (1969), preocupações de cunho humanitário para com os doentes mentais e desajustados aumentaram o fluxo de pesquisas a respeito, com vistas a diminuir seu sofrimento. A partir disso, os psicólogos teriam percebido a necessidade de ter uma forma uniforme de expressar "o grau do defeito deles, particularmente na esfera mental”16 (p.4-5), o que teria estimulado o desenvolvimento de testes psicológicos.

\footnotetext{
14 “(1) the physiological and experimental psychology that had its main growth in Germany in the nineteeth century, (2) the Darwinian biology, and (3) the clinical concern for the maladjusted and underdeveloped individual."

15 "Individual who was not functioning successfully."

16 "The degree of their defect, particularly in the mental sphere."
} 
A adoção de testes psicológicos para atender problemas surgidos no âmbito escolar foi um dos principais elos que, a partir da virada do século, uniu a psicologia e a educação e, nele, a preocupação em medir a inteligência.

É preciso entender um pouco do espírito da época em que os testes psicológicos aliaram-se à educação.

Foi um período de grande estimulação tanto na pedagogia quanto na psicometria. De acordo com Patto (1993), desde a última década do século XIX até os anos 30 do século seguinte, observa-se um grande crescimento do sistema de ensino na Europa e nos Estados Unidos. Surge a Escola Nova, um movimento educacional que tinha como uma de suas bandeiras a democratização do acesso ao ensino como forma de corrigir a injustiça social. A idéia é a de não cometer injustiça com os indivíduos: não importa sua origem social, os "mais aptos" têm de ter as melhores oportunidades. Paralelamente, cresceram também as pesquisas sobre instrumentos de mensuração que, acreditava-se, seriam capazes de fazer essa diferenciação para efetivamente "beneficiar os melhores". Como mostra a autora:

\footnotetext{
“A estreita relação entre a psicologia e a sociologia científicas, de um lado, e a pedagogia científica (o movimento da Escola Nova), de outro, é uma prova concreta desta comunidade de esforços que visam a transformação de uma sociedade de classes injusta numa sociedade de classes justa." (p.42).
}

O ideário burguês de liberdade e igualdade estava ainda, segundo Patto (1993), muito forte na sociedade daquele tempo. 
Especialmente porque a Revolução Industrial e suas decorrências ampliaram de fato a mobilidade social e a ciência via-se finalmente livre da religião.

Dentro dessa perspectiva, a escola é vista como uma das instituições pelas quais a liberdade e a igualdade conseguiriam realizar-se. Porém, a essência da divisão de classes foi mostrando sua face, bem como a dificuldade de alcançar a liberdade e a igualdade numa estrutura injusta. O aumento da demanda por escola e a efetiva ampliação do sistema educacional, passando a atender maior número de pessoas, geraram, conforme Patto (1993), dois tipos de problema: as diferenças no rendimento dos alunos e a diferença de acesso dos alunos aos níveis mais elevados da escolarização. Avaliar as aptidões individuais dos escolares foi um dos procedimentos psicológicos mais usuais ante tais fenômenos, sendo, segundo essa autora, “o grande desafio que os psicólogos se colocavam na virada do século" (p.41), mas sem que a crítica à estrutura social tivesse estado tão presente em toda essa movimentação.

Edouard Claparède foi uma das grandes referências para psicólogos e pedagogos da época, autor de Comment diagnostiquer les aptitudes chez les écoliers, de 1924. Claparède defendia o aprimoramento da educação, com vistas às diferenças individuais dos educandos. Dentre suas propostas estava a da educação sob medida, em 1920 e a orientação profissional, em 1922 (Patto, 1993). Seu lema era "a colocação do homem certo no lugar certo" (p.43), o que deveria acontecer o mais cedo possível, e para isso era preciso detectar as aptidões e qualidades dos indivíduos o mais precocemente. Os testes 
eram instrumentos que contavam com a objetividade e a precisão necessárias para tal tarefa. Patto (1993) relata que houve, “nos meios universitários de países capitalistas europeus e norte-americanos, uma verdadeira cruzada em busca de instrumentos de medida das diferenças individuais." (p.43).

No contexto escolar, a avaliação dos "anormais"17, que inicialmente era médica, passa a basear-se quase que integralmente na avaliação do nível intelectual, em especial do Q.I., nas três primeiras décadas do século XX (Patto, 1993).

Nos anos 30, entraria em cena mais uma vertente de análise dos problemas escolares: a influência do meio ambiente e da relação familiar no desenvolvimento infantil, em especial nos primeiros anos de vida (Patto, 1993). Além disso, a esfera afetiva e emocional do educando passa a ser pensada no entendimento de seu comportamento. A criança desajustada, antes chamada de anormal, agora é a "criança-problema" (Patto, 1993).

A dimensão emocional do professor também passa a ser incluída, tendo em vista a saúde mental dos alunos, e os psicólogos ganham mais uma atribuição, a de orientá-los. Clínicas psicológicas são criadas dentro e fora da escola para tratamento das criançasproblema e orientação de pais e professores, além da detecção, o mais

17 Segundo nomenclatura da época, de cunho eminentemente biologizante da concepção dos desajustes sociais e influenciado pela teoria darwinista, os anormais infantis foram definidos, em 1914, nos anais do Congresso de Assistência em Montpellier, como "aqueles que, sob a influência de taras mórbidas hereditárias ou adquiridas, apresentam defeitos constitucionais de ordem intelectual, caracterial ou moral, associados no mais das vezes a defeitos corporais e capazes de diminuir o poder de adaptação ao meio no qual eles devem viver regularmente." (Patto, 1993, p.41). 
cedo possível, dos perfis dos educandos. Dentro da escola, surgem as classes fracas. A rotina de submeter os educandos aos diagnósticos feitos por testes continua forte.

Cabe agora analisar como foi o estabelecimento e crescimento da psicometria especificamente no Brasil, tendo em vista a educação.

\subsection{3 - A expansão dos testes no Brasil, no imbricamento da psicologia com a educação}

Na época da proclamação da República, que ocorreu em 1889, a economia brasileira era ainda basicamente rural. Cerca de $3 \%$ da população freqüentava a escola (Patto, 1993), o país tinha acabado de decretar a escravatura ilegal, o voto era censitário e a aristocracia rural de Minas e São Paulo revezavam-se no poder na chamada política do café-com-leite. O ensino era essencialmente confessional, organizado no âmbito da sociedade civil, e não tarefa do Estado (Freitag, 1986). Na época em que surgiram os primeiros testes mentais na Europa e nos Estados Unidos, o Brasil estava, pois, neste contexto sociopolítico e econômico: um país rural e aristocrático, em que a escola era a realidade de muito poucos.

Esse fato traz um apontamento importante: a ciência moderna, em especial a psicologia e por extensão a psicometria é, como vimos, uma decorrência de uma visão de mundo que condizia com transformações reais que estavam acontecendo no corpo social que ainda eram uma realidade distante no Brasil de então. O uso de testes, que foi grandemente estimulado ao verificar-se sua utilidade quando 
aplicado à indústria, à escola e à clínica, no Brasil simplesmente não fazia sentido, visto que, segundo Romanelli (1999), o sistema de ensino não se popularizou até os anos 30 e a Revolução Industrial chegou aqui com quase um século de atraso.

O quadro começou a mudar a partir da Revolução de 30, que,

"resultado de uma crise que vinha de longe destruindo o monopólio do
poder pelas velhas oligarquias, favorecendo a criação de algumas
condições básicas para a implantação definitiva do capitalismo
industrial no Brasil, acabou (...) criando também condições para que se
modificassem o horizonte cultural e o nível de aspirações de parte da
população brasileira, sobretudo nas áreas atingidas pela
industrialização." (Romanelli, 1999, p.60).

Os anos 20 foram a ante-sala de transformações importantes na educação brasileira (Patto, 1993). Havia uma grande movimentação intelectual de renovação na área educacional, um grande entusiasmo por parte dos educadores, influenciados pelas idéias americanas e européias, "às vezes vistas de maneira impropriamente reunidas sob o nome de "Movimento de Escolas Novas." (Romanelli, 1999, p.129). Dois novos prismas surgem na educação, o da sociologia e o da psicologia (Romanelli, 1999).

Uma série de reformas educacionais locais prenunciava grandes mudanças, como as de Sampaio Dória em 1920 e Lourenço Filho em 1922-23 (Romanelli, 1999). Nem todos estavam satisfeitos com a política do café-com-leite, o Brasil começava a industrializar-se, 
centros urbanos cresciam, havia um grande fluxo imigratório e isso tudo mudou parte do Brasil.

Segundo Patto (1993), durante os anos 10, 20 e 30, a aproximação entre a psicologia e a pedagogia no Brasil visava basicamente experimentos psicofísicos e não mensurações de desvios e classificações. Estas viriam posteriormente, com a ampliação do sistema educacional no país e, acrescentamos, talvez também devido ao crescimento da indústria. Além disso - diferentemente do que acontecia na Europa e nos Estados Unidos nessa época, em que as concepções organicistas de homem, por vezes tingidas pelo racismo científico, foram perdendo força, dividindo espaço com as idéias ambientalistas, influenciadas pela psicanálise - no Brasil ainda se estava no organicismo (Patto,1993). Conforme observa essa autora, elas foram o berço teórico de toda uma geração de profissionais que atuaria depois nas questões escolares, impingindo nela sua marca, inclusive na apropriação e reprodução da psicometria na realidade brasileira.

De forma mais ou menos acentuada, os reprodutores dessas idéias no país salientaram sua própria filiação teórica orgânica, biológica e por vezes racista, em suas acepções, que, paradoxalmente, conviviam com idéias liberais, formando um bloco teórico - que sustentou depois a prática que se fez - e caracterizou a apropriação brasileira dessas idéias estrangeiras (Patto, 1993).

Com a expansão da escola, nas décadas seguintes o Brasil enfrenta o fracasso escolar e, segundo Patto (1993), duas perspectivas de análise abrem-se no campo educacional. A primeira congrega 
educadores e filósofos educacionais que se propõem pensar a educação em seus aspectos estruturais e funcionais. A outra centra-se na abordagem biológica, psicológica e social dos educandos. A partir dos anos 60, a autora relata um enfraquecimento da primeira tendência, em favor da segunda.

Resumindo, os testes psicológicos no Brasil, tal qual em seus países de origem, quando usados no intercâmbio entre a psicologia e a educação, foram requisitados no momento em que a escola se deparava com um certo contingente de sua clientela que não se ajustava a ela. Mas, além disso, expandiu-se numa época em que se buscava "fazer justiça aos melhores" e acreditava-se que a ciência e seu método seriam o caminho mais apropriado para isso.

O movimento psicométrico acompanhou, também, uma tendência histórica de centrar no indivíduo as explicações sobre seu desajustamento social. Além disso, dadas as características sociopolíticas e econômicas nacionais, os ideários racistas e organicistas terminaram predominando ou de certa forma tingindo a apropriação das idéias e práticas estrangeiras nessa área.

Franco (1990) traz elementos a mais à questão, ao discutir a influência da psicologia positivista na escola, identificando três matrizes epistemológicas de avaliação escolar. A primeira, denominada objetivista, seria oriunda do modelo científico positivista. É interessante observar que, segundo Franco (1990), é à psicometria e à psicologia científica do século XIX que as avaliações de matriz objetivista devem seu impulso na escola. A partir da busca da objetividade no conhecimento, as avaliações objetivas dos alunos 
passariam a ser valorizadas e novas formas teriam sido criadas, como as questões-teste, a exemplo dos testes psicológicos.

Na década de 70, a crítica a esse modelo levaria a uma matriz oposta, a subjetivista (Franco, 1990). Nesta, a objetividade da avaliação não seria tão relevante quanto a demarcação da subjetividade como elemento presente e válido para o conhecimento e avaliação: “começaram a surgir sérios questionamentos em relação à aplicação de testes padronizados [de avaliações escolares] e à absorção acrítica de seus resultados." (p.65).

Em seguida, os preceitos dos testes.

\section{2 - Testes psicológicos}

\subsection{1 - Características do teste: padronização, normas, precisão e validade}

Segundo Anastasi (1972), “teste psicológico é, fundamentalmente, uma medida objetiva e padronizada de uma amostra de comportamento." (p.26).

Van Kolck ${ }^{18}$ (apud Larrabure, 1987) o apresenta como "um procedimento que busca medir o fenômeno psicológico e, portanto, procura atender às exigências do método experimental." (p.29).

\footnotetext{
18 Van Kolck, O.L. Técnicas de exame psicológico e suas aplicações no Brasil. Petrópolis, Vozes, 1974.
} 
Korchin ${ }^{19}$ (apud Larrabure, 1987) o define sendo "uma situação estandardizada na qual o comportamento de uma pessoa é mostrado, observado e descrito." (p.29).

Destaca-se, nestas citações, a circunscrição do teste psicológico a campos como padronização, estandardização, mensuração objetiva.

Anastasi (1972) afirma que a “aplicação, a avaliação e a interpretação de resultados são objetivos, na medida em que independem do julgamento subjetivo de determinado examinador." (p.30)

A objetividade preconizada do teste psicológico é positivista e, assim sendo, é fundamental para definir seu valor e utilidade como instrumento científico. No positivismo, a verdade estaria no dado objetivo e, para alcançá-la, o método pressupõe o afastamento entre sujeito e objeto.

Como já se viu, essa separação permitiria que o objeto permanecesse "verdadeiro", livre da contaminação subjetiva, e que a verdade fosse então "lida" corretamente pelo sujeito do conhecimento. Dessa forma, o dado objetivo é considerado neutro porque livre de intencionalidade na manipulação da natureza: “objetivo em si mesmo".

A conceituação positivista de objetividade, entretanto, difere frontalmente da concepção dialética, que não vê subjetividade e objetividade como "instâncias", como fazem não apenas o positivismo mas muitas de suas críticas, de forma espelhada.

${ }^{19}$ Korchin, S.J. Modern clinical psychology. New York, Basic Book, 1976. 
Na dialética, objetividade e subjetividade não estão cindidas, mas profundamente implicadas. A verdade não estaria na distância do sujeito em relação ao objeto, mas na tensão entre ambos. O sujeito deve ser não apenas sujeito, mas também objeto e assim, quanto mais se debruçar sobre o subjetivo, maior objetividade alcançará porque se defrontará com a intencionalidade do pensamento no próprio pensamento. Para que a pesquisa seja dialeticamente objetiva, mais subjetiva deverá ser. Conforme Habermas (1980),

\footnotetext{
“a interpretação sociológica identificadora e crítica se articula no espírito objetivo onde se dá a existência social. A formalização não se constitui para a dialética num recurso para a eliminação dogmática das situações existenciais, ao contrário, é no processo das mesmas que encontra o significado subjetivo materializado através das instituições existentes, e por assim dizer, mantém-no em suspenso." (p.282-283).
}

Na busca do dado positivo, o teste será guiado pelos critérios "palpáveis" do mundo externo ao sujeito, do mundo que se acredita, seja objetivo, ao qual se teria acesso "por fora". Como afirmam R. Thorndike e Hagen (1969), “'conhecer' uma pessoa significa ser capaz de descrevê-la acurada e totalmente. ${ }^{20}$ (p.8).

Ao se tratar da objetividade científica do teste, se é remetido a seus quatro pilares empíricos de sustentação: padronização, normas, precisão e validade. São esses quatro fundamentos internos e sua determinação empírica que garantem seu valor e confiabilidade científica. 
Ser um teste padronizado significa que, quer em sua aplicação, quer em sua avaliação, em qualquer lugar em que estas ocorram, os mesmos procedimentos serão adotados por aplicadores e avaliadores. É isso que permite a comparação dos resultados do indivíduo testado com os resultados da amostra-padrão, uma vez que nas situações nas quais os testes foram aplicados os mesmos critérios foram seguidos.

Anastasi (1972), ao admitir a influência da subjetividade nas situações de teste, marca a importância da manutenção de condições padronizadas de aplicação, para controlá-la:

“... todas as aplicações de testes estão, até certo ponto, sujeitas à interação social e situacional (...) existem provas da influência da interação emocional entre examinador e sujeito, nos resultados obtidos com testes individuais de inteligência (...) Todavia, disso não se deve concluir pelo afastamento da prática de aplicar testes sob condições padronizadas. Ao contrário, o examinador deve estar ainda mais alerta, a fim de controlar as condições que podem ser mantidas uniformes, de maneira a conservar a aplicabilidade das normas. Ao mesmo tempo, todos os aspectos da situação específica de teste que não possam ser controlados, devem ser claramente reconhecidos e considerados, na interpretação das respostas ..." (Anastasi, 1972, p.79).

Anastasi ( 1972) menciona o "viés inconsciente do avaliador" ( $p$. 84), relatando a existência de técnicas que ajudam no controle de emoções que possam atrapalhar o desempenho do sujeito no teste. Isso mostra a preocupação em se manter uma certa uniformização no

20 "To 'know' a person means to be able to describe him accurately and fully." 
processo, tornando-o menos vulnerável a mudanças idiossincráticas nas aplicações dos testes, modificando o desempenho dos sujeitos nessas condições. Conforme advoga, “ignorar as fontes inevitáveis de variação não impede a sua influência." (p.79).

A padronização de condições de aplicação visa, portanto, não apenas a proteção do examinador contra o particular, mas do examinando contra vieses dos aplicadores na situação de testagem, garantido-Ihe condições de aplicação em pé de igualdade com outros testandos, e vice-versa em relação ao examinador.

Amostra-padrão, amostra de padronização ou ainda amostra normativa é uma fração representativa da população a ser pesquisada, usada pelo pesquisador para o estabelecimento das normas do teste. Uma das etapas da construção de um teste implica a obtenção de uma amostra-padrão e consegui-la é uma tarefa tão complexa que existe um ramo da estatística denominado "Amostragem" (Bussab e Morettin, 1994, p.186), que dá conta de técnicas de obtenção de amostras representativas. A representatividade é um atributo para ao qual se deve prestar a máxima atenção. Se o pesquisador vai verificar a qualidade do ensino em São Paulo, provavelmente fará diferença colher dados no ensino público e no ensino privado.

Basicamente, a amostragem conta com duas vertentes de trabalho: os "planos probabilísticos e os não-probabilísticos." (Bussab e Morettin, 1994, p.186). Nos planos probabilísticos, desenvolvem-se procedimentos para a coleta aleatória de elementos da amostra, de modo que cada um tenha definida de antemão sua probabilidade. Nos 
não-probabilísticos, encontram-se as técnicas de “amostras intencionais (...) e amostra de voluntários." (p.186).

A escolha, portanto, de uma amostra normativa não é casual nem intuitiva, mas um processo objetivo e estatisticamente controlado.

Um teste ou uma pesquisa quantitativa que pretendam mais do que ser um estudo exploratório não podem ter seus resultados levados a sério se não cumprirem este quesito básico, qual seja, formular seus resultados a partir de uma amostra realmente representativa da população em questão.

Diante de tantos cuidados e procedimentos para chegar a amostras representativas da população almejada, é de esperar que os resultados do teste ou pesquisa não possam ser extrapolados para fora da população para a qual foi destinada. Anastasi (1972) é bem clara neste aspecto:

\footnotetext{
“Uma norma, qualquer que seja a sua expressão, restringe-se à população determinada da qual foi derivada. 0 aplicador de teste nunca deve esquecer a maneira pela qual se estabelecem as normas. Estas não são, de forma alguma, absolutas, universais ou permanentes [negritos nossos]." (p.118).
}

As normas são exatamente os resultados da amostra-padrão mediante o teste, que servem de guia para a interpretação do resultado bruto ${ }^{21}$ do sujeito.

\footnotetext{
${ }^{21}$ Resultado bruto é a pontuação do sujeito no teste, sem haver sido comparado com a amostra de padronização. Por exemplo, num teste de aptidão, o resultado bruto pode ser a quantidade de itens que o indivíduo acertou.
} 
O estabelecimento de um padrão para o teste e sua normalização visam sua uniformização e universalização (ou seja, permitir sua aplicação em qualquer lugar desde que sua padronização seja seguida).

Anastasi (1972) também recomenda que o psicometrista trabalhe com a curva normal ${ }^{22}$, inclusive orientando que, caso os dados coletados não se distribuam normalmente com a escala construída, o pesquisador manipule o nível de dificuldade do teste até consegui-la. Este trabalho todo tem um bom motivo: a curva normal propicia uma leitura mais fácil do desempenho médio, vindo ao encontro da expectativa quanto à utilidade e aplicação do teste como um instrumento que aponta onde a normalidade se encontra (no meio da curva) e onde ela não se encontra (nas pontas). Vale lembrar que ela é uma curva probabilística, o que significa que seus resultados nunca são exatos, mas expressam a chance de aquele determinado evento ocorrer. A probabilidade de essa previsão estar errada também é estatisticamente calculada, e geralmente escolhe-se previamente algum valor entre 0,01 ( 1 chance de erro em 100) e 0,05 (5 em 100), o que torna as curvas probabilísticas, quando provenientes de amostras representativas, bastante seguras. Não obstante, muito embora as tabelas de padronização contemplem os desvios-padrão, ainda são probabilidades e, portanto, em muitos casos é necessária uma confirmação do resultado por outra via. No entanto, para o psicólogo que as consulta, o dado principal a ser buscado é a posição

\footnotetext{
${ }^{22}$ A curva normal ou curva do sino é aquela cuja distribuição concentra os resultados em torno da média, tendo aí sua maior amplitude, estreitando-se nas pontas.
} 
do indivíduo testado em comparação à população em geral, pois, em última instância, é essa a utilidade das tabelas e dos procedimentos estatísticos que lhe servem de base.

De acordo com Anastasi (1972), apenas por meios empíricos é possível verificar a qualidade e eficiência de um teste. E a única forma de realizar a "avaliação objetiva dos testes" (p.34) é determinando sua precisão e sua validade.

Segundo a autora, o vocábulo precisão, na psicometria, "sempre significa estabilidade ou consistência (...) é a consistência de
resultados obtidos pelo mesmo indivíduo, quando testado novamente
com o mesmo teste, ou com sua forma equivalente." (Anastasi, 1972,
p.34).

Ou seja, ela verifica se o teste, aplicado em formas diferentes aos mesmos indivíduos em diferentes oportunidades, mantém o mesmo resultado.

Vinculada à precisão está a idéia de erro de mensuração (Anastasi, 1972). O erro de mensuração indica a "amplitude de flutuação, que tende a ocorrer num único resultado do indivíduo, como conseqüência de fatores casuais e sem significação." (p.127). Ele é um indicativo da consistência dos resultados, mostrando até que ponto as diferenças encontradas são reais ou foram uma eventualidade da mensuração.

O conceito que define essas diferenças eventuais da mensuração é a variância de erro (Anastasi, 1972). A variância de erro diz respeito 
às vicissitudes que atravessam a testagem mas não têm relevância para os objetivos do teste. Ela é definida segundo os objetivos de cada teste. O que pode ser variância de erro em um pode ser o dado pesquisado em outro.

A padronização, com a conseqüente uniformização das condições de aplicação, instruções, materiais, relacionamento com o sujeito etc., visa a redução da variância de erro, tornando os resultados do teste mais precisos (Anastasi, 1972). Por este motivo, as mesmas condições a que estava submetida a amostra-padrão devem ser mantidas pelos aplicadores do teste quando este estiver liberado para uso.

Ao considerarem, na amostra-padrão, uma série de fatores que pode influenciar a realização do teste, seus idealizadores estão pensando que esses fatores também possam acontecer com os futuros sujeitos testados. Esta é a função da amostra-padrão, ser representativa inclusive para determinação da variância de erro.

Existe, portanto, uma vasta gama de procedimentos estatísticos que visa a correção de idiossincrasias, problemas detectados ou supostos de ocorrência na amostra-padrão.

Um destes, citado por Anastasi (1972), prevê a reaplicação do teste nos mesmos sujeitos, para que se verifique até que ponto ele é temporalmente estável, o que indicaria o limite do teste às influências casuais e do dia-a-dia, no sujeito e na aplicação. A autora recomenda que o intervalo de tempo seja relativamente curto, para que os resultados da precisão não sejam influenciados pelas mudanças que ocorrem nas pessoas com o tempo, principalmente nas crianças. 
A “amostragem de item" (Anastasi, 1972, p.131) é outro exemplo de técnica de determinação da precisão. Nesta, o desempenho dos sujeitos no teste está ou não dependendo de fatores peculiares aos itens selecionados. Por exemplo, numa prova de raciocínio matemático, apresenta-se aos sujeitos uma lista de 10 problemas. Posteriormente, é apresentada uma segunda lista de 10 problemas, elaborada com os mesmos propósitos. A precisão dos itens será determinada pelas alterações detectadas no desempenho das duas listas. Pequenas diferenças serão encontradas devido a diferenças individuais. Porém, se forem muito discrepantes, o teste mostra não ter muita precisão.

Em testes que dependem consideravelmente da relação entre examinador e examinando, nos quais o primeiro tem um papel fundamental para o êxito da aplicação, existe também a “precisão do examinador" (Anastasi, 1972, p.134), que mostra sua relevância na prevenção das idiossincrasias muito significativas entre as aplicações do mesmo teste.

Enfim, a precisão é um procedimento baseado na estatística que, pode-se dizer, corrige matematicamente discrepâncias causadas por fatores externos aos objetivos do teste, como tempo e espaço de aplicação e influências subjetivas do examinando, examinador e avaliador. É um processo utilizado para se verificar a consistência entre dois conjuntos de resultados, desde testes inteiros até itens separados. 
Vamos considerar agora a validade. A validação de um teste é crucial, pois ela expressa "o grau em que o teste mede, efetivamente, o que pretende medir." (Anastasi, 1972, p.35).

Anastasi (1972) a considera o momento mais importante do teste. Sem dúvida, concordamos com ela. É quando o teste vai “ser testado". Ela é a verificação matemática da "mensurabilidade" do teste, a partir de "critérios externos e independentes daquilo que o teste pretende medir." (p.35). Esses critérios servem de "espelho" ao teste e variam de teste para teste.

O importante é que o critério forneça uma medida "objetiva" do indivíduo testado com a qual se possa correlacionar seu desempenho no teste. Esta medida de correlação é chamada "coeficiente de validade." (Anastasi, 1972, p.35). Se a correlação for baixa, significa que há uma baixa correspondência entre o teste e o critério de medida e, se a correlação for alta, a correspondência é também alta.

O nível de predição do teste, como toda medida estatística, contém uma margem de erro. Esta margem, porém, será tão pequena quanto mais válido for o teste (Anastasi, 1972).

A validade é importante também na medida em que coloca limites para o alcance do teste em questão, ao determinar que ele é válido para medir determinadas características mas não outras. Isso evita - ou deveria evitar - generalizações no uso do teste, situando-o em relação àquilo que é proposto medir e à população para a qual foi validado.

São vários os modos para se determinar a validade. A American Psychology Association, cujas referências são em geral utilizadas 
também no Brasil, a qualificou em quatro espécies: do conteúdo, que examina o conteúdo do teste; da predição, indicando a eficiência de um teste ao predizer um resultado futuro; simultânea, validando um teste em relação a um critério já existente e, finalmente, validade do conceito, verificando em que medida o teste mede o conceito que se propõe medir (Anastasi, 1972).

Por exemplo, na validade de predição de um resultado futuro, os critérios externos devem possibilitar uma leitura do desempenho posterior do examinando com a qual se possa relacionar o resultado do teste. Anastasi (1972) cita os três critérios mais utilizados: “aproveitamento acadêmico geral, realização no treinamento especializado e no trabalho." (p.169). O aproveitamento acadêmico geral incluiria notas, prêmios escolares, a avaliação de professores quanto a sua capacidade intelectual e outros índices de seu aproveitamento acadêmico.

A validade do conceito é, também, especialmente importante. Ela envolve formas de saber, objetivamente, se o conceito teórico que o teste se propõe medir, como inteligência, raciocínio matemático etc., está sendo efetivamente mensurado. Essa espécie de validade pode ser obtida por meio de várias técnicas. Anastasi (1972) cita a “diferenciação de idade, correlações com outros testes, análise fatorial e influência de variáveis experimentais nos resultados dos testes." (p.178). Vários testes são validados conforme a diferenciação de idade, como o Stanford-Binet e vários testes escolares (Anastasi, 1972). 
A validade do conceito por diferenciação de idade só é válida para características que apresentam diferenças de forma visível e consistente de acordo com a idade. No entanto, para Anastasi (1972), a diferenciação de idade não definiria de forma muito precisa o campo envolvido pelo teste, pois "uma medida de peso ou altura também apresentaria aumentos regulares, de acordo com a idade, mas evidentemente não seria planejada como um teste de inteligência." (p. 178-9)

Anastasi (1972) faz um alerta também quanto às interpretações desta forma de validade:

\footnotetext{
“Um teste psicológico validado com relação a esse critério mede características de comportamento que aumentam de acordo com a idade, sob as condições existentes no tipo de ambiente no qual o teste foi padronizado. Como diferentes culturas podem estimular e favorecer o desenvolvimento de diferentes características de comportamento, não se pode supor que o critério de diferenciação de idade seja universal. Tal como todos os outros critérios, está circunscrito ao ambiente cultural específico no qual foi criado." (p.179).
}

Outra forma de validade de conceito citada como prova da medida do que o teste mede é sua correlação com testes anteriores a ele, que abrangeriam a mesma área de comportamento, de forma geral (Anastasi, 1972).

A análise fatorial é citada por Anastasi (1972) como um método importante de validação de testes, que teria como principal objetivo “simplificar a descrição do comportamento, através da redução a 
poucos fatores ou traços comuns, do número de categorias obtidas a partir de uma multiplicidade inicial de variáveis do teste." (p.180).

\subsection{2 - Classificação dos instrumentos psicológicos de medida ${ }^{23}$}

Dada a gama de variações existentes com relação aos testes, muitas espécies de classificação são possíveis. Optou-se aqui por seguir a linha de Anastasi (1972), por parecer suficientemente completa e organizada, segundo a qual os testes são geralmente classificados com base nos "aspectos do comportamento que examinam." (p.38). Embora para a autora esta classificação seja discutível devido a sua arbitrariedade e fluidez, na prática se mostraria vantajosa.

De acordo com esse critério, portanto, os testes são divididos em quatro categorias básicas: os de inteligência geral, os de aptidões múltiplas, os de aptidões específicas e os testes de personalidade.

Os testes de inteligência geral, como dito anteriormente, foram os primeiros testes psicológicos a serem criados. Seu objetivo é a mensuração do nível geral de inteligência do indivíduo, fornecendo uma medida dela.

\footnotetext{
${ }^{23}$ Os testes psicológicos são uma forma de avaliação, assim como a psicologia dispõe de outras, como a entrevista, as dinâmicas de grupo, a observação etc. Talvez, para o leitor, a crítica colocada neste trabalho proceda também para essas outras formas de avaliação psicológica. As possíveis semelhanças poderão ser eventualmente apontadas neste trabalho, porém, está para além de seu escopo a análise mais aprofundada de tais relações.
} 
Entretanto, eles foram criticados por alguns psicólogos porque abrangeriam apenas um aspecto da inteligência, geralmente verbal ou numérico (Anastasi, 1972). De acordo com a autora, a partir dessas críticas foram criadas as baterias de aptidões múltiplas, por essas abarcarem uma amplitude maior do funcionamento psicológico, não fornecendo apenas um único resultado (Anastasi, 1972).

Cabe salientar que tanto um tipo de teste como o outro seguiram uma divisão teórica quanto ao entendimento da inteligência, o primeiro essencialmente baseado no fator $G$ de Spearman e o segundo na teoria de fatores múltiplos de Thurstone. Retornar-se-á brevemente ao fator $\mathrm{G}$ no próximo subcapítulo.

Há também os testes de aptidões específicas, cujo desenvolvimento antecede ao de aptidões múltiplas e foi estimulado pela preocupação com a avaliação de aptidões que os testes de inteligência geral não abrangiam, como a musical, a mecânica, entre outras (Anastasi, 1972). Aqui encontram-se os testes de "seleção vocacional." (p.39).

Ressalte-se que, de acordo com a autora, conforme a psicometria foi se aperfeiçoando, foi se percebendo a limitação de muitos testes, como os de inteligência geral. Ter-se-ia desenvolvido maior precisão na designação das habilidades medidas pelo teste. Desse modo, os antigos testes que pretendiam avaliar a inteligência foram sendo questionados:

\footnotetext{
“...alguns testes que, na década de 1920-1930, seriam

conhecidos, provavelmente, como 'testes de inteligência', são
} 


\begin{abstract}
atualmente descritos como 'testes de aptidão escolar'. Essa mudança na terminologia foi feita por causa do reconhecimento de que muitos dos denominados testes de inteligência medem a combinação de habilidades exigida pelo trabalho acadêmico [negritos nossos]." (Anastasi, 1972, p.15).
\end{abstract}

Diante dessa aparente volatilidade do conhecimento científico, cabe uma indagação óbvia: o que se faz com os casos que sofreram as conseqüências de um diagnóstico equivocado? E, visto de outra forma, será que os mesmos equívocos não estarão sendo repetidos na atualidade?

Outra diferenciação dos testes é a dos testes de aptidão dos testes de aproveitamento (Anastasi, 1972). Segundo ela, os testes de aproveitamento seriam "planejados a fim de verificar os efeitos de um curso especificado de treinamento." (p.40).

Os testes de personalidade são aqueles programados para a mensuração de fatores de personalidade, tais como traços sociais, psicopatologias etc. Dentro desse objetivo, existem vários recursos possíveis, como os testes projetivos, os inventários e escalas (espécies de questionários padronizados), as provas situacionais (replicação padronizada de uma situação de que se quer saber o comportamento do sujeito), entre outros.

Mais comuns entre os testes de inteligência, existem também os testes individuais e os testes coletivos (Anastasi, 1972). Os testes individuais são aqueles cuja aplicação só comporta um sujeito por vez, ao passo que com os coletivos consegue-se ampliar o número de testandos ao mesmo tempo na aplicação. É interessante notar que, ao 
comparar as vantagens e desvantagens entre testes individuais e coletivos, Anastasi (1972) pondera que os primeiros forneceriam uma maior coleta de dados qualitativos do sujeito, pelo fato de haver maior contato entre ele e o aplicador, o que permitiria extrair "valiosas observações auxiliares." (p.42). Já dentre os argumentos favoráveis aos testes coletivos, ela aponta que, pelo fato de o aplicador manter maior distância do examinando, a objetividade do processo ficaria mais preservada, não obstante tenha caracterizado positivamente a proximidade favorecida pelos testes individuais.

Outra categoria de teste são os chamados "testes de papel-elápis e os de execução" (Anastasi, 1972, p.43).

No papel-e-lápis, o sujeito escreve as respostas dos itens no local apropriado e, nos de execução, o sujeito é inquirido a manipular determinados objetos e/ou executar certas tarefas. A esse respeito, é interessante relatar uma observação feita por Terman e Merrill (1966) ao discutirem a avaliação dos itens do Stanford-Binet, que não seguiria critérios puramente mecânicos: "a avaliação das provas de BINET nunca poderá ter a objetividade de certas provas de papel e lápis que se corrigem por meio de um padrão ou modelo." ${ }^{24}$ (p.67). O papel do examinador se torna mais complexo: "até um examinador acostumado com este tipo de trabalho se encontrará alguma vez com respostas que Ihe serão difíceis de avaliar em mais ou menos." 25 (p.67).

Isso porque algumas provas do Stanford-Binet são de execução complexa e o desempenho do indivíduo testado não é facilmente

\footnotetext{
24 “la valoración de las pruebas de BINET nunca podrá tener la objetividad de ciertas pruebas de papel y lápiz que se corrigen por medio de un patrón o modelo."
} 
traduzido para os termos binários da matemática (por exemplo, de acerto ou erro). Os autores da revisão do Stanford-Binet mostram o paradoxo que têm diante de si, na assunção de certa "subjetividade" na testagem. Isso retiraria o teste da esfera, por assim dizer, puramente objetiva e - exatamente por isso - traria, para esses autores, mais riqueza ao processo:

\begin{abstract}
“Apesar da natural aspiração de ver a escala de BINET completamente livre de toda subjetividade em sua avaliação, há que se reconhecer que esta limitação é o preço com que pagamos sua grande flexibilidade e riqueza, em comparação com os demais testes de rígida avaliação com padrões fixos." ${ }^{26}$ (p.67-8).
\end{abstract}

Há ainda a diferença entre os testes verbais e não-verbais. Como o título sugere, nos não-verbais, a linguagem falada ou escrita não é exigida, ao contrário dos testes verbais.

Por último, Anastasi (1972) cita a distinção entre os “testes de rapidez e os testes de capacidade." (p. 45). Nos testes de rapidez, a característica individual a ser mensurada é a rapidez para determinada(s) tarefa(s). Para tal, segundo a autora, eles são construídos com itens relativamente fáceis e o tempo geralmente não é longo o suficiente para completar todos eles.

\footnotetext{
25 “Incluso un examinador avezado en este tipo de trabajo se encontrará alguna vez com respuestas que le resultarán difíciles de valorar en más o en menos."

26 "a pesar de la natural aspiración de ver la escala de BINET completamente libre de toda subjetividad en su valoración, hay que reconocer que esta limitación es el precio con que hemos de pagar su gran flexibilidad y riqueza, en comparación com los demás tests de rígida valoración com patrones fijos."
} 
Nos testes de capacidade, ao contrário, os itens apresentam graduação do nível de dificuldade e o tempo é calculado de modo a permitir que o sujeito consiga resolver todos os itens (Anastasi, 1972).

\subsection{3 - O tríplice objetivo: precisão, rapidez e economia}

Os testes visam a economia de recursos materiais e humanos, otimizando seu uso: "a pesquisa para criação e aperfeiçoamento das técnicas de avaliação dirige-se para esse tríplice objetivo de precisão, rapidez e economia." (Anastasi, 1972, p.80).

A redução do papel do aplicador e a uniformização do processo, possibilitando a replicação em grande escala, são fundamentais para atingir as metas econômicas do teste.

O teste é um gerador de mais-valia. Em muitas empresas ou instituições, é notável a economia de mão-de-obra de profissionais de psicologia quando estes fazem uso de testes. No lugar de um certo número de psicólogos para realizar uma seleção sem testes, em que o investimento pessoal e portanto financeiro é maior, com entrevistas e dinâmicas de grupo, por exemplo, pode-se ter menos profissionais selecionando o mesmo número de candidatos. Um diagnóstico que levaria algumas sessões para se realizar sem o teste de inteligência pode acontecer em uma ou duas sessões se feito com o teste. Como diz Ancona-Lopez (1987), “os testes psicológicos são citados como sendo, ainda, os melhores instrumentos para se obter o maior número de informações sobre um indivíduo no menor tempo possível." (p.64$5)$. 
Os testes coletivos são um aprimoramento deste objetivo, incrementando a produção de mais-valia ao poder ser aplicado em larga escala. Além de aproveitar mais os recursos materiais, há também mais ganho em termos de recursos humanos, uma vez que "o papel do aplicador é reduzido, e a avaliação pode ser feita automaticamente." (Anastasi, 1972, p.42). A eliminação da subjetividade no processo como forma de incrementar a produção (Crochik, 1990) é o modus operandi dos testes coletivos, mais do que no caso dos individuais.

Em outra passagem, Anastasi (1972) volta a referir-se ao triplo objetivo de qualquer teste, que é especialmente alcançado nas testagens coletivas:

“... na seleção e aplicação dos processos de avaliação, as principais considerações referem-se à precisão, rapidez e economia. Estas duas últimas são especialmente importantes em programas de aplicação em larga escala. A eficiente operação do programa de avaliação, com um mínimo de esforço inútil, auxilia na redução do custo." (p.79).

\subsection{4 - A avaliação por testes da clientela escolar no Brasil}

Primeiramente, cabe frisar que, no Brasil, o emprego de testes psicológicos é função privativa do psicólogo, definida a partir da Lei 4.119 de 27/08/1962, Capítulo III, Parágrafo $1^{\circ}$, sendo senão a única talvez a atividade profissional que mais distinga a categoria. 
Em termos de obras nacionais de consulta para orientação quanto à aplicação de testes psicológicos em processos diagnósticos, a de Jurema Alcides da Cunha et al., Psicodiagnóstico-R figura entre as mais importantes e consultadas entre nós.

No diagnóstico de crianças, aquelas portadoras de queixa escolar não podiam estar excluídas dessa obra, já que constituem uma faixa importante da clientela que chega aos consultórios e clínicas psicológicas dos grandes centros urbanos.

Cunha et al. (1993), no entanto, não tratam diretamente do diagnóstico de uma população específica, conquanto o objetivo da obra é auxiliar o processo diagnóstico, elucidando e discutindo uma série de técnicas e procedimentos para tal. Mas, considerando a tendência histórica de diagnosticar escolares a partir de testes de inteligência, baseamo-nos neles na consulta a esse livro.

De fato, em algumas passagens os autores relacionam o teste de inteligência ao diagnóstico de crianças com problemas de aprendizagem, sem entretanto recomendar que o psicólogo o faça baseando-se apenas no teste mental.

Cunha et al. (1993), assim como outros psicólogos na área de testes no país, defendem que o diagnóstico seja feito a partir da análise de dados quantitativos e qualitativos, que o momento da testagem pode inclusive fornecer.

Dentre os testes mais utilizados no Brasil estão os do grupo Weschler de inteligência. Idealizadas por David Weschler, as escalas Weschler (WISC-R, WISC-III, WAIS, WAIS-R, WPPSI...) constituem uma família de escalas derivadas da Weschler-Bellevue Scale, de 1939, 
cujo primeiro descendente foi o WISC (Weschler Intelligence Scale for Children ${ }^{27}$ ).

Embora utilizadas no Brasil, especialmente o WISC, não obtiveram normalização nacional e, não obstante algumas já estejam em versões bem avançadas nos Estados Unidos, no Brasil estas ainda são pouco difundidas, porque não apenas não contam com a normalização brasileira, como também não foram traduzidas para o português (Cunha et al., 1993). No caso do WISC, que será abordado em mais detalhes adiante, acaba prevalecendo, entre nós, a escala original da década de 40.

A falta de normalização brasileira e atual atinge vários outros testes e técnicas, como o Bender, o Rorschach, o HTP etc.

A exceção parece ser o Raven, cuja revisão de 1956 da Escala Especial foi editada em 1988 com normalização brasileira pela Casa do Psicólogo (Cunha et al., 1993). A Escala de Maturidade Mental Colúmbia, normalizada por Alves e Duarte em 1993, ainda se encontra fora do mercado.

Existem, contudo, os testes brasileiros. Porém, se é importante que a normalização tenha sido brasileira, o contraponto é que muitos deles datam da década de 50, 60 ou 70, estando, portanto, desatualizadas. Entre eles está o INV (Teste de Inteligência NãoVerbal), concebido em 1951 e considerado, segundo Cunha et al. (1993), "uma das técnicas melhor padronizadas no Brasil" (p.165), tendo se utilizado de mais de 25.000 sujeitos pelo país.

27 Escala Weschler de Inteligência para Crianças. 


\subsubsection{1. - O WISC, emblema da situação nacional}

Sendo "a escala Weschler mais usada no Brasil" (Cunha et al., 1993, p.108), mencionar teste de inteligência para crianças entre nós parece ser sinônimo de mencionar o WISC.

O WISC destina-se a crianças de 5 anos a 15 anos e 11 meses e foi lançado em 1949. No Brasil, esta é ainda a escala utilizada em peso pelos psicólogos, porque, embora antiga, foi a única que teve tradução para o português e adaptação de alguns itens para a realidade brasileira, trabalho realizado em 1964 por Ana Maria Poppovic.

O WISC-R é uma versão revisada do WISC lançada em 1974 e pouquíssimo difundida no meio brasileiro, pois está disponível apenas na versão original americana. O WISC-III constitui a terceira e mais recente geração do WISC, cujo lançamento se deu em 1991 e entre nós sofre do mesmo problema.

O WISC original conta com duas escalas, uma verbal e uma de execução, que são propostas com o fim de avaliar diferentes componentes intelectuais. Como o nome sugere, a escala verbal consiste de subtestes a que o indivíduo responde oralmente e, na de execução, a resposta do sujeito compreende a execução de alguma tarefa, como desenhar a saída de um labirinto, colocar figuras na seqüência correta, armar objetos etc.

Na normalização do WISC, utilizaram-se 2.200 crianças americanas, brancas somente, e 55 "deficientes mentais." (Anastasi, 1972, p.369). A “distribuição das crianças para todo o país obedecia, estreitamente, ao recenseamento de 1940 dos Estados Unidos" 
(p.369), sendo, para essa autora, provavelmente o teste cuja amostra seja mais representativa de seu país como um todo.

Cunha et al. (1993) citam algumas críticas que outros autores fizeram ao WISC. A primeira, em decorrência de a normalização ter sido feita essencialmente com amostras de crianças brancas de classe média (americana), não sendo, portanto, representativa para outros grupos sociais. Nesse sentido, inclusive, o WISC III traz inovações que consideraram a diversidade de "gênero e etnia" (p.211) tanto na atualização de alguns itens como na seleção das amostras de normalização, com o intuito de corrigir falhas do instrumento original.

Além disso, o WISC seria acusado de testar predominantemente “o potencial para o aproveitamento escolar e não o funcionamento social adequado." (Cunha et al., 1993, p.209). No Brasil, há ainda mais uma agravante: além de haver uma diferença encontrada entre o material americano original e o brasileiro no subteste "Armar Objetos", o que pode influenciar o desempenho num grau ainda desconhecido uma vez que não há pesquisas a respeito, não houve normalização no Brasil, mas uma tradução do teste e adaptação de alguns itens. Some-se a isso o questionamento quanto à compatibilidade cultural entre a escala verbal original e a traduzida e adaptada para o Brasil, uma vez que os itens verbais parecem mais suscetíveis às influências culturais e, portanto, até a ordem de dificuldade em que são apresentados poderia modificar o resultado (Cunha et al., 1993). Mello (1998), a esse respeito, ressalta que "a simples tradução do teste para a nossa língua, apesar de permitir uma linguagem unificada quanto às instruções e material verbal, não é suficiente para fazer do 
WISC um instrumento eficiente para medir a capacidade intelectual da criança brasileira." (p.72).

Como chama a atenção Mello (1998) após uma revisão da literatura a respeito das pesquisas nacionais sobre o WISC, embora muitas se utilizem dele, "poucas são as que têm o próprio teste como objeto de estudo." (p.71).

Nesse sentido, destaca-se a importância do estudo de Lemgruber e Paine (Mello, 1998), que introduziram modificações na escala verbal do WISC adaptada por Poppovic e normalizaram-na para a população carioca, a partir de uma amostra de 640 crianças na faixa etária entre 6 e 15 anos, sendo que 325 eram do sexo masculino e 315 do feminino. Tendo ocorrido em 1974, a pesquisa só veio a ter suas tabelas publicadas em 1981, permanecendo pouco divulgada e conhecida entre os psicólogos (Mello, 1998).

Cunha et al. (1993) discutem os laudos forenses, baseados no WAIS (Weschler Adult Intelligence Scale ${ }^{28}$ ), e considera que, dado que o WAIS não teve normalização brasileira, seria "essencial a utilização de outras técnicas para confirmar o resultado." (p.205). Pode-se supor, por extensão, que o mesmo procedimento seja recomendado com relação aos laudos baseados em diagnósticos feitos a partir do WISC e que se destinem a intervenções legais junto à criança, como sua inclusão numa classe especial.

Em suma, a situação dos testes mentais no Brasil é precária, sendo o WISC um caso emblemático: um teste que em seu país de

\footnotetext{
${ }^{28}$ Escala de Inteligência Weschler para Adultos.
} 
origem já está na terceira versão continua sendo utilizado entre nós em sua versão original, datada de 1949. Pior, sem a devida normalização, contando apenas com uma tradução e adaptação de alguns itens, trabalho realizado ainda na década de 60 .

É interessante notar, entretanto, que mesmo nos Estados Unidos os dados do WISC seriam passíveis de interrogações. Anastasi (1972) chama a atenção para o fato de o manual do WISC não discutir a validação do instrumento, deixando o usuário com escassas informações a respeito.

Assim como no caso de Paine e Lemgruber (Mello, 1998), as iniciativas ou os esboços de normalização brasileiros dos testes psicológicos freqüentemente concentram-se no meio universitário e não nas editoras e ainda assim são escassas, como relata Jacquemin (1997).

Os testes são mercadorias vendidas por editoras especializadas, as quais no Brasil temos, principalmente, a Vetor, a Cepa e a Casa do Psicólogo. Provavelmente, o fato de as normalizações serem notoriamente pesquisas caras colabora grandemente para que as editoras não procurem reverter essa precariedade, num país em que até o subteste Labirinto foi pensado como alternativo ${ }^{29}$ na adaptação, para minimizar o tempo e o gasto com o material (Mello, 1998). Porém, nesse sentido, ainda que as pesquisas acadêmicas estejam

\footnotetext{
${ }^{29} \mathrm{O}$ WISC conta com um subteste alternativo para a escala verbal e um para a escala de execução, aplicáveis para o caso de ter-se de invalidar algum subteste da aplicação normal.
} 
longe de atender às reais necessidades da área, será que é justo a universidade financiar o que as editoras deveriam estar?

Vale aqui ressaltar que Anastasi (1972) assevera, ao tratar do código de ética profissional quanto ao emprego de testes psicológicos, que "o autor do teste e o seu editor têm a responsabilidade de rever os testes e suas normas, a fim de impedir a sua desatualização." (p.54).

No entanto, se os testes continuam vendendo, se não há outras opções comerciais e não existe pressão por parte dos psicólogos para que haja normalização dos testes, por que as empresas investiriam nisso? Diante desse quadro, qual seria a responsabilidade das editoras estrangeiras, detentoras dos direitos autorais dos testes, ante a precariedade com que eles estão sendo utilizados aqui? Qual a responsabilidade das editoras nacionais, comercializadoras de instrumentos providos de normas para avaliação sem confiabilidade, do Conselho Regional de Psicologia, na defesa da ética na atuação psicológica e contra os malefícios que uma má atuação pode causar ao cliente, das instituições de formação de psicólogos e, claro, dos próprios psicólogos que utilizam os testes?

Nenhum dos segmentos pode se eximir de responsabilidade. No Brasil, o WISC, bem como outros instrumentos citados e em situação similar, continua sendo comercializado e utilizado - às vezes como critério único de avaliação de indivíduos - tanto por profissionais despreparados e desinformados como por profissionais qualificados, que, com isso, comprometem a vida de seus clientes na forma de 
diagnósticos que não têm nenhum respaldo nem na própria ciência de origem. 


\section{3 \\ CRÍTICAS AOS TESTES}

Vários autores que contestam os testes psicológicos poderiam ser aqui reunidos. Existem aqueles que não se dedicaram predominantemente à questão mas já publicaram suas idéias sobre os procedimentos psicotécnicos, no Brasil e no exterior, como aqueles que se dedicaram especificamente aos testes. Porém, devido à magnitude que uma compilação deste porte tomaria, optamos aqui por selecionar, com destaque, Lawler (1981) e Patto (1993), dada a consistência e representatividade das questões que enunciam. 


\section{1 - Discussões sobre a inteligência no passado: uma ilustração}

Os testes foram criticados sob diversas perspectivas. É interessante observar que as oposições a eles não surgiram apenas mais contemporaneamente, mas vários apontamentos já eram realizados na época da grande expansão dos testes psicológicos nas primeiras décadas do século.

Tal é o caso de uma séria discussão acerca da natureza das medições realizadas por meio do teste de inteligência, retratada por Spearman (1955). No centro da pequena celeuma reproduzida por esse autor estava o conceito de inteligência. Afinal, o que era a inteligência preconizada nos testes? Uma manifestação ou sua essência?

A visão da inteligência dos testes como uma qualidade multiforme arbitrariamente pinçada nos testes estava presente em W. Lippmann:

\footnotetext{
“Os psicólogos nunca conseguiram se colocar de acordo numa definição (da inteligência) (...) O examinador que aplica um teste de inteligência não pode defrontar cada criança com as mil e uma situações que podem se dar no lar, no comércio, na granja, na oficina ou na política, e que requerem o exercício dessas aptidões (capacities) que de forma sintética chamamos inteligência. Passará, portanto, a sondar as habilidades mentais mais abstratas que entram em jogo uma e outra vez. Mediante este rude processo, o examinador da inteligência vai determinando gradualmente que situações da vida real requerem
} 
memória, decisão, engenho etc. Em conseqüência, inventa quebracabeças que possam se aplicar com rapidez e escasso instrumental, a fim de sondar o melhor possível a memória, o engenho, a resolução e tudo o mais. (...) O examinador elabora suas conjecturas na base de um grande número de testes que ele supõe são de inteligência $(\ldots)$ Estas adivinhações pode ser que ponham à prova a inteligência e pode ser que não. Pode ser que só meçam um aspecto da inteligência. Quem sabe?" (Lippmann ${ }^{1}$ apud Spearman, 1955, p.34) ${ }^{2}$.

Há também um caso interessante, narrado na época por Trabue ${ }^{3}$ (apud Spearman, 1955), de uma mulher que, submetida ao teste, obteve um resultado muito ruim. Porém, tornou-se uma mulher de sucesso, "regente de um dos melhores hotéis da Quinta Avenida." ${ }^{4}$ A conclusão irônica de Trabue é: "não obstante o resultado categórico dos testes, insisto que essa mulher é inteligente." ${ }^{5}$ (Trabue apud Spearman, 1955, p.33).

\footnotetext{
${ }^{1}$ Lippmann, W., The new republic. S.I., 1922.

2 “Los psicólogos nunca han logrado ponerse de acuerdo en una definición (de la inteligencia) (...) El examinador que aplica un test de inteligencia no puede enfrentar a cada niño com las mil y una situaciones que pueden darse en el hogar, en el comercio, en la granja, en la oficina o en la política, y que requieren el ejercicio de esas aptitudes (capacities) que en forma sintética llamamos inteligencia. Procederá, por lo tanto, a sondear las habilidades mentales más abstractas que entran en juego una y outra vez. Mediante este rudo proceso, el examinador de la inteligencia va determinando gradualmente que las situaciones de la vida real requieren memoria, decisión, ingenio, etc. En consecuencia, inventa rompecabezes que puedan aplicarse com rapidez y escaso instrumental, a fin de sondear lo mejor posible la memoria, el ingenio, la resolución y todo lo demás (...) El examinador elabora sus conjeturas sobre la base de un gran número de tests que él supone son de inteligencia (...). Estos acertijos pueden que pongan a prueba la inteligencia y puede que no. Puede que sólo midan un aspecto de la inteligencia. ?Quién lo sabe?"

${ }^{3}$ Trabue, J ournal of educational research. S.I., 1922.

4 "Regente de uno de los mejores hoteles de la Quinta Avenida."

5 "No obstante el resultado categórico de los tests, insisto en que esa mujer es inteligente."
} 
Essa argüição mantém-se viva até os dias de hoje, como veremos neste capítulo e no próximo, em que retrataremos diversos questionamentos de que os testes foram alvo.

\section{2 - O argumento do Q.I ., a nova “cara" do racismo americano}

Uma das obras críticas de grande consistência já produzidas exclusivamente sobre testes é a de James Lawler, Inteligência, hereditariedade e racismo, de 1981.

Na realidade, seu trabalho questiona, essencialmente, o teste de Q.I. ${ }^{6}$ e seu uso no sistema educacional americano, para justificar cientificamente diferenças de classe. Esse posicionamento, a propósito, é parecido com o de Patto (1993) no Brasil, que será desenvolvido posteriormente.

Suas preocupações têm como uma das origens o baixo desempenho das "minorias" raciais nos testes, nos Estados Unidos. Contudo, este fato não deve ser tomado, para o autor, fora do entendimento do que seja um teste de inteligência, de que medida é expressa pelo "Q.I." e do momento histórico vivido em seu país.

Segundo Lawler (1981), a escola americana ainda seria racista e segregacionista e o uso do teste de Q.I., longe de ser

\footnotetext{
6 Sempre que se abordar os testes em referência a Lawler (1981), entenda-se testes de inteligência que expressam seus resultados em Q.I.
} 
descompromissado, como idealizam alguns cientistas, ao contrário, serve a interesses de uma classe que se sente ameaçada pelos movimentos sociais e reivindicatórios das minorias que clamam por igualdade. O teste de Q.I. é um instrumento de classe, que espelharia o sucesso da classe média a partir de um formato e um conteúdo que Ihes são familiares. Num momento em que as reivindicações dos negros ganhavam corpo e eles foram conquistando certos espaços sociais, o teste, ao mostrar "cientificamente" seus déficits de inteligência, justificaria a desigualdade social em termos de capacidade intelectual. O desnível próprio de uma sociedade de classes ficaria ofuscado pela constatação científica da incapacidade inata dos oprimidos: "a revivescência do "Argumento do Q.I." está voltada contra o objetivo da igualdade de educação e integração escolar de negros e brancos." (Lawler, 1981, p.123).

O trabalho de Lawler (1981) denuncia o uso dos testes de Q.I. para dar legitimidade científica ao racismo na explicação do insucesso educacional de uma camada da população, inclusive após os programas compensatórios, baseados nos pressupostos da teoria da carência cultural.

Lawler (1981) então se deterá em alguns desmembramentos da constatação acima. Porém, seu objetivo não é “opor-se à mensuração das capacidades humanas, mas criticar as teorias metafísicas e idealistas da inteligência e as concomitantes práticas educativas"

\footnotetext{
7 The I.Q. argument é o título de um dos livros de Jensen que mais sustenta formulações acerca da inteligência como inata, criticado por Lawler em seu trabalho.
} 
(p.251), questionando as abstrações com que a ciência pensa o Q.I., apartado do processo sócio-histórico. Nesse ponto diferencia-se de Patto (1993), bem como pelo fato de fazer uma crítica interna do teste.

Um dos focos do trabalho de Lawler (1981) são as idéias de Jensen sobre a inteligência, pois, a partir do fracasso dos programas escolares compensatórios, Jensen, para quem o conceito de inteligência pode ser satisfatoriamente expresso como Q.I., sustentaria a "inferioridade biológica da inteligência das raças e das classes..." (p.21). Os sistemas compensatórios não poderiam de fato trazer o benefício esperado, visto que a discrepância social para ele é biológica e hereditária (Lawler, 1981).

Para Lawler (1981), entretanto, o que se destaca em primeiro plano nas diferenças de Q.I. entre os brancos americanos e outras "raças" não é a índole genética mas social da desigualdade. As diferenças, que são de classe, são naturalizadas pelo recorte biológico proposto por Jensen.

Lawler (1981) propõe-se examinar a proveniência do resultado expresso em Q.I., por meio de um minucioso exame interno dos testes psicológicos, sua conceitualização e metodologia. Ele objeta o uso da estatística feito por Jensen e seus seguidores, que a tomam de modo absoluto, ignorando o fato de ser produto humano. Nesse sentido, seria preciso saber o que o teste está medindo, “em vez de transformar as técnicas estatísticas num fetiche." (p.27).

Segundo Lawler (1981), o modo como a inteligência é vista nos testes de Q.I. pressupõe seu inatismo e imutabilidade. Na educação, 
contrapõe o autor, em que se tem um grande uso para os testes de Q.I., é que se deveria pensar a inteligência como uma qualidade em movimento e não como um presente fechado que ou se recebe ou não ao nascer.

Ele tenta demonstrar algo que também observa Patto (1993), i.e., como este pressuposto biológico da inteligência está, na realidade, carregado de senso comum mas reveste-se de cientificidade, ganhando respeito por meio de procedimentos científicos que são mal utilizados e mesmo manipulados para corroborar idéias racistas de seus autores, cuja concepção sobre seu objeto de estudo foi formada a priori.

Segundo Lawler (1981), a inteligência nos testes e em Jensen e Eysenck, é entendida operacionalmente: a inteligência é o que os testes medem e não uma "coisa" em si. É importante ressaltar que Lawler (1981) não descarta a relevância da compreensão operacional do objeto, reconhecendo que nem tudo que seja útil para o homem necessitaria ser primeiramente conceituado. Entretanto, se para Jensen e Eysenck a idéia operacional de inteligência utilizada nos testes serviria a contento para basear uma teoria, para Lawler (1981) a conceituação seria fruto do desenvolvimento do pensamento, de seu aprofundamento em relação ao objeto e, portanto, uma etapa.

Lawler (1981), ao examinar o método a partir do qual os testes de Q.I. são elaborados, conclui não se tratar de conhecimento científico, mas de subjetivismo e apriorismo. O primeiro consiste no "primado das idéias (...) sobre a realidade que elas refletem" (p.38), e o segundo, Lawler (1981) define a partir de Engels, 
“consiste em chegar dedutivamente às propriedades de um objeto, a partir do conceito do objeto, em vez de aprender com o próprio objeto. Primeiro o conceito do objeto é formado a partir do objeto; depois dáse uma viravolta e o objeto é avaliado pela sua imagem, pelo seu conceito. O objeto é então obrigado a conformar-se com o conceito, e não o conceito com o objeto." (Engels ${ }^{8}$ apud Lawler, 1981, p.41-42).

A partir destas observações, Lawler (1981) define a ciência dos testes como não científica. A ciência “de fato" não é apriorista, nem subjetivista, nem ideológica, nem deixa preconceitos de classe se interporem a ela. Essa ciência dos testes, entretanto, ofusca a verdade, tal como a divisão social de classes. Por isso, para ele a noção de Q.I. é “a pretensamente científica idéia de Q.I." (Lawler, 1981, p.31). Assim, resultariam necessariamente em ambigüidade as referências científicas ao "conceito" e à "objetividade", em especial em Jensen e Eysenck.

Uma crítica freqüente entre os oponentes dos testes psicológicos feita por Kagan, mencionada por Lawler (1981), é a disparidade cultural entre a população a partir da qual o teste foi elaborado, normalizado e validado e as populações outras que também são submetidas ao teste, muitas vezes prejudicando-se com um baixo resultado. Os testes de Q.I. estariam “imbuídos de predisposições favoráveis a uma dada cultura ou classe." (Lawler, 1981, p.54). Os itens do teste em geral não seriam neutros, o que vale não só para os

\footnotetext{
${ }^{8}$ Engels, Friedrich, Anti-dühring. New York, International Publishers, 1975.
} 
itens verbais (Lawler, 1981), como geralmente se diz. Kagan, segundo Lawler (1981), examina uma situação do cotidiano colocada pela pergunta de um teste: o que você faria se fosse mandado comprar pão e o padeiro dissesse que já não tinha mais pão? A resposta mais inteligente esperada no teste para uma criança de 7 anos seria a de que iria a outro padeiro e a menos inteligente a de que voltaria para casa.

Porém, Kagan pondera que a "resposta inteligente" esperada pressupõe que a criança viva num ambiente cotidiano específico que reúna certas condições: que haja mais de uma padaria por perto, que a criança possa ir andando e em segurança, que sua família não dependa do crédito de um certo estabelecimento ou que, seja por que motivo, seus pais não tenham dado instruções explícitas de retornar à casa caso não haja pão (Lawler, 1981).

Lawler (1981) não questiona a capacidade de mensuração do teste, mas o que o teste de fato mede. Por exemplo, os testes de compreensão de leitura de fato mediriam a "capacidade de ler, a concentração, a memória..." (Lawler, 1981, p.55). Tais capacidades, no entanto, não seriam inatas mas aprendidas e desenvolvidas e estariam em consonância com as condições objetivas históricas de existência da sociedade. O autor cita um exemplo interessante, formulado por Eysenck a partir de uma prova de analogias: 
“[Eysenck] apresenta o seguinte exemplo para distinguir entre um teste de 'aproveitamento' (A) e um teste de 'aptidão' mental ou inteligência inata $(B)^{9}$ :

A. Júpiter está para Marte assim como Zeus está para: Poseidon, Ares, Apolo, Hermes.

B. Preto está para branco assim como elevado está para: verde, alto, baixo, cinzento.

Com certeza, argumenta no fundo Eysenck, ninguém pretenderá que os significados de 'preto' e 'branco' sejam conhecidos apenas de algumas classes sociais, como pode ser o caso do primeiro exemplo. A capacidade para resolver esta analogia é por conseguinte claramente uma questão de exercício de uma capacidade que não exige qualquer instrução especializada." (p.56).

Isso, no entanto, não provaria ser a inteligência inata. Para sustentar tal posição, o argumento teria de conceber a inteligência como capacidade absoluta e invariável que, embora mudasse com a idade, não "evoluiria" verdadeiramente (já que tanto os itens como os resultados dos testes são ponderados conforme a idade. Dessa feita, uma criança que obteve Q.I. 70 aos 6 anos em tese obteria o mesmo resultado aos 10). Assim, a concepção de Q.I. “é geralmente entendida como sustentáculo da idéia de que a inteligência é, basicamente, qualquer coisa com que nascemos e que não muda através de nossa vida." (Lawler, 1981, p.31).

É possível, entretanto, contestar que a psicometria conceba o Q.I. como capacidade inata e basicamente imutável em

9 Eysenck, The I.Q. argument: race, intelligence and education. Illinois, The Lybrary Press, 1971, p.50. 
Anastasi $^{10}$ (apud Lawler, 1981). Para ela, “nenhum teste pode fazer mais do que medir o comportamento. Se tal comportamento pode servir como indicador efectivo de outro comportamento só se pode determinar pela experiência empírica." (p.101).

A tese de Lawler (1981), contudo, é a de que o inatismo e a imutabilidade seriam uma noção implícita da formulação do Q.I. O autor chama a atenção para o fato de haver aprendizagem direta e indireta dos exercícios formais de pensamento que são exigidos nos subitens. O fato de alguns subitens não fazerem uso direto de conteúdo formal escolar não implica que para nele obter-se êxito não haja a necessidade de aplicar o que é indiretamente ensinado nas matérias escolares. Ele refere-se a uma forma de exercitar o pensamento que não nasce pronta no indivíduo, necessitando ser desenvolvida - no caso de Analogias, embora em B faça-se uso de conceitos que não são "escolares" (discernir preto do branco), a forma de resolvê-lo implica um exercício de pensamento que Lawler (1981) questiona se não seria muito estimulada ao se aprender aritmética.

O apriorismo, subjetivismo e ideologia que sustentam metodológica e conceitualmente o teste de Q.I. seriam históricos e teriam feito parte da psicometria desde seu início. Para Lawler (1981), seria importante analisar os testes de Galton, Binet e Terman para compreender o imbricamento entre o racismo e o Q.I. de seu tempo.

O primeiro passo seria compreender as causas do fracasso de Galton. Segundo Lawler (1981), está no reconhecimento do próprio

\footnotetext{
${ }^{10}$ Anastasi, A., Psychological testing. New York, The MacMillan Co, 1961.
} 
Galton de que seus testes sensoriais não mediam a inteligência, pois os melhores escores eram conseguidos por pobres e não por ricos, a denúncia de seu apriorismo:

\begin{abstract}
“... há, desde o princípio do movimento para medir a inteligência por meio de testes, uma tentativa coerente de elaborar um teste que fizesse parecer plausíveis certos conceitos apriorísticos sobre a inteligência. Desde o princípio houve uma tentativa de provar que a inteligência é uma capacidade biologicamente fixada que é encontrada em diferentes proporções através da sociedade, de modo que se pode dizer que a classe alta é inatamente superior em inteligência às classes 'baixas' e que os colonialistas brancos são inatamente superiores em inteligência às raças não brancas sobre as quais procuram preservar o seu domínio." (p.62).
\end{abstract}

Em outras palavras, Jensen não seria uma novidade mas uma reedição de noções históricas nos testes de Q.I.

Binet, na concepção de Lawler (1981), era mais pragmático que Galton na elaboração de testes de inteligência. Embora mais complexos que as provas de Galton, os testes de Binet ainda assim não escaparam do apriorismo e da falta de cientificidade. Eles incluíram o que o senso comum entendia como inteligência ou ser inteligente. Por exemplo, um dos métodos de Binet para selecionar os melhores itens dos testes era requerer aos professores e diretores das escolas que selecionassem nas classes crianças que fossem, em sua opinião, médias (Lawler, 1981).

Mesmo que no caso de Galton as "preferências de classe" (Lawler, 1981, p.69) tenham sido mais explícitas, o teste de Binet 
ainda não tinha em conta a raiz social da desigualdade de classes que se refletia no resultado do teste. A escolaridade era desconsiderada como fator importante para um bom resultado no teste e a medida da inteligência fornecida pelos testes era tida como absoluta. Haveria

“... indiretamente no teste um preconceito de classe na medida em que as aptidões e atitudes escolares do aluno executante 'bem-sucedido' propendem a ser ajudadas pelas condições sociais e educacionais das crianças da classe média e de famílias com profissões liberais em muito maior grau do que pelas crianças das famílias operárias (...) filhos de certos imigrantes e das crianças oriundas de minorias racial e nacionalmente oprimidas." (p.69-70).

Para Lawler (1981), o “teste de inteligência elaborado por Binet é $(\ldots)$ essencialmente um reflexo do êxito das crianças no trabalho escolar." (p.70).

Binet era mais cauteloso quanto a afirmações de denotação racial e da imutabilidade da inteligência, o que não parece ser o caso de Terman, para Lawler (1981). Em algumas passagens citadas por este último, Terman mostra-se propenso à explicação da diferença racial para justificar os baixos resultados de mexicanos e hispanoíndios. As atitudes sugeridas por Terman para com este grupo mostram pouca crença no aspecto social da mente. Estas incluiriam segregação em turmas especiais na escola - embora o prognóstico seja a de chegarem a no máximo bons operários - e desautorização para reproduzirem-se, como medida eugênica (Lawler, 1981). Além disso, alguns procedimentos adotados na elaboração do Stanford-Binet 
parecem impregnados de noções de darwinismo social (Lawler, 1981), como a validade por grupos contrastantes, em que foram selecionados como sujeitos homens de negócio versus desempregados e alunos de liceu versus adolescentes delinqüentes. Conforme argumenta Lawler (1981), contrastar esses grupos para validar o teste pressuporia que a vida "já teria selecionado" os melhores.

Para Lawler (1981), o Stanford-Binet é um teste de aproveitamento e não de inteligência, classificando a mensuração da inteligência como "sondagem de opinião relativa à inteligência." (p.83). Uma opinião mais representativa, porém não "mais verdadeira em si própria." (p.83).

Lawler (1981) também examina o fundamento dos procedimentos de validação dos testes, questionando a pretensão de se apoiar num critério independente do teste para afirmar, ou não, o atributo medido. Isso porque o critério nunca é neutro, mas social. Por exemplo, usar o desempenho na escola sem levar em conta que existem escolas boas e ruins, tratamentos diferentes a bons e maus alunos etc., ou então, comparar crianças "normais" a crianças "institucionalizadas" pelo método de grupos contrastantes.

É importante mencionar que Lawler (1981) diferencia Anastasi das posições acima relatadas. Ela contesta a possibilidade de isenção de cultura num teste, como também critica a falta de rigor com que muitos testes foram lançados no mercado.

Lawler (1981) não nega o componente biológico que as capacidades humanas possuem. Contudo, ele não existiria à revelia das forças sociais e históricas. Ao contestar o entendimento de 
Eysenck sobre a alfabetização como um processo quase isento de cultura, Lawler (1981) escreve que

\begin{abstract}
“um fenômeno tal como a alfabetização e o subseqüente desenvolvimento do pensamento lógico-formal pode ser explicado sem a hipótese de uma qualquer mutação radical nos genes. Isto não equivale a dizer que o pensamento alfabetizado não redunde nalguma forma de reorganização do sistema nervoso humano, e não pressuponha essa possibilidade no cérebro - que já se tinha transformado em correspondência com o desenvolvimento dos símbolos artificiais, da linguagem, como fatos básicos na separação da espécie humana dos primatas superiores." (p.111).
\end{abstract}

Para Lawler (1981), se a inteligência ou o domínio de certas formas de pensamento são históricas e não puramente biológicas, pode-se "ensinar a pensar." (p.116). O que não autorizaria a dizer que a correlação entre o resultado “nos testes de 'raciocínio abstrato' formal e o aproveitamento nas disciplinas escolares" (p.119) seja falsa. No entanto, embora o poder de mensurabilidade de algo do teste de inteligência não possa ser questionado, como ele é construído em bases do que o autor considera não científico, “apenas por causalidade poderiam fornecer informações clínicas úteis acerca da 'substrutura intelectual' de um indivíduo." (p.119).

Lawler (1981) irá igualmente problematizar o conceito de "populações". Contrapondo-o à visão de Marx (Uma contribuição para a crítica da política econômica) a respeito, Lawler (1981) argumenta que este conceito de população pressuporia uma homogeneidade que é 
falsa numa sociedade de classes. Ele não se opõe aos procedimentos estatísticos, "desde que se baseiem em categorias e em leis do desenvolvimento cientificamente delineadas." (p.186). Seu exemplo recai sobre as médias estatísticas: "o conceito de médias não se aplica à interação de forças qualitativamente opostas." (p.188).

A matemática seria um instrumento e não deveria tomar o lugar da "análise conceptual básica mas tem de subordinar-se a esse conhecimento real." (p.188).

Em resumo, os testes estariam sobrecarregados de uma visão de classe, que teria caminhado da alta classe, em Galton, até a classe média. O teste é segregacionista em sua "estrutura (...) e (...) conteúdo." (p.123), reproduzindo preconceitos de classe. Reproduzindo cegamente essa visão de mundo e carregados de senso comum, os testes perdem seu caráter verdadeiramente científico. A estatística Ihes emprestaria a aparência de ciência, embora a interpretação dos resultados alcançados fossem, essencialmente, ilusionismo a partir dos números, "truques de prestidigitação", como menciona repetidas vezes.

Lawler (1981), combatendo a noção da ciência como a esfera da pura idéia que não está atada ao mundo de onde surgiu, ressalta o compromisso da ciência com os homens e o quanto as idéias geram práticas: "esta ilusão da independência na busca do conhecimento só agrava a sujeição das instituições de atividade intelectual aos poderes práticos: os interesses da classe dominante, que dispõem das idéias que os cientistas e os universitários propõem." (p.252). 


\section{3 - A psicometria na justificação do fracasso escolar}

No Brasil, há vários pesquisadores que criticaram o uso de testes, em especial os de inteligência. Alguns propuseram novas formas de avaliação, como se verá adiante.

Um trabalho importante é o de Patto (1993), A produção do fracasso escolar.

Sua crítica também parte de um marco teórico materialista dialético, assim como Lawler (1981) e algumas asserções são semelhantes, mas não se pode considerá-los indistintamente.

Primeiramente, é preciso compreender que o marco teórico do materialismo dialético não é homogêneo, havendo diferenças internas. Partir desse referencial não significa discordância a priori dos métodos utilizados pelos positivistas e pelos mesmos motivos.

Vygotsky, que propôs o estudo dialético do desenvolvimento da mente, incluiu pesquisas experimentais. Seu método próprio diferenciava-se do que a ciência experimental de então praticava, visando “(1) uma análise do processo em oposição a uma análise do objeto; (...) (2) (...) uma análise explicativa e não descritiva; e (3) uma análise do desenvolvimento que reconstrói todos os pontos e faz retornar à origem o desenvolvimento de uma determinada estrutura." (Vygotsky, 1991, p.74). Contudo, o que ele pretendia do método era informação objetiva e palpável sobre os fenômenos internos, tornados visíveis ao serem transformados em comportamento - o que por vezes 
levou a uma má interpretação de seu pensamento como neobehaviorismo ${ }^{11}$ :

\begin{abstract}
“Entendemos que nosso método é importante porque ajuda a tornar objetivos os processos psicológicos interiores; os métodos de associação entre estímulos e respostas são objetivos, limitando-se, no entanto, ao estudo das respostas externas já contidas no repertório do sujeito. (...) Somente a 'objetificação' dos processos interiores garante - acesso às formas específicas do comportamento superior em contraposição às formas subordinadas." (p.85).
\end{abstract}

Lawler (1981), por seu turno, não é contrário à mensuração das qualidades humanas, como ficou claro em vários momentos da breve apresentação que fizemos de suas idéias.

Patto (1993) não toma o teste psicológico como objeto central de seu estudo. Antes, seu foco volta-se para a compreensão do fenômeno da multi-repetência e da evasão nas escolas públicas brasileiras. A partir disso, sua análise inclui uma visão crítica dos instrumentos psicológicos de medida, especialmente sua imbricação histórica com a escola, que se perpetua até a atualidade na forma de psicodiagnósticos de alunos com problemas escolares.

Ainda, Patto (1993) não critica internamente os testes, concentrando-se essencialmente nas relações externas que estes mantêm. A psicometria, ou o movimento de uso dos testes psicológicos, é analisada como uma resposta científica que tem, 
historicamente, fins ideológicos de mascaramento de uma estrutura social cuja injustiça desponta por meio de "desadaptações" individuais.

Tal mecanismo encontraria um fértil terreno na escola, sobre a clientela de baixa renda, evidenciado no alto índice de fracasso escolar nessa população, o que não seria casual e tampouco poderia simplesmente ser computado a déficits individuais captados pelos testes de nível mental.

A psicologia ocuparia espaços na escola, incumbindo-se de dar conta de problemas que a pedagogia não conseguiu, sem, contudo, pensar o fenômeno do fracasso escolar numa perspectiva educacional crítica, repetindo a pedagogia nesse ponto.

Tal fato não se deveria, entretanto, a nenhum movimento explícito por parte de educadores ou psicólogos de coadunação com forças dominantes, para manutenção da dominação, como ressalta Patto (1993). Dever-se-ia ao movimento próprio da ideologia, que, em sendo aparentemente verdade, necessitaria de um esforço crítico para desvelar-Ihe a falsidade. Nesse sentido, a reprodução desse estado de coisas se daria muitas vezes por meio da ingenuidade de quem, freqüentemente imbuído de boas intenções, coloca-se acriticamente diante da realidade.

Ao longo de sua história, a psicometria, com a preocupação de mensurar funções psicológicas dos indivíduos, alia-se e ao mesmo tempo é produto da psicologia que estuda a diferença entre os indivíduos, a psicologia diferencial. Como pano de fundo, a inclinação para mensurar as diferenças evidenciar-se-ia num momento histórico em que, conforme Patto (1993), a promessa liberal de igualdade social 
não consegue mais se sustentar, diante de uma estrutura social injusta que deixou a sua margem um grande contingente populacional. A "detecção científica dos normais e anormais, dos aptos e inaptos" (Patto, 1993, p.38) viria ao encontro da necessidade de justificação social frente a essa situação. De acordo com essa autora, a quantificação das capacidades dos indivíduos desviaria os questionamentos acerca da estrutura social, que permaneceria intocada, e voltaria a problematização ao indivíduo para tentar compreender por que uns estão incluídos e outros excluídos dos benefícios de uma organização social e econômica que surgiu da promessa de igualdade, liberdade e fraternidade. Questionava-se a sociedade; a ciência teria apresentado a resposta em termos das diferenças dos indivíduos. A questão política e econômica ter-se-ia diluído, em parte, no campo da saúde e da educação.

Nessa perspectiva, os testes psicológicos seriam, consoante Patto (1993), um instrumento de classe, de justificação e manutenção do mundo tal como ele é. O teste, em seu formato e conteúdo, apresentaria e representaria valores da classe dominante. Uma das formas de perpetração desse corpo de idéias que é a ideologia seria a psicometria, na medida em que a própria ciência instituída se revelaria como ideologia. Em sua lógica lacunar, a ciência-ideologia se caracterizaria por falar a verdade (e nisso consiste sua aparência de verdade), mas nunca até o fim, deixando lacunas que, quando pensadas, mostram sua falsidade. Desse modo, o fato de o teste atingir com diagnóstico de subdotação essencialmente as crianças pertencentes a grupos sociais historicamente vitimizados por uma 
visão estereotipada e preconceituosa por parte da classe dominante e, de outro lado, de superdotação ou normalidade via de regra os indivíduos pertencentes a estratos elevados da pirâmide social, tem de ser desvelada. Estes resultados não são "naturais" e devem ser problematizados, na medida em que, efetivamente há, antes de mais nada, uma diferença material concreta entre ambos os grupos que é histórica, bem como o são a discriminação e a exploração que incide sobre os primeiros.

O conceito de inteligência dos testes, por exemplo, compreenderia o que fosse inteligência ou um comportamento inteligente dentro da classe dominante. Por isso, crianças pobres, embora inteligentes, apareceriam como deficientes, pois o instrumento não daria conta de captar outras manifestações desta qualidade que estivessem fora de seus padrões (Patto, 1993).

Patto (1993) aprofunda a relação da teoria da carência cultural americana e sua aplicação no Brasil e analisa o impacto que tais idéias tiveram entre nós, permanecendo até hoje. Existiriam três marcas fundamentais na teoria da carência cultural: preconceito contra pobres, etnocentrismo e uso de métodos de pesquisa mais avançados cientificamente, que reveste as outras duas características.

Segundo a autora, após a Segunda Guerra e a derrocada dos projetos racistas e etnocentristas do Eixo, os argumentos racistas explícitos que vinham sendo usados na ciência até então causariam constrangimento se aplicados tal como antes, para explicar a perpetuação de uma parcela da população em desigualdade de 
condições sociais e econômicas, contrariando a velha promessa burguesa de igualdade.

A teoria da carência cultural surge num momento em que eclodem, nos Estados Unidos, movimentos reivindicatórios das chamadas "minorias" pela prometida igualdade. O desenvolvimento sadio da criança, tanto do ponto de vista físico como psíquico e cognitivo, é tomado em relação a fatores como estimulação ambiental, boa alimentação e maturação orgânica. O organismo, ao interagir com o meio e vice-versa, vai se formando. Entretanto, aponta Patto (1993), valores, crenças, hábitos, costumes, normas e habilidades típicos das classes dominantes são considerados os únicos adequados à promoção de um desenvolvimento psíquico, físico e cognitivo sadio.

As explicações sobre o sucesso escolar e profissional desigual, com a teoria da carência cultural, passam a fundamentar-se em preconceitos e estereótipos com uma fachada científica rigorosa. Pesquisadores totalmente alheios à falibilidade e precariedade dos instrumentos, como explicita Patto (1993), vão a campo pesquisar "o pobre", alvo histórico do preconceito, "visto como elo de ligação entre o selvagem e o civilizado - o depositário de todos os defeitos" (p.49), já baseados na crença da incompetência generalizada dos sujeitos e da pobreza como frutificadora apenas de defeitos e incapacitações. A ciência legitimaria práticas e olhares recheados de estereótipos e preconceitos que, antes, continham-se, essencialmente, no senso comum (Patto, 1993).

Em síntese, embora Lawler (1981) e Patto (1993) tenham uma série de diferenças entre si, destaca-se o entendimento do teste como 
instrumento de classe, no qual o bom ou mau desempenho do indivíduo não pode ser computado exclusivamente à sua "inteligência" mas a mediações sociais que atravessam e vão para além da testagem.

O próprio conceito de inteligência preconizado nos testes foi argüido pelos autores apresentados e, tanto em Lawler (1981) como em Patto (1993), foi correlacionado com a aprendizagem e desempenho escolar de uma certa classe, indicando que o atributo medido no teste - inteligência - deve ser reconsiderado.

Nos Estados Unidos assim como no Brasil, o fracasso quase que sistemático das classes baixas nos testes de Q.I. é apontado como parte de uma "lógica" que visaria, entre os americanos, barrar o progresso da igualdade de negros e outras "minorias", revivendo a justificação genético-racial para a desigualdade social. No Brasil, os testes em geral, em especial os de inteligência, teriam um uso parecido, constituindo uma rede de práticas e idéias que culpabiliza o indivíduo pelo fracasso escolar e isenta o sistema social. 


\section{4 \\ ATUALIZAÇÃO DO DEBATE}

Neste capítulo, realizou-se uma pesquisa bibliográfica a fim de que se pudesse ter uma ilustração da discussão atual sobre os testes psicológicos em nosso meio.

Foram escolhidos, para isso, quatro periódicos nacionais, além de outros textos aleatórios considerados importantes. Como nesta dissertação é dada maior ênfase à utilização dos testes no meio escolar, dois desses periódicos pertencem à área da educação, quais sejam, os Cadernos de Pesquisa e o Educação e Sociedade ${ }^{1}$. Os outros dois são

${ }^{1}$ Os Cadernos de Pesquisa foram fundados em 1971 e são vinculados à área educacional da Fundação Carlos Chagas. A partir de 1997, sofre uma mudança editorial que amplia formalmente seu escopo para questões de raça e etnia. O Educação e Sociedade, ligado à Faculdade de Educação da Unicamp, surgiu em 1978 assumindo o compromisso de 
publicações especializadas em psicologia, notoriamente mais vinculadas ao emprego de instrumentos de avaliação, os Arquivos Brasileiros de Psicologia e o Boletim de Psicologia².

Nas análises, procurou-se destacar três elementos: o que se repete, o que mudou e o que aparece como inédito na discussão acerca do uso de testes psicológicos no âmbito da escola.

\section{1 - Temas que se repetem}

Não obstante as inúmeras mudanças ocorridas na área, desde o surgimento dos testes psicológicos até os dias de hoje, é importante notar a repetição de certos temas e, mais importante que isso, de certas formas de pensamento no emprego e na crítica ao uso de testes. Isso significa que, muito embora as transformações não possam ser negadas, especialmente nas condições concretas de inserção dos testes, como o trabalho e a educação, em seus pressupostos mais íntimos, a menção aos

debater criticamente a teoria e prática educacionais. Chegou a ter importantes autores reproduzidos, como Adorno, Habermas, Gramsci, Hegel, Kant ...

2 Os Arquivos Brasileiros de Psicologia são uma publicação do ISOP - FGV, instituição ligada à pesquisa em psicometria. Foram fundados em 1944 sob o nome de Arquivos Brasileiros de Psicotécnica, por Mira y López, sendo este seu primeiro diretor. Mudou de nome em 1949 para Arquivos Brasileiros de Psicotécnica, em 1969 para Arquivos Brasileiros de Psicologia Aplicada e finalmente ganhou seu nome atual em 1978. O Boletim de Psicologia, inaugurado em 1949, é editado pela Sociedade de Psicologia de São Paulo, que vem contando com uma série de professores vinculados às técnicas de exame psicológico em seu corpo diretor. 
testes por vezes continua arraigada a ideários que, acreditava-se, estariam superados.

Isso mostra com visibilidade a força com que certas concepções de mundo e de homem se perpetuam e o caráter puramente ideológico de alguns empregos que ainda se faz dos testes.

Em relação a temáticas, a que, indubitavelmente, se repetiu com freqüência foi a avaliação de alunos que não conseguem acompanhar o aprendizado formal. Não obstante de uma forma diferente, como se verá posteriormente, a mesma clientela continua em foco: aquela dotada dos chamados distúrbios ou problemas de aprendizagem. E a psicologia continua trazendo produções para esse campo, tal como foi apontado anteriormente em Lawler (1981) e Patto (1993). Observa-se nos artigos que, a exemplo do que verificou esta última autora, o trabalho psicológico que se utilizou de testes é voltado para o indivíduo com problemas, seguindo-se basicamente um modelo clínico privado de atuação nas instituições escolares.

No entanto, como será apontado adiante, parte da crítica a esse modelo, que propõe novas formas de avaliação do educando, rompendo com a psicometria, parece não haver conseguido quebrar alguns dos pressupostos criticados.

Portanto, apesar de esforços em contrário - e considerando-se que a grande maioria dos trabalhos voltou-se para a classe social de menor poder aquisitivo -, os problemas relativos à aprendizagem da clientela de 
baixa renda das escolas continuam presentes, assim como a avaliação psicológica e uma série de noções históricas.

\subsection{1 - O que se repete no campo de uso de testes}

Dentre os ideários que se repetem estão, principalmente, a reprodução do "monadologismo" do indivíduo, a naturalização das relações sociais e, em menor grau, a teoria da carência cultural.

O "monadologismo" encontra-se intocado em grande parte dos trabalhos, aprofundando o "individualismo" das práticas institucionais inspiradas em modelos privados.

O entendimento do indivíduo como mônada é algo que Adorno atribui a Freud, mas que pode se aplicar também a certas vertentes da psicologia. Nesse sentido, no seio da contradição da mônada, se o a priori desse fazer psicológico é acrítico, é ainda por meio dele que é possível a crítica e o fazer em psicologia.

Dada essa peculiaridade, não foi surpreendente constatar em quase todos os trabalhos psicológicos que se pesquisou que o esforço crítico não pôde - quando existente - romper a barreira auto-imposta pela própria psicologia.

Neles, as dimensões afetivo-emocional e/ou cognitiva do indivíduo foram tomadas em si mesmas, sem que houvesse discernimento quanto ao fato de os recantos internos do indivíduo abrigarem também a 
totalidade e, neles, poder-se captá-la de um modo muito particular: introjetada, "apartada" da sociedade.

Essa crítica faltou aos trabalhos psicológicos, ao passo que abundou a retratação das dimensões internas que terminaram hipostasiando o sujeito psíquico. As pesquisas focando o indivíduo com problemas em seu processo de escolarização, como dificuldades de aprendizagem e, em menor escala, dificuldades de comportamento, e em suas figuras próximas de referência, como os familiares e/ou professores, não conseguiram transcender a visão de indivíduos ou sistemas de indivíduos que não integram uma totalidade. Não obstante a abrangência para a família, para a escola ou para o meio social, a marca dessas conceituações é que os elementos, "em crise" ou não, são tomados como instâncias que apenas - ou no máximo - se relacionam entre si, recortadas de suas outras mediações.

Pelos artigos lidos, por um lado, há consciência por parte de alguns psicólogos de que seja necessário considerar outros dados, além do indivíduo sobre o qual está a queixa, como frisa Santos (1990) ao apontar os malefícios de se tomar a criança como "única fonte de problemas." (p.93). Por outro, esses outros elementos são tomados na relação com o indivíduo com problemas cindidamente - criança-mãe, criançaprofessora, criança-coleguinhas, criança-meio - reproduzindo uma 
tendência ambientalista antiga, apontada por Patto (1993) e surgida em oposição ao organicismo ${ }^{3}$, datada da época da expansão da psicanálise.

Duarte (1995) propõe, em termos pedagógicos, a "estimulação da criança, através de abordagens individual e social." (p.16). É difícil entender o que a autora quer dizer com abordagem social de estimulação. Além disso, na idéia de "estimulação" da criança circunscreve-se o princípio monadológico que atribui ao indivíduo e à sociedade o papel de sistemas relativamente fechados e autônomos.

Desta feita, quando autores da área de testes referiram-se ao contexto social, suas interpelações não avançaram dos problemas emocionais (Santos, 1990) ou cognitivos decorrentes de carências nutricionais (Golfeto e Loureiro, 1989), afetivas e ambientais (Borges e Loureiro, 1990) ou de estimulação (Duarte, 1995).

Mesmo o crescimento da avaliação qualitativa e o uso de testes projetivos, que se ancoram, em grande parte, na psicodinâmica e exprimem uma mudança de eixo nas técnicas de exame psicológico, não garantem que o reducionismo que se atribuiu à quantificação tenha sido abandonado.

Borges e Loureiro (1990), por exemplo, utilizam o Desenho da Família com História, mas "jargonizam" uma série de conceitos psicodinâmicos. Golfeto e Loureiro (1989) lançam mão de vários recursos

3 Embora, segundo Patto (1993), o organicismo e o ambientalismo tivessem sido de alguma forma conciliados, pela psicologia educacional brasileira, não obstante suas grandes diferenças. 
diagnósticos, desde exames médicos até entrevistas com pais, testes mentais e projetivos, mas tamanha coleta de dados não impediu que suas conclusões fossem preconceituosas, simplistas e recheadas de termos técnicos que, utilizados de forma "curta e grossa", parecem desvinculados de seu objeto.

Marconi e Graminha (1992), ao lerem relatórios de diagnósticos psicológicos de ingresso nas classes especiais, concluem terem aparecido inúmeras avaliações de personalidade com asserções "muitas vezes enfatizando características negativas ou dificuldades da criança e mediante a utilização de termos técnicos que podem ser totalmente desconhecidos, ou, pior, erroneamente interpretados pelos professores." (p.154).

Esses fatos demonstram com clareza que incluir outros elementos à análise não necessariamente a ampliará ou instaurará uma forma realmente nova de pensar a questão.

O enfraquecimento ou ausência do pensamento dialético na psicologia contou também com outro forte componente, a naturalização. A redução das forças sociais a um princípio natural, por sua vez, mostrou uma forte influência da epistemologia genética de Piaget.

A tensão subjacente à socialização do homem é formalizada por meio das idéias de auto-regulação ao meio e do desenvolvimento em platôs, do qual participam a inovação e a conservação. Para o positivismo, a naturalização e a conseqüente planificação da tensão é um 
ponto essencial, pois funda-se opondo-se a elas (Marcuse, 1988; Horkheimer e Adorno, 1991).

Desta feita, o modo como o indivíduo está se "auto-regulando" ao meio e às mudanças que ele impõe, para entender a aprendizagem e suas dificuldades, ou sua "evolução" simbólica, é o parâmetro na comparação entre o que é "sadio" e o que é "desviante", em autores como Oliveira (1997).

Oliveira (1997) refere-se ao desenvolvimento como "processo evolutivo" (p.37). A noção de um processo de maturação e de autoregulação organísmico, emprestado da biologia, supõe um desenvolvimento linear e uma troca harmônica do organismo com o ambiente até em sua desestabilização.

É perceptível em Galdo (1989) e em Oliveira (1997) o suposto implícito de uma sociedade harmônica na qual o indivíduo que tem um desenvolvimento mental saudável e equilibrado o será também. Essa idéia naturalizada de saúde mental, aparentemente, não requer um grande esforço epistemológico por parte dos autores para se sustentar, uma vez que se insere na lógica em que o normal é o saudável e o saudável é o natural.

A harmonia do indivíduo, portanto, entraria em sintonia com a harmonia social. Conforme evidenciou Patto (1993), vê-se aqui repetir nessas produções psicológicas direcionadas à escola a noção de que problemas, distúrbios e desadaptações sejam patologias, intercorrências individuais, geralmente frutos de questões ambientais ou familiares num 
processo que, se transcorrido "normalmente", não apresentaria perturbações. Assim, os distúrbios seriam a exceção dentro de um todo equilibrado.

Miranda (1995), ao discutir criticamente a epistemologia genética de Piaget, aponta vários de seus elementos que entram em consonância com as características conceituais aqui depreendidas dos artigos pesquisados. O entendimento piagetiano de inteligência, por exemplo, constituir-se-ia em um "processo adaptativo" que sintetizaria "em um único conceito (...) uma categoria racional e outra biológica." (p.329).

No sentido piagetiano, o desenvolvimento ocorreria segundo mecanismos de auto-regulação do organismo e a inteligência, concebida na "continuidade da ação biológica à ação mental" (Miranda, 1995, p.331), seria um conceito em que "não há oposições, conflitos, contradições, mas apenas desequilíbrios passageiros que logo se converterão em novas auto-regulações." (p.330).

Além da naturalização e do empirismo, característicos do modelo piagetiano de inteligência, haveria uma ênfase no indivíduo, uma vez que a inteligência seria formulada em vista de mecanismos do indivíduo (Miranda, 1995).

A ausência de um pensamento social mais consistente pode estar ligada ao fato de que, na teoria piagetiana, forma e conteúdo se separam nas estruturas lógicas de pensamento (Miranda, 1995). Conforme critica Marcuse (1967), as estruturas de pensamento lógico-matemático, que 
sustentam o método científico, são tomadas em Piaget como fato biológico no homem, tendo seu caráter histórico ignorado:

\begin{abstract}
“A interpretação de Piaget reconhece o caráter prático interno da razão teórica, mas o extrai de uma estrutura geral de ação que, em última análise, é uma estrutura hereditária, biológica. O método científico assentaria finalmente numa fundação biológica que é supra- (ou antes, infra-) histórica. (...) admitindo-se que todo conhecimento científico pressupõe a coordenação de ações particulares, não vejo por que tal coordenação seja 'por sua própria natureza' lógico-matemática..." (p.156).
\end{abstract}

Outra vertente da aplicação das idéias piagetianas encontrada nos artigos pesquisados foi o uso das provas piagetianas, em Visca (1997).

Carneiro e Ferreira (1996), entretanto, que apontam um crescimento no uso das provas piagetianas aplicadas comparativamente e de acordo com a psicologia diferencial, consideram a avaliação psicométrica e a psicogenética "duas linhas de investigação tradicionalmente antagônicas" (p.79). Nesse sentido, Corrêa e Moura (1991) asseveram que o uso psicométrico das provas operatórias, sendo "fruto de uma prática consensual" (p.27), romperia com o princípio teórico que as sustenta.

Note-se que a naturalização tem sido um princípio da psicometria. Entretanto, o que se percebeu foi que, ao serem aplicados, os instrumentos psicométricos não foram discriminados da "naturalização 
social" e, em vez de servir como um meio de combatê-la, corroborou a impotência diante dela.

Por exemplo, quando se externa a preocupação com os problemas de adaptação da criança à escola (Santos, 1990; Duarte, 1995; Borges e Loureiro, 1990), essa não deixa de ser uma problemática legítima. No entanto, a adaptação escolar, tomada como o caminho natural, leva a desadaptação a parecer perturbação do bom andamento do processo normal. E os testes acabam sendo empregados para avaliar e reverter essa desadaptação, assim concebida.

Miranda (1995), a respeito de uma tentativa de alguns autores de trazerem mais o "social" à abordagem piagetiana - embora em nosso caso isso não se restrinja aos piagetianos -, ressalva que se deve verificar se essas tentativas não estariam somente agregando um ponto externo a elas, sem de fato problematizarem os princípios que fundamentam e prescrevem a prática educacional.

Vista dessa forma, portanto, a "inclusão do social" estaria condenada à autolimitação do modelo teórico implicado. Apenas se estaria emprestando a esses novos objetos incluídos as mesmas categorias, sem conseguir transcender a atribuição pontual, individual e imediata que se dá aos conceitos.

Quando o Q.I. é tomado por Galdo (1989) como a expressão imediata da inteligência de crianças de um orfanato, o método está sendo naturalizado. Isso não significa, em nosso entender, que, sem negar-Ihe seu valor, o modelo não possa ser rompido; parece, no entanto, que o 
esforço teórico e prático requerido para tal, ainda está longe de acontecer.

Quanto à teoria da carência cultural, Patto (1993) refere-se a ela como preconceito disfarçado de ciência. Um preconceito e um etnocentrismo históricos contra os indivíduos da classe pobre, revestidos de procedimentos científicos que Ihes dão aparência de verdade.

De fato, um dos principais motes das explicações para os déficits encontrados nas crianças avaliadas pelos autores foi a pobreza. Mas, se, por um lado, há uma percepção por parte deles, mesmo que tênue, das condições difíceis de vida que a pobreza impinge aos indivíduos, por outro, a trilha volta-se à detecção dos "males" psicológicos e, por vezes, físicos que a pobreza teria causado, freqüentemente de forma etnocêntrica e sem um caminho para a crítica social, como já foi dito, voltando a análise à compreensão das dinâmicas individuais, familiares e do meio.

A criança pobre é vista como uma constante deficitária. Como todo preconceito, desconsidera seu objeto, apriorizando-o: a pobreza financeira é também a priori cultural, ambiental, psíquica, cognitiva...

Golfeto e Loureiro (1989) fornecem o melhor exemplo disso. A desqualificação das crianças pobres que pesquisaram, dotadas de "baixo nível sócio-econômico-cultural" (p.102), ocorreu por diversos meios. Desde seu ambiente e nutrição pobres, estruturação familiar "típica" (p.108), carência afetiva até a ignorância dos pais. 
O texto é repleto de expressões características da teoria da carência cultural. A irracionalidade do discurso é, dessa forma, tão patente que é o caso de se perguntar como ele ainda se mantém.

Passagens que deixam clara a evolução da pobreza financeira para a pobreza cultural e ambiental, o etnocentrismo e o preconceito de classe seriam perfeitamente refutáveis, como em:

“... povos subdesenvolvidos são doentios porque, sobretudo, têm hábitos de higiene e alimentação, noções a respeito de saúde, método de prevenção e cura, condições, habitações, um modo de vida, enfim inadequado, errôneo, incorreto, que acaba facilitando a disseminação da doença e até abreviando a vida" (p. 107),

ou em:

“... a subcultura impede que os sujeitos pertencentes a nível sóciocultural baixo se enquadrem em um processo de adaptação. A pobreza dos estímulos ambientais torna essas crianças mais passivas a elas, conseqüentemente, tendem a lutar menos para a integração social. Têm dificuldades de buscar o aprendizado, e a escola é mais um local onde podem obter alimentação [negritos nossos]." (Golfeto e Loureiro, 1989, p.107-8),

Entretanto, como preconceito que é, a teoria da carência cultural é difícil de ser desmontada se não se apontar, à guisa do que sugerem Horkheimer e Adorno (1973c) em relação ao discurso nazista, as 
configurações psíquicas que sustentam esse apego à irracionalidade. Ou seja, a adesão ao discurso, que o faz poderoso não obstante sua fragilidade, torna-se mais necessário do que voltar-se ao discurso propriamente dito.

Nesse sentido, fica claro que os testes psicológicos são mais um elemento que instrumentaliza a irracionalidade.

\subsection{2 - O que se repete na crítica aos testes}

Embora seja um modo diferente de repetição, é necessário perceber que a crítica aos testes, por vezes, deixou-se apreender pelas mesmas categorias que está criticando.

Vários elementos levam a isso: o desconhecimento dos preceitos internos do teste, a crítica ideológica, que em alguns momentos desconsidera as mudanças históricas ocorridas em seu objeto bem como as condições que o criaram, focando as relações externas que se mantêm com ele, e a desconsideração da importância da pesquisa quantitativa e dos métodos tipológicos, para ficar entre os principais.

$\mathrm{Na}$ análise do encontro da educação com a saúde que Collares e Moysés (1989) realizam, as autoras refutam a idéia comumente difundida de que a desnutrição da classe pobre seja motivo significativo para o fracasso escolar, como comumente se vê associar. Os testes de Q.I., de acordo com elas, foram muito utilizados nas pesquisas que teriam comprovado problemas de desenvolvimento em crianças desnutridas. 
Porém, ao não atentarem para o fato de que o teste não é neutro, os pesquisadores teriam utilizado como grupo de controle das crianças desnutridas, originárias em sua maioria dos estratos econômicos baixos, crianças não desnutridas, provenientes de classe econômica média e alta da mesma localidade ou mesmo de países diferentes das desnutridas, resultando daí a diferença nos escores, em favor das não desnutridas.

Todavia, as próprias autoras fornecem elementos suficientes para que se conclua o contrário do que concluíram. Ou seja, de que o problema não foi o uso ou não de testes de Q.I., mas pesquisas mal feitas, ou, no mínimo, equivocadas, sendo flagrante o descuido com as amostras. Numa pesquisa séria, as diferenças de população são e devem ser levadas em conta.

Bem como Lawler (1981) e Patto (1993), Moysés e Collares (1997) e Collares e Moysés (1989) discordam da neutralidade apregoada do teste, afirmando que a mensuração da inteligência participa do ponto de vista de uma classe. Dessa feita, "avaliar o desenvolvimento de uma criança através de um instrumento padronizado em outra classe social é, antes de tudo, não respeitar esta criança, seus valores, seu estrato social." (Collares e Moysés, 1989, p.80-1). Entretanto, conforme já se discutiu, a neutralidade do teste é falsa não por ser ele um instrumento de classe, pois a produção de conhecimento sempre será o ponto de vista de um grupo social, seja a sociedade dividida em classes ou não ${ }^{4}$. A não

\footnotetext{
${ }^{4}$ Caso contrário, a superação da divisão em classes tornaria a ciência neutra?
} 
neutralidade do teste se deve ao fato de o conhecimento científico ser sempre voltado para os interesses humanos, substituindo a verdade pelos procedimentos. Nessa intencionalidade reside a dominação cega, violenta e manipulatória da natureza.

Mas, segundo Moysés e Collares (1997), muito embora a inteligência medida no teste não seja absoluta e universal, a suposta neutralidade e objetividade do teste seriam seu passaporte para a universalização. Isso seria um procedimento declarado e até "propagandeado" por seus divulgadores:

“... [o teste seria] um instrumento que se pretende neutro, objetivo e, portanto, aplicável a qualquer homem, em qualquer espaço geográfico, temporal e social. Os testes de inteligência, sempre permeados de valores dos grupos sociais dominantes, são divulgados como podendo ser aplicados a qualquer homem, não importa se rico ou pobre, vivendo próximo ao Central Park, em Nova York, ou na zona rural de Sertãozinho. Estudando em colégio de elite em São Paulo ou sendo filho de bóia-fria, e já cortador de cana... Detalhes como esses, para quem quer acreditar, não são relevantes, pois se está avaliando a inteligência, que transcenderia a própria vida [negritos nossos]." (p.84).

São, contudo, afirmações errôneas sobre os princípios metodológicos dos testes. Não se pode, de fato, normalizar um instrumento para uma população e aplicá-lo em outra (cf. Anastasi, 1972). Mas, quando isso acontece e mesmo assim os resultados são 
considerados cientificamente válidos, é preciso pensar o que está produzindo essa absolutização.

É nesse sentido que serão consideradas as críticas de Machado (1996) aos testes, que não serviriam para avaliar os casos de queixas escolares cristalizadas por traduzirem os desempenhos dentro da lógica do método positivista:

\footnotetext{
“Parece que os testes psicológicos têm nos cegado. Eles não servem para avaliar o campo de forças no qual as crianças, os psicólogos, os professores se inserem, de forma a podermos intervir nas relações. A neblina invade o campo político, histórico, afetivo." (p.30).
}

A autora acaba corroborando a petrificação do teste, do mesmo modo que aqueles que o empregam o fazem, ao crer que a avaliação por meio de testes só possa se dar de uma determinada maneira: cristalizada, absolutizada, descompromissada e naturalizada. E que, de um certo modo, essas sejam categorias dos testes repassadas às relações que se mantêm com a queixa na escola, e não características da totalidade nas quais os testes se incluem. Isso se estende em parte também a Bizzo (1995), autor da área educacional que comenta, à luz da história da eugenia, o enquadramento dos testes na naturalização dos fenômenos humanos, a partir da captação de dados numa curva.

É criticada a idéia de objetividade do teste, que, para se constituir, necessitaria transformar o outro em objeto e o próprio sujeito em objeto. Moysés e Collares (1997) propõem avaliar as capacidades da criança sem 
a padronização e o método tradicionais, que são substituídos por uma observação das atividades do dia-a-dia da criança. A avaliação padronizada é dispensada pois submeteria o sujeito ao que ela saberia testar. A proposta das autoras iria no sentido inverso, de a avaliação conseguir se fazer sobre o que a criança sabe e não sobre o que ela não sabe.

$\mathrm{Na}$ realidade, trata-se de uma avaliação qualitativa, que usa a subjetividade do pesquisador como elemento a mais de avaliação, para compor a informação objetiva, o que necessariamente a tornaria mais difícil e requereria pessoas altamente capacitadas (Moysés e Collares, 1997). Por vias diversas, ficam aproximadas a crítica aos testes e sua aceitação, uma vez que há propostas diagnósticas que vão igualmente nessa linha qualitativa, fazendo uso, no entanto, de testes psicológicos.

Nessas propostas não psicométricas, incluindo-se Machado (1996), a falta da padronização não comprometeria a validade e objetividade de seu método, uma vez que "a subjetividade se coloca não pelo instrumento, mas pelo pesquisador enquanto [sic] homem, ser social." (Collares ${ }^{5}$ apud Machado, 1996, p.124).

É importante perceber aqui que, dialeticamente entendidas, subjetividade e objetividade não são tidas como "instâncias" que se opõem mas, antes, como campos que se interpenetram. Ainda que de forma invertida, a visão acima exposta pelas autoras termina partilhando 
da maneira cindida como o método positivista trata sujeito e objeto: enquanto o positivismo reafirma a "objetividade", essa sua crítica, em oposição, assevera a "subjetividade".

Cabe questionar, porém, se propostas como essas superariam a nocividade que se crê estar depositada nos testes psicológicos. Isso porque propostas novas, até opostas aos testes, podem ser integradas ao mesmo corpo de idéias que os sustenta, repetindo as mesmas relações criticáveis. A rigor, qualquer método e qualquer teoria estão sujeitos a apropriações dessa espécie (Cf. Merani, 1977, e Carone, 1995).

Além disso, as propriedades psicométricas dos instrumentos padronização, normas, precisão e validade - visam, ao contrário do que se pensa, colocar limites a eles. A questão na utilização de testes é, portanto, de outra ordem, como já debateu e se retomará também nos próximos capítulos.

No caso dos psicodiagnósticos, que são rejeitados pelos críticos aos testes em vista das características atribuídas aos instrumentos já elencadas, Amiralian (1995), adepta do diagnóstico compreensivo ${ }^{6}$, indaga se o problema seriam eles ou sua má qualidade e a má formação do psicólogo:

5 Collares, C.A.L., O cotidiano escolar patologizado. Campinas, SP, Tese (Livre Docência), Faculdade de Educação da UNICAMP, 1994.

${ }^{6}$ Diagnósticos compreensivos são psicodiagnósticos clínicos, baseados em Walter Trinca, segundo Amiralian (1995), que buscam nos testes dados não apenas quantitativos para comporem sua hipótese diagnóstica sobre o sujeito, ao lado de outros procedimentos, não necessariamente psicométricos. 
“Como podemos pensar em um diagnóstico eficaz se poucos sabem o que realmente é a deficiência mental? Na maioria dos cursos de Psicologia o que se aprende sobre a criança deficiente mental é que é aquela que apresenta Q.I. abaixo de 70. Como podemos dizer que o problema é do diagnóstico quando um jovem psicólogo rotula a criança de deficiente mental quando ela apresenta desempenho em um teste equivalente a Q.I. 65?" (p.38).

Amiralian (1995) critica o fato de se diagnosticar a deficiência mental ainda predominantemente de acordo com o modelo médico ou psicométrico. No médico, o uso de testes objetivaria realizar aferições a fim de fornecer subsídios ao médico ou asseverar suas conclusões, que salientariam as distinções patológicas do indivíduo. No modelo psicométrico, partir-se-ia do pressuposto teórico de que haja diferenças constitucionais de origem genética e imutável no comportamento, e a utilidade dos testes estaria em “identificá-las, classificá-las e medi-las." (p.38) .

Embora a questão dos psicodiagnósticos seja, de fato, mais ampla do que sua má qualidade e a formação do psicólogo, ao evidenciá-la Amiralian (1995) mostra que nem sempre o uso de testes é tão acrítico a si mesmo.

Não obstante, é nítida a importância de muitas análises e propostas que os trabalhos críticos aos testes trazem. É fundamental a denúncia do 
que vem acontecendo nas classes especiais ${ }^{7}$ para deficientes mentais em São Paulo como lugar de segregação, na qual a maioria dos alunos termina encerrando a vida escolar, cristalizados nas relações institucionais, condenados ao ostracismo sob o rótulo da deficiência mental e às vezes da loucura (Machado, 1994).

O questionamento desse rótulo e a proposta de movimentação da queixa dentro da instituição, como trazida por Machado (1996), é um passo importante para a psicologia escolar, do mesmo modo que a evidência exposta por essa autora e Moysés e Collares (1997) de que uma mesma criança que tenha sido classificada como deficiente mental leve por um teste de inteligência mostre comportamentos "inteligentes" em seu dia-a-dia. Tendo em vista o papel decisivo que os testes mentais ainda têm no ingresso de um aluno na classe especial, pesquisas como estas são importantes para ajudar as crianças que estão sendo depositadas nessas classes.

Collares e Moysés (1989) aludem com clareza a "afinidade ideológica entre educação e saúde" (p.84) pela incorporação, por parte da primeira, de questões pertinentes à segunda. Isso se daria "transformando os grandes problemas sociais em questões individuais,

\footnotetext{
${ }^{7}$ Conforme Machado (1994), segundo a “Resolução SE n.o 247 de 30/09/86, elas são '... classes com objetivo de atendimento educacional especializado para portadores de deficiência auditiva, física, visual, mental (grau leve) e superdotados... Só poderão ser atendidos pela Educação Especial os alunos caracterizados como excepcionais por profissionais credenciados..." (p.12). Esses profissionais são eminentemente psicólogos, no caso da deficiência mental, visto que o grau leve é definido pelo Q.I.
} 
culpabilizando as pessoas por suas doenças $e$ isentando de responsabilidades o sistema social." (p.84).

Nesse sentido, apesar das críticas de que são passíveis, é inegável a contribuição das obras aqui apresentadas para uma melhor compreensão dos problemas escolares.

\section{2 - 0 que mudou}

De acordo com os dados coletados na pesquisa aqui realizada, a quantificação e a psicometria clássica encolheram.

Vários indícios encontrados nos artigos levam a isso: predomina a ênfase nas dinâmicas internas do indivíduo, de suas relações com a família e o "meio", concomitantemente à avassaladora recorrência a análises qualitativas dos testes e diagnósticos compreensivos, além de um grande emprego de projetivos. Há ainda uma significativa falta de investimentos nos instrumentos psicométricos (criação de novos e normalização dos já existentes) e a quase total ausência do termo "psicometria" e similares nos artigos.

É muito interessante perceber que os testes psicológicos, produtos históricos do experimentalismo, abundaram na abordagem de aspectos afetivos e cognitivos baseados na psicodinâmica e na epistemologia genética e escassearam na abordagem experimental e cognitivista. Nessa 
linha, contou-se apenas com Capovilla et al. (1997), que verteram para o computador vários instrumentos, Bzuneck (1996), que aplica uma escala comportamental e partilha da teoria da aprendizagem social-cognitiva de Bandura e Fonseca, Santos e Cruz (1994), que avaliam o sucesso de um programa compensatório cognitivista promovido em Portugal por meio de uma série de instrumentos psicométricos. Tal fato evidenciaria uma mudança ocorrida nos paradigmas psicológicos em voga quanto aos problemas escolares na atualidade?

Dentre os artigos pesquisados, apenas o de Capovilla et al. (1997) mencionou explicitamente que sua proposta se tratava de psicometria, o que se aplica inclusive ao I e o II Encontro de Técnicas de Exame Psicológico, registrados no Boletim de Psicologia. Não apareceram termos como "avaliação psicométrica", "psicometria" ou "avaliação por testes", tendo predominado as nomenclaturas "avaliação psicológica", "exame psicológico" e "psicodiagnóstico". Além disso, chama a atenção o já aludido rebatizado dos Arquivos Brasileiros de Psicologia, outrora Arquivos Brasileiros de Psicotécnica. Oliveira (1997) durante o II Encontro de Técnicas de Exame Psicológico, inclusive, critica indiretamente o procedimento tradicional de avaliação por testes ao questionar a mera quantificação, preferindo a avaliação qualitativa.

Há, igualmente, uma mudança quanto à "objetividade" da técnica como um valor quase "em si" em Anastasi (1972), em contraposição à discrição com que essa característica foi tratada nos artigos. Duarte (1995), aliás, assume o uso de um procedimento que considera 
"subjetivo" (p.10) para valorar o nível de desempenho escolar dos sujeitos, justificando-o como melhor do que os tradicionais métodos, tendo sido já utilizado por outros autores.

Isso posto, somado à colocação de Franco (1990), explicitada no Capítulo 2, de que a matriz epistemológica subjetivista de avaliação escolar tenha crescido, dentro da escola, como uma resposta à matriz objetivista, em especial nos anos 70, nos leva a concluir que, de algum modo, o questionamento sobre os métodos "objetivos" de conhecimento psicológico atingiu a psicometria. A alusão a métodos mais qualitativos de ajuda na compreensão da dinâmica interna do sujeito pode ter sido uma resposta à crítica que os métodos quantificadores de avaliação estavam recebendo, expressa pelo recuo verificado de alguns de seus baluartes. Entretanto, como será desenvolvido no capítulo seguinte, a avaliação qualitativa não assegura que o processo seja mais humano bem como a quantificação não representa apenas barbárie.

A investigação qualitativa da subjetividade foi, por vezes, agregada à quantitativa e, por vezes, foi sua substituta. A preocupação meramente quantitativa foi encontrada apenas em Capovilla et al. (1997), mas estes autores não trabalharam diretamente com questões escolares.

Isso não significa que a aferição de índices deixou de ser empregada, como se percebe em Duarte (1995 e 1997), Loureiro et al. (1994), Machado et al. (1994) e Graminha (1996). Mas ela foi menos ou tão importante quanto o recolhimento de dados do processo, tanto na abordagem da personalidade como da cognição. 
Conforme Carneiro e Ferreira (1996), os testes psicológicos teriam começado a sofrer muitas críticas fundamentalmente por sua "falta de base teórica explicativa do constructo que pretendem avaliar." (p.56). Jacquemin (1997) é também crítico quanto à qualidade de muitos dos instrumentos desenvolvidos no apogeu da psicometria após a Primeira Guerra, o que teria contribuído para os desgastes e até rejeições que eles receberam.

Existem basicamente duas funções diferentes que se pôde depreender para os testes. Uma é a tradicional provisão de índices confiáveis que demonstrem a situação mental do indivíduo. A outra é, além dos números, o alcance de dados do sujeito diante de determinadas situações (estabelecidas nas provas dos testes) por meio dos quais o psicólogo possa ter mais subsídios para avaliá-lo, tal como em Galdo (1989) e Rubiano (1992). Ou, ainda, pelo diagnóstico compreensivo e similares (Golfeto e Loureiro, 1989; Amiralian, 1995; Guzzo, 1995; Grassano, 1997).

Nesse sentido, Grassano (1997) afirma que o diagnóstico será útil se conseguir ser ligado contextualmente ao indivíduo, transcendendo a mera informatividade, e Guzzo (1995) propõe que este se encarregue de questões que vão além da medição de qualidades, tendo a participação de pais e professores, sendo interdisciplinar, contendo um aspecto preventivo e não apenas remediativo, estratégias de intervenção em nível familiar e escolar (sala de aula) e, por fim, acompanhando e reavaliando a criança. Esse último ponto é importante tendo-se em vista que, 
conforme Machado (1994) e Marconi e Graminha (1992), a maioria das crianças de classe especial nunca foi reavaliada e acompanhada.

Para Amiralian (1995), o Q.I., obtido por meio do WISC, é apenas um dado a mais na investigação. Em seu trabalho, diagnosticar a deficiência mental constitui-se em "um processo longo e complexo, no qual o quociente intelectual, obtido através da aplicação de testes de nível mental, é apenas um dado de um conjunto maior, que deve ser qualitativamente analisado e incluído no conjunto dos elementos obtidos." (p.43).

Como foi dito, a busca por dados qualitativos deu outra importância à quantificação, mas esta continuou sendo empregada. Entretanto, a notória precariedade dos instrumentos nacionais trazem mais elementos à discussão. A maioria dos artigos não informa ao leitor que as normas utilizadas não eram adequadas (atuais e nacionais).

A diminuição de pesquisas brasileiras sobre testes na década de 70 e o pouco interesse universitário nessa área, retratada por Jacquemin (1997), acarretam problemas adicionais para a prática psicométrica brasileira. Esse autor comenta os resultados da pesquisa de Hutz e Bandeira ${ }^{8}$, que debruçaram-se sobre periódicos nacionais no recorte de 1987 a 1992 com o intuito de analisar a tendência no uso de teste no período. Os dados levantados apontariam, segundo Jacquemin (1997), “uma situação extremamente precária no Brasil, tornando o trabalho do 
psicólogo brasileiro em psicodiagnóstico extremamente difícil e problemático (inclusive do ponto de vista ético) (Hutz, ${ }^{9}$ 1989)." (p.59).

Seria desnecessário elencar todos os autores que se utilizaram de testes psicológicos sem dados normativos adequados pois todos os autores o fizeram, com exceção de Galdo (1989), Capovilla et al. (1997) e Jacquemin (1997), que citam o desenvolvimento de instrumentos e/ou pesquisas de normalização. Cabe ressaltar apenas que Loureiro et al. (1994), bem como Amiralian (1995), mostram atenção para com o fato, Rubiano (1992) menciona que não há normalização mas apenas tradução para o português dos testes que aplica e Carelli (1994) trabalhou com escores brutos e análise de variância sobre suas médias.

A displicência com a adequação das normas dos testes empregados foi um dado preocupante levantado pela pesquisa que, na realidade, só vem confirmar o que se vê na prática.

Como já foi apontado anteriormente, o caráter de fetiche dos testes revelam, nesse caso, sua força total. Além disso, esse apego irracional mostraria a ideologia contemporânea, cuja cegueira está ligada ao desvanecimento do próprio pensamento e não se desfaz facilmente por meio de argumentos racionais.

\footnotetext{
8 Hutz, C.S. e Bandeira, D.R., Tendências contemporâneas no uso de teste: uma análise da literatura brasileira e internacional. Psicologia: Reflexão e Crítica. n.6, 1(2), p.85101, 1993.

9 Hutz, C.S., Avaliação psicológica em psiquiatria: procedimento fundamental ou auxiliar diagnóstico? In: Simpósio no XIX Congresso Brasileiro de Neurologia, Psiquiatria e Higiene Mental. São Paulo, 1989.
} 


\section{3 - O que há de inédito na discussão}

Na pesquisa aqui realizada, embora importantes análises tivessem sido feitas e se tenha verificado uma mudança de enfoque no emprego de instrumentos psicológicos, nenhum dos trabalhos pareceu transcender as concepções historicamente vinculadas a eles, seja no sentido da crítica, seja em sua aceitação. 


\section{5 \\ PARÊNTESES PARA REPENSAR OS TESTES PSICOLÓGICOS: \\ DIÁLOGOS COM A TEORIA CRÍTICA DA SOCIEDADE}

Se para Marcuse (1967), conforme se viu, a técnica está em seus pressupostos ligada à dominação, e por isso não pode transcendê-la, para Horkheimer e Adorno (1973b) é nesta contradição que estaria o germe de sua superação. No pensamento de Horkheimer e Adorno (1973a e 1973b), os mesmos instrumentos científicos que desumanizam ao mesmo tempo apontam para a liberdade ante a desumanização. A consciência da contradição inerente à técnica ou qualquer outra expressão particular de uma totalidade que é 
contraditória mostra um caminho que não vai simplesmente negar qualquer validade dos métodos que se referem ao dado imediato, mas tampouco aceitar tacitamente seus usos e aplicações. O caminho proposto por eles foge do relativismo ou da ingenuidade: "diante da investigação sociológica empírica, é tão necessário o conhecimento profundo dos seus resultados quanto a reflexão crítica sobre seus princípios." (p.122).

A essas e outras considerações é que se voltará a seguir.

\section{1 - A quantificação da subjetividade}

Começar-se-á abordando um traço característico dos testes psicológicos muito criticado por seus oponentes, que é o fato de quantificar a subjetividade ${ }^{1}$.

Mesmo entre os defensores dos testes, este ponto ainda parece ser paradoxal, como se viu em Anastasi (1972) e em Terman e Merrill (1966). Esses autores, ao considerarem favoravelmente a riqueza da aproximação examinador-examinando num teste, observam que com isso a objetividade científica ficaria arriscada.

Claro que, se esse conflito é notável em Anastasi (1972) e em Terman e Merrill (1966) - e outros inúmeros casos poderiam ser também citados - ele certamente não é casual. Há um reconhecimento

\footnotetext{
${ }^{1}$ Sempre que a objetividade ou a subjetividade forem referidas dentro da obra ou contexto da psicometria, entenda-se que se trata da sua conceptualização positivista, que difere da noção dialética, como já explicitado no Capítulo 2.
} 
de que o encontro entre pessoas traga conhecimento de uma em relação à outra, mas fica patente a ameaça que a aproximação traz, necessitando ser totalmente controlada para não sair dos limites gerenciáveis. Isso também não é casual. O horror mítico encontra uma via para emergir na proximidade do particular.

Os esforços para eliminar a subjetividade, entendida conforme preconiza o positivismo, nem sempre conseguem evitar seu escape, mesmo que o pesquisador ignore o fato. Como se mostrou, a própria Anastasi (1972) admite a influência da subjetividade na testagem, ressaltando-se a do próprio examinador, dedicando muitas páginas a esse assunto. Com outras palavras e equalizando o problema a seu modo, a objetividade é colocada a seus leitores na seguinte passagem: “na prática, não se obtiveram padronização e objetividade perfeitas; (...) essa objetividade é, pelo menos, o alvo de criação dos testes e foi conseguida em grau razoavelmente elevado, na maioria dos testes." (p.30)

\section{Diante disso, o que é melhor? A riqueza da aproximação} entre sujeito e objeto ou a objetividade do distanciamento?

Na verdade, há duas implicações na questão acima: a suposição de que a avaliação qualitativa seja, necessariamente, próxima e um embate entre métodos qualitativos e métodos quantitativos, colocados como disputantes do mesmo espaço e, assim, incompatibilizados entre si.

Quanto à primeira, Merani (1977) mostra como é possível lançar mão de métodos qualitativos para fins de dominação. 
A indústria, segundo ele, teria passado a utilizar testes projetivos, considerados "nobres" por muitos na psicologia pelo fato de haverem sido inspirados pela psicanálise e referirem-se à natureza interna do indivíduo, propiciando uma abordagem mais qualitativa que os testes e inventários, digamos, mais francamente psicométricos.

A preocupação da indústria estaria em captar não mais os aspectos cognitivos dos trabalhadores apenas, mas também seu perfil psicológico, por meio da "intenção". O objetivo é o controle de futuros problemas: “a intenção é algo que se determina como conduta no futuro; (...) conhecer determinadas intenções é evitar que determinados atos se concretizem." (Merani, 1977, p.26).

Os testes projetivos teriam ganho importância nos processos seletivos por fornecerem meios de se chegar a essas "intenções", pois

\footnotetext{
“é importante conhecer profundamente a personalidade dos operários

e empregados, mais útil do que conhecer suas qualificações profissionais. (...) a capacidade dos que trabalham é secundária. E uma das principais preocupações do regime é a de precaver-se contra o rebelde potencial." (Merani, 1977, p.31-2).
}

Horkheimer e Adorno (1973a) discutem a contraposição que se faz entre a objetividade empírica e a profundidade ou riqueza teórica no artigo "Sociologia e investigação social empírica.". A contribuição desses autores a esse respeito parece-nos fundamental neste momento, uma vez que foram duros críticos das condições sociais, dotados de uma aguda percepção da realidade, ao mesmo tempo em que realizaram alguns estudos empíricos, sendo certamente A 
personalidade autoritária, em que Adorno participou, o mais amplo deles.

As questões levantadas pelos autores, embora se refiram diretamente à sociologia, são pertinentes à psicologia, dado que seu objetivo é discutir a pesquisa empírica e teórica nas ciências do homem.

Horkheimer e Adorno (1973a) convidam o leitor a abandonar o preconceito e a desconfiança contra a estatística, e alertam quanto ao perigo de se sucumbir a "uma certa atitude de superioridade aristocrática" (p.125) ante os métodos quantificadores. E, da mesma forma que chamam a atenção para o risco de se prender no superficialismo com o método empírico, ponderam que “a mediação dos fenômenos sociais no espírito e através da consciência do homem não autoriza a reduzir, sem mais nem menos, os fenômenos sociais a um princípio espiritual." (p.126).

Os autores mencionam, ainda, o método empírico na sociologia, que persegue a exatidão e a objetividade, inspirado nas ciências naturais e para o qual a quantificação é fundamental, como garantia da repetição do fenômeno e, portanto, da possibilidade de generalizar os resultados obtidos. De outro lado, as críticas a esse método alegam que, na busca da quantificação do objeto, perde-se a compreensão mais aprofundada sobre ele (Horkheimer e Adorno, 1973a).

$\mathrm{Na}$ realidade, este embate poderia ser também traduzido em outra pergunta: o que é mais importante, conhecer o objeto em sua universalidade ou em sua particularidade? 
A resposta continua a mesma, i.e., o conhecimento de ambos são importantes, na medida em que abordam o objeto diferentemente. É tão importante conhecer o fenômeno em sua extensão como em sua profundidade (Crochik, 1998). É um erro sobrepô-los de modo que conflitem entre si. Segundo Horkheimer e Adorno (1973a), é de origem qualitativa o conhecimento mais profundo do objeto. Em geral, é a pesquisa do particular que vai fornecer à pesquisa do universal suas hipóteses, sendo o elo entre o uso da estatística e sua pertinente relação com outros conteúdos.

A quantificação, no entanto - e aí enquadram-se os testes psicológicos -, é acusada de coisificar as qualidades, padronizando-as e reduzindo-as artificialmente, mutilando e violentando o particular. Tal acusação, todavia, é descabida, pois atribui ao instrumento a responsabilidade por um fenômeno social que o inclui, mas o transcende, tornando-o o bode expiatório da desumanização insuportável a que estamos todos submetidos e reproduzindo. O instrumento se submete a ela e a reproduz na mesma medida em que outras vertentes da vida social. A coisificação, mutilação e violentação do homem são reais e (infelizmente) não podem ser atribuídas ao instrumento em si; a luta contra a dominação é mais difícil do que parece.

O imbricamento dos instrumentos quantitativos com a dominação, antes de descartá-los na tarefa de combatê-la, pode fazer deles grandes aliados na medida em que conseguem captar como poucos sua extensão na superfície do real (Horkheimer e Adorno, 1973a): 
“Na medida em que a vida contemporânea está, em grande parte, padronizada, em virtude da concentração do poder econômico, levada a um grau extremo, em que o indivíduo é muito mais impotente do que quer admitir, os métodos padronizados e, em certo sentido, desindividualizados, tanto constituem uma expressão da situação concreta como um instrumento adequado para a descrever e entender." (p.125).

Os testes psicológicos, em sua especificidade, seriam importantes para mostrar como os indivíduos estão ou, antes, o que estão podendo ser.

Relacionado a esse aspecto, não se pode deixar de mencionar o objetivo, no uso de métodos empíricos nas ciências humanas, de equiparação destas com as ciências naturais. No empenho de "limitarse a dados exatos e seguros" (Horkheimer e Adorno, 1973a, p.124), ao conceberem um modelo de ciência idêntico às ciências naturais mas cujo objeto é diferente, as ciências humanas terminam naturalizando fenômenos que não são da ordem natural. Ao perseguir o objetivo da “validade indiscutível" arrisca "restringir-se, precisamente, ao que não é essencial." (p.124).

A crítica à abordagem positivista na psicologia, contudo, que alega que esta psicologia estaria naturalizando relações que não são da ordem da natureza, deve levar em conta também que as relações sociais encontram-se hoje mais naturalizadas do que a consciência queira reconhecer e que, portanto, em última instância, não podem ser atribuídas aos instrumentos: 
“Na objeção habitual à investigação social empírica, isto é, de que seria
excessivamente mecânica, rudimentar e carente de espírito, a responsabilidade por esse estado de coisas é transferida do objeto para a ciência que o estuda [negritos nossos] ..." (Horkheimer e Adorno, 1973a, p.126).

Observe-se que, ao pretender uma psicologia da dimensão físico-natural, uma gama de inquietações que os dados poderiam suscitar fica metodologicamente sem resposta, porque nesta perspectiva os dados "são o que são". E o desenvolvimento positivista tornou a ciência expert nisso. É importante pensar a extensão na totalidade; por isso, poder contar com ferramentas de parâmetros universais. Porém, deve-se pensar por que é que, junto aos fatos, os fatores não são investigados; por que um método que consegue dar conta da superfície é tão sedutor a ponto de tornar-se absoluto. Enfim, por que "o progresso da razão instrumental coincide com a regressão do humano à categoria de coisa." (Silva, 1997, p.23).

O mesmo se aplica ao recurso a uma operação necessária aos instrumentos de mensuração, a tipologia. Tipificar significa classificar os indivíduos de acordo com seus traços, organizando-os segundo tipos (por exemplo, ansiosos e não-ansiosos, lentos e rápidos etc.).

A tipologização, sendo uma redução, não deixa de agredir os espíritos mais refinados, ao perceberem que a particularidade do ser foi resumida a alguns traços no intuito de facilitar a captação das informações. Culpa-se o instrumento que dela faz uso ou, antes, a postura científica de buscá-la e incentivá-la. 
Na realidade, contudo, a questão se revela de outra forma. Se é verdade que a ciência, ao se utilizar da tipificação termine por “incentivá-la”, não é apenas isso. Dadas as parcas condições que a cultura atualmente oferece para a individuação do sujeito, a redução dos indivíduos a tipos antes de ser uma violência do método, é, tal qual a naturalização, uma forma realista de investigação de um fenômeno para o qual não se deve calar (Adorno, 1965).

A separação dos sujeitos em tipos é uma violência da realidade. Ao ressoá-la, o método estaria reapresentando a violência social por meio do instrumento.

A redução das pessoas a rótulos, uma das maiores críticas que se faz aos testes psicológicos, não é algo que se deva cobrar deles. O empobrecimento do homem é um fato e tem raízes históricas:

\begin{abstract}
“Se existem aqueles que pensam segundo rótulos, isso se deve unicamente aos processos sociais subjugadores, obscuros, estandardizadores, 'rotulantes', que praticamente não deixam ao 'indivíduo' liberdade de ação nem verdadeira individuação, que determinam esse modo de pensar. De tal maneira, se estabelece um novo ponto de partida para a tipologia. Temos razões para buscar tipos psicológicos porque o mundo está tipificado e 'produz' diferentes 'tipos' de pessoas. Apenas mediante a identificação dos traços estereotipados do homem moderno e não negando sua existência pode se contrariar a tendência perniciosa para a classificação e agrupação gerais." ${ }^{2}$ (Adorno, 1965, p.698).
\end{abstract}

\footnotetext{
2 "Si existem quienes piensam en rótulos, ello se debe únicamente a que los procesos sociales sojuzgantes, oscuros, standardizados, 'rotulantes', que prácticamente no dejan al índividuo' libertad de acción ni oportunidad de verdadera individuación, determinam este modo de pensar. De tal manera, se establece un nuevo punto de partida para lá tipología. Tenemos razones para buscar tipos psicológicos porque el
} 
Comentando a posição de Adorno sobre o uso de tipos na psicologia em A personalidade autoritária, Crochik (1998) lembra a reificação histórica em que o objeto está mergulhado, concluindo, desta forma, que "não é ao método que é devida a redução do objeto." (p.83).

Para Adorno (1965), a opressão deixa sinais. A divisão da sociedade em classes, a repressão e a hierarquização marcam os indivíduos, em seu pensar, agir e comportar. Uma objetivação dessas marcas é a redução do indivíduo, sua real divisão em tipos. Note-se que para entender esse fenômeno é preciso compreender que o indivíduo não é anterior à cultura. O indivíduo não é "atingido" de fora para dentro pela sociedade mas se compõe a partir dela, no momento em que a introjeta, adaptando-se a ela por sobrevivência, tornando seus (particularizando) os universais da cultura (Crochik, 1998). Assim, estudá-lo é estudar também a cultura e a sociedade nas quais se insere. Por isso a psicologia é privilegiada, ao dispor de meios para apreender a dominação de dentro do sujeito, mas apenas se não excluir uma teoria da sociedade e a filosofia (Crochik, 1998).

O teste psicológico, visto por este aspecto, ao contrário de emprestar categorias reducionistas ao objeto, está apreendendo sua redução.

É importante esclarecer que o uso da tipologia visa dinamizar a pesquisa, aproximando-a da realidade. Desse modo, a proposta de

mundo en que vivimos está tipificado e 'produce' diferentes 'tipos' de personas. Sólo mediante la identificación de los rasgos estereotipados del hombre moderno y no negando su existencia, puede contrarrestarse la perniciosa tendência a la clasificación 
Adorno (1965) não é a de um agrupamento em tipos de cunho "estático-biológico" (p.697) ou segundo critérios meramente estatísticos ou ideais (Adorno, 1965). O autor ressalta a qualidade de algumas tipologias já produzidas por Freud e Jung e comenta, ironicamente, que "nem todas as tipologias são sistemas tendentes a dividir o mundo em branco e preto." ${ }^{3}$ (p.697),

Ainda assim, a redução não deve ser aceita sem críticas. Ao assumir a redução dos indivíduos a tipos, a tipologia deve ter como objetivo sua conceitualização e combate e não sua aceitação incontinenti.

Os testes psicológicos podem servir como um ponto de partida para uma melhor compreensão do indivíduo, inclusive quanto a sua constituição estrutural. Se o indivíduo ideal pregado pelos iluministas não está podendo existir, dando espaço para outro tipo de organização psicológica, não será virando as costas a ela que se poderá transcendê-la.

A pesquisa quantitativa, portanto, pode ser usada criticamente e, nesse ponto, não é concorrente da qualitativa, assim como a pesquisa qualitativa também pode ser acrítica.

A investigação quantitativa pode captar o que o objeto está podendo ser, com os meios que falam a linguagem da coisificação, da tipificação, da padronização e da naturalização:

\footnotetext{
y agrupación generales."

3 "no todas las tipologías son sistemas tendientes a dividir el mundo en blanco y negro."
} 
“A reprodução social da vida, nas condições atuais, parece ser inteiramente impossível sem a transmissão, a entidades administrativas centrais, de informações exatas sobre as mais diversas e complexas relações sociais, que só podem ser obtidas mediante as técnicas da investigação social empírica.

Mas uma teoria da sociedade em que a transformação não seja apenas uma frase domingueira deve integrar a fatualidade, em toda a sua força de resistência, sob a pena de continuar sendo apenas um sonho impotente, cuja impotência só beneficia, uma vez mais, o poder do que está estabelecido." (Horkheimer e Adorno, 1973b, p.130).

Os métodos quantitativos, nos quais se inclui o teste psicológico, possuem duas faces: a de relações de produção e a de força produtiva. Nesse sentido, não apenas são gerados pelos aspectos progressivos e regressivos da razão, como também os corroboram e os produzem.

Sua importância na resistência à barbárie procede desde que a crítica vislumbre esse imbricamento, de modo que o teste psicológico deixe de ser visto apenas como "produtor" ou "vítima", seja de regressão, seja de desenvolvimento.

Se o pensamento basta-se com o que o dado é, temos de pensar o pensamento e não nos enganarmos com o método do qual ele lança mão. Vamos nos deter mais neste ponto.

O teste psicológico traz dados acerca da superfície social, seu aparecer. A obrigação do pensamento seria pensá-lo como uma etapa da investigação, tentando

\footnotetext{
“descobrir nos dados não apenas suas relações espácio-temporais abstratas, com as quais se possa então agarrá-las, mas ao contrário,
} 
pensá-las como a superfície, como aspectos mediatizados do conceito, que só se realizam no desdobramento de seu sentido social, histórico, humano." (Horkheimer e Adorno, 1991, p.39).

A intenção e prática de se fundar um modelo de psicologia próximo ao das ciências naturais e físicas teve um preço para o objeto da psicologia. Porém, este não se deve apenas ao igualamento do homem a seres inanimados ou irracionais, falseando o objeto, mas também ao fato de o método ter servido para o pensamento mergulhar o objeto psicológico na naturalização e na indiferenciação, sem delas sair. Por isso, pensar apenas o método não contempla a questão inteiramente.

Aludindo à relação entre testes de inteligência e a escola, Anastasi (1972) mostra em alguns momentos o desempenho na escola associado à inteligência. Essa ligação é perceptível pelas formas de validação de testes de inteligência que ela apresenta, para os quais se usam demonstrações do desempenho escolar do indivíduo. A escola é retratada como instituição neutra, na qual o bom ou mau desempenho deve-se apenas à capacidade intelectual.

Conforme questionou também Lawler (1981), não se aventa, contudo, que o formato e o conteúdo do teste, com papel, lápis, perguntas e respostas, assemelham-se às lições escolares. E que aquelas crianças que não tiveram acesso à escola ou que nela tiveram uma experiência negativa, já entram na testagem em desvantagem.

Anastasi (1972) indica essas diferenças, mas não as desenvolve: 
"A observação da atividade das crianças de classes sociais mais baixas durante os testes de rapidez leva-nos a pensar que muitas vezes essas crianças terminam rapidamente um teste, dando respostas mais ou menos ao acaso. Aparentemente, estão previamente convencidas de que não podem obter bom resultado no teste e que, terminando rapidamente, podem encurtar o período de mal-estar provocado pela prova." (Eells et al. ${ }^{4}$ apud Anastasi, 1972, p. 59).

Não obstante, se investigados os fatores dos fatos como sugere Marcuse (1967), a partir do que o método fornece sobre o objeto, sem se deixar petrificar por suas categorias lógicas, obtêm-se muitos dados.

Observe-se que, quando um teste se propõe a medir uma qualidade qualquer, ela é sempre a qualidade para alguma coisa, o que em si já mostra que o teste não é neutro.

Se o desempenho pode ser influenciado, se há reconhecimento de que, mudando a padronização ou a forma de organização dos itens, beneficiamos ou prejudicamos essas ou aquelas "categorias" de pessoas, mostra-se que o instrumento não é neutro, nem absoluto e nem seus resultados são "naturais". E, então, temos de reconhecer por quais categorias o pensamento está sendo guiado e qual a função delas na sociedade. Se o teste serve a uma racionalidade administrativa, que precisa separar os indivíduos em termos normativos e de ajustamento, insistimos que é essa necessidade que precisa ser pensada.

\footnotetext{
${ }^{4}$ Eells, K.; Davis, A.; Havighurst, R.J.; Herrick, V.E.; Tyler, R.W., Intelligence and cultural differences. Chicago, Chicago University Press, 1951.
} 
O problema não é investigar o fato, mas tratá-lo como imediato e bastar-se nele.

O comportamento, ou o que mais se investigue externamente, é uma parte do fenômeno investigado que está à mostra. O teste proporciona uma fotografia do real. Por exemplo, na normalização brasileira do Colúmbia, dadas as significativas diferenças entre os resultados das crianças provenientes de escolas privadas e escolas públicas, em favor das primeiras, Alves e Duarte (1993) acharam por bem criar duas subtabelas distintas para ambas as populações

O Colúmbia fotografou o real: o desempenho varia conforme a proveniência da escolaridade. Cabe ao sujeito do conhecimento pensar, primeiro, que esta fotografia não é ontológica, mas o que o indivíduo está podendo ser diante do teste, sob condições historicamente constituídas.

O teste deve ser um meio também de investigar o que o positivo traz de negação, ou seja, o que o sujeito não está podendo ser.

$\mathrm{Na}$ consideração do dado positivo, que é afirmativo, a lógica formal despreza o campo que está além da afirmação: “o julgamento afirmativo contém uma negação que desaparece na forma proposicional (S é p)." (Marcuse, 1967, p.133). Portanto, mesmo que seja uma técnica que se refira ao imediatamente dado, isso não necessariamente implica que ele fique solto, sem conceito, sem história e sem que a relação sujeito-objeto seja pensada de forma viva e presente. Até porque o que se manifesta empiricamente por meio do resultado do teste pode ser um epifenômeno (Horkheimer e Adorno, 1973a). 
Buscar a totalidade e apreendê-la, não levando em conta que o pensamento é produto da realidade e, que, por isso, esta busca tem limite no fato de que nenhuma relação sujeito-objeto é neutra e unilateral, abdica necessariamente de qualquer pretensão de verdade sobre o objeto.

Se, na produção e utilização dos instrumentos psicológicos de mensuração, cercando-se de procedimentos estatísticos, partir-se do imediatamente dado para apreendê-lo e voltar a ele sem conseguir transcendê-lo, cria-se uma alienação no imediatamente dado que apenas reafirma o existente. Um resultado rebaixado no teste termina por reiterar o que já se sabia: que, de fato, a criança testada, por exemplo, encaminhada pela escola por estar com problemas de aprendizagem, está deficiente quanto a certos conteúdos importantes para a adaptação social esperados para sua idade.

Se o teste está servindo a finalidades de dominação, temos de pensá-lo mediante as condições que possibilitaram que fosse criado.

O pensamento que identifica o universal em tudo e despreza o particular é mitológico. Não porque o universal não esteja sempre presente, mas porque o particular não pode ser desprezado. 0 contrário, no entanto, também é verdadeiro: não é possível pensar o particular sem o universal.

A partir do momento em que um teste psicológico se propõe realizar essa identificação de tudo com tudo, ele é falso se deixar de reconhecer o particular. Mas algumas críticas que às vezes se fazem a ele pecam por deixarem de reconhecer o universal, fixando o particular como única realidade. 
É mitológico também se fixa o factual como a única referência; se supõe que um objeto, cuja formatação foi feita de antemão, é o objeto em si mesmo e crê que o universal possa ser completamente contido num recorte particular que foi universalizado.

Tendo um forte aparato instrumental manipulador como premissa, a tecnologia atua também no controle e dominação sociais e, por isso, pode ser considerada como projeto político: “o a priori tecnológico é um a priori político." (Marcuse, 1967, p.150). O método apreende e categoriza a natureza conforme seus objetivos, e nesse sentido não é neutro. É como projeção que a ciência lida com a natureza:

“A ciência da natureza se desenvolve sob o a priori tecnológico que projeta a natureza como instrumento potencial, material de controle e organização. E a apreensão da natureza como instrumento (hipotético) precede o desenvolvimento de toda organização técnica particular." (p.150).

Nos procedimentos quantitativos, o estabelecimento de "denominadores comuns" torna-se necessário para o uso do resultado: não se pode elaborar um questionário que vai ser aplicado cada um de forma diferente, e querer computar todos os resultados como se tivessem sido aplicados uniformemente, ou mesmo estudar um número $\mathrm{N}$ de sujeitos, cada um segundo um aspecto diferente, e pretender depois quantificá-los.

Anastasi (1972) menciona a "necessidade de condições controladas." (p.28). Oliveira e Santiago (1987) asseveram que "a 
manutenção das condições padronizadas para a aplicação do teste é imprescindível, na medida em que reduz o número de variáveis que intervém na situação de testagem da inteligência." (p.71).

A uniformização das condições de aplicação, instruções, materiais, relacionamento com o sujeito etc. visa a redução da variância de erro, tornando os resultados do teste mais precisos (Anastasi, 1972). Por isso, é importante que as condições a que estava submetida a amostra-padrão sejam mantidas pelos aplicadores.

Entretanto, deve-se reconhecer que, em termos humanos, não se chegará a uma precisão de máquina e nem que o fenômeno conseguiu ser contido no pequeno universo controlado pelo cientista. A impossibilidade de replicação exata dos fenômenos é um fato. A estatística o sabe, prova disso é a noção de probabilidade. As curvas estatísticas são sempre probabilísticas, informando a tendência provável do evento, com uma margem de erro calculada; quanto menor o erro, maior a confiabilidade. Assim são as pesquisas de opinião, experimentos laboratoriais e testes psicológicos. A confiança na estatística é fundamentada e de modo algum uma atitude cega.

\section{2 - A objetividade do teste e a relação sujeito-objeto}

Uma parte do que foi abordado quando da exposição do qualitativo e do quantitativo faz sentido aqui. A relação sujeito-objeto 
tem inúmeras faces e uma delas é a caracterização qualitativa da subjetividade e quantitativa da objetividade, entendidas conforme o positivismo.

Quando o sujeito se volta para seu objeto como se ele existisse em si mesmo, recortado de quaisquer relações históricas e à parte de seu sentido no sujeito, como uma tentativa de salvação contra as figuras mitológicas que permanecem, é preciso avaliar que espécie de conhecimento se capta. A oposição sujeito-objeto tende a se dissolver pela operacionalização e matematização do método; o entrelaçamento das entidades subjetivas e objetivas vira um tabu e o homem não se mistura com a natureza para conhecê-la, o que inclui dizer sua própria natureza interna. O universo apreendido é o resultado das operações, como se fosse uma "substância objetiva lançada contra o sujeito." (Marcuse, 1967, p.146).

O teste psicológico, como recurso científico, poderia usar o afastamento como forma de se aproximar momentaneamente da realidade objetiva, mas isso não precisaria implicar a petrificação da relação sujeito-objeto. Na tensão sujeito-objeto abre-se um caminho para apontar a intencionalidade do método e é dela que surgem os subsídios para se pensar relações que o teste, simplesmente, como fotografia do imediatamente dado, não fornece.

Muitas vezes, crê-se que a questão da objetividade versus subjetividade resolver-se-ia a partir do momento em que, na hora da aplicação, o examinador passasse a incluir-se no momento da testagem, dinamizando a relação, aproximando-se de um modelo psicodinâmico de conduta: 
“... na realização de um teste de inteligência, o examinador deve considerar não somente as condições emocionais do examinando e as características da relação estabelecida entre ambos, mas também suas próprias manifestações subjetivas." (Oliveira e Santiago, 1987, p.71).

Contudo, a relação sujeito-objeto é mais do que a relação examinador-examinando. A relação examinador-examinando é pontual, singular e particular, circunscrevendo-se no "aqui e agora" das duas pessoas envolvidas. A relação sujeito-objeto é histórica; a relação examinador-examinando atualiza, no particular, esta historicidade. Não é apenas a subjetividade das pessoas versus a objetividade pretendida no instrumento de avaliação. Colocada dessa forma, a questão se falseia e aprofunda a cisão.

Além do mais, o entendimento da subjetividade e objetividade como instâncias que se opõem, as hipostasia e cinde, como se viu anteriormente.

Essa tentativa de dar mais movimento à hora da aplicação, por vezes utilizando-se de uma abordagem psicodinâmica, é importante e já seria, sem dúvida, uma tentativa de integração das partes dissociadas pelo método positivista de conhecimento. No entanto, a cisão já é parte integrante e constituinte do próprio teste e transcende a relação pessoal estabelecida no "aqui e agora" da aplicação. Questões como o controle da subjetividade como método de "eliminação" da emergência do particular, do desconhecido, para preservar o sujeito do horror mítico, por meio da naturalização do 
homem e da matematização do pensamento, por exemplo, ficariam de fora.

Não se pode romper com o teste e continuar utilizando-o sem conseqüências. O teste foi elaborado segundo os princípios que naturalizaram a ruptura entre sujeito e objeto. Se forem rompidos, tirarão seu sentido integral, como, por exemplo, da padronização estabelecida que, se não for observada, inviabiliza a aplicação das normas.

Quando se fala em sujeito, não se está se referindo a "boas" ou "más" intenções de quem aplica o teste. Se o teste já tem uma rede de significados construída a seu redor, como pensar que apenas a boa intenção ou consciência do profissional seja capaz de fazer com que a divulgação do resultado do teste ou o próprio momento da aplicação não reverta para o examinando a ele submetido como estigmatização e anulação? Ao teste são dadas funções, posto que não tem vida própria, que por sua vez não são cumpridas ao acaso. Antes mesmo de sua criação, muitas destas funções já estão dadas e determinaram o formato e objetivo do teste.

Além do mais, uma vez a testagem acontecendo, ela sai do controle do psicólogo aplicador - e de suas "intenções", sejam elas quais forem. Até na própria relação entre o profissional e seu cliente: como fazer para que o teste não anule o profissional ante o cliente e o cliente ante o profissional?...

A objetividade preconizada do teste, por sua vez, tem sua justiça. Mas, desde que a busca da verdade deixou de ser uma busca do "ser" para converter-se na busca de "fórmulas de administração" da 
realidade, a subjetividade pôde de fato ser descartada sem grandes impactos para os objetivos da investigação científica. A observação e mensuração do comportamento do objeto no imediatamente dado são passíveis de alcançar as pretensões científicas sem que para isso elas precisem de metafísica ou de indagações sobre o ser.

Tanto isso é verdade que a crítica à ciência é difícil de ser feita, pois muitas vezes soa como irracionalidade para os ouvintes, partidarismo, "esquerdismo" etc.

O esforço crítico parece ter uma chance se penetrar seu objeto e conseguir compreender o que nele permanece de verdade e de falsidade, sem negá-lo. É desta forma que se pode pensar que, apesar dos problemas do método científico, seus produtos não são mera ilusão de ótica. Se não se conhecem os fundamentos do teste, sua crítica corre o risco de não ter onde se embasar concretamente, podendo se perder.

Tirar do julgamento pessoal e idiossincrático do examinador o critério de escolha dos melhores é uma preocupação importante. Os testes em geral atendiam sobretudo no passado, à necessidade de classificação gerada em larga escala nas diversas instituições sociais, de forma econômica e "independente". No uso da estatística, na intenção da padronização e nos formalismos do método vemos explicitada essa preocupação.

Note-se que, quanto à independência do teste, poder-se-ia contra-argumentar o comprometimento ideológico das escalas de medida. Mas, de novo, corremos o risco de crer que exista neutralidade ou um lugar em que a intenção tenha sido suspensa 
sobremaneira, o que não é o caso. O teste, indubitavelmente, tira do viés do examinador a decisão digamos, imediata, sobre outrem, embora a intencionalidade não exista apartada do conhecimento científico.

Outro dado importante pertinente aos testes é a relação que estabelecem entre verdade e maioria. Sabe-se que o resultado de um indivíduo num teste provém de tabelas que são construídas a partir da testagem de uma amostra representativa da população de origem do testando. Desse modo, o desempenho da maioria é fundamental para balizar o resultado de um indivíduo num teste.

O teste mostra como o indivíduo está diante de uma determinada população e o resultado da amostra populacional é tomado como o parâmetro de comparação para aquilo que o teste visa medir. O resultado médio, ou seja, o valor médio do grupo, é a linha que vai demarcar a fronteira entre o adaptado e o desadaptado, o normal e o anormal, ou, traduzindo, o são e o doente, o certo e errado.

Nesse sentido, é interessante trazer um texto em que, ao tratar da opinião, Adorno (1969) mostra como a "verdade" está identificada com a "maioria", em nossos dias.

Uma certa opinião é, muitas vezes, tornada verdadeira apenas por ser a opinião que a maioria tem. A posição do indivíduo diante de seu grupo abona ou desabona sua opinião, comportamento ou desempenho. 
Adorno (1969), porém, questiona a soberania da maioria como portadora da verdade. A representatividade de uma idéia ou comportamento cumpre um papel como passaporte para seu estatuto de verdade. Implicitamente, há o pressuposto de que a maioria caminhe, estatisticamente, para a normalidade.

Existia, entretanto, uma razão para o teste buscar a maioria dos mais adaptados, que era a necessidade de diferenciá-la, o que não é inteiramente questionável e já foi discutido. Ainda que o teste se proponha diferenciar as qualidades que importam para a esfera produtiva e para a conservação do mundo tal como é, selecionando os indivíduos ajustados para a produção, essa utilidade carrega, inexoravelmente, a contradição interna da sociedade.

A psicometria trouxe uma resposta ao pensamento científico positivista, que é pragmático, preocupado com a eficiência e atém-se ao dado positivo, aplicando estes princípios aos fenômenos psicológicos. No âmbito das necessidades pragmáticas e administrativas, esta abordagem matemática é útil. A ciência não produziu só alienação. Tais métodos dão conta das necessidades práticas da vida da maneira como nenhuma especulação filosófica daria.

Por outro lado, se a sociedade necessita de conhecimento pragmático que facilite a administração, ela não necessita apenas disso. Embora o saber que não é pragmático seja impotente quanto à produção, nem por isso deixa de ser importante.

A seguir, conclui-se este trabalho. 


\section{6 \\ CONSIDERAÇÕES FINAIS}

O uso de testes não é descompromissado, como apontaram Lawler (1981) e Patto (1993), embora, diferentemente do que advogam esses autores, a neutralidade da ciência não esteja na filiação das idéias a uma classe social, mas ligada, primordialmente, à intenção da ciência de dominar a natureza pela manipulação.

Quando um teste é criado para medir um atributo humano, é sempre o atributo para alguma coisa, o que the põe uma franca delimitação.

A invisibilidade com que os limites do teste são tomados por muitos psicólogos não é apenas um problema de falha de formação em nível superior. Tampouco se insere num mecanismo ideológico clássico dentro 
da dialética de verdade e falsidade, e, portanto, de racionalidade e irracionalidade dos conteúdos do discurso ideológico, que tem por fim o mascaramento bem-sucedido da dominação de classe. A fetichização do teste, a absolutização do número, a transformação da medida do comportamento na medida de uma suposta essência imanente e a naturalização do homem relacionam-se ao enfraquecimento do pensamento e do subjugo deste à irracionalidade em nossos dias. Desse fato provêm os esforços desta dissertação em analisar o teste com vistas não apenas às relações externas com ele mantidas, mas às condições que possibilitaram sua criação e atual utilização. Torna-se importante examinar a adesão quase incondicional à técnica, em virtude da nova forma que a ideologia assume em nossos dias.

A perspectiva histórica adotada por Patto (1993) para compreender o fenômeno do fracasso escolar lançou luzes acerca do uso de testes nas escolas, no Brasil e em países capitalistas centrais. Nela, a autora propõese desvelar a ideologia que encobre o apelo à mensuração do indivíduo desajustado à escola (com baixo rendimento ou mau comportamento), na complementaridade criada entre pedagogia e psicologia.

Porém, a crítica ideológica não consegue ter o mesmo alcance que teria em outro momento histórico, pois os elementos racionais do discurso ideológico se desvaneceram, sobrando pouco com que ela possa desmontá-lo. Além disso, a crítica aos testes deve levar em conta também as mudanças ocorridas no papel dos testes, desde o momento de sua criação até os dias atuais. Para discriminar melhor todos esses 
elementos, é fundamental o conhecimento dos preceitos internos dessa técnica.

O foco no indivíduo surge num momento em que ele fica descoberto ante uma estrutura social cuja estabilidade e tradição foram rompidas com a mercantilização e posterior Revolução Industrial. Problemas, conflitos e questionamentos no âmbito do indivíduo têm espaço para aparecer. As ciências se especializam diante da demanda de entender, mesmo que de forma recortada, um mundo que começa a apresentar-se também recortado. Não apenas neste contexto surge a psicologia com diversas especializações, mas também a própria psicanálise.

Há uma tendência historicamente constituída de culpabilizar o indivíduo por seu desajuste social - desajuste que às vezes toma o nome de inaptidão, loucura ou deficiência, que é bem trabalhada em Patto (1993).

Entretanto, embora essas tendências históricas sejam acobertadas pela ideologia, elas são mais que isso. Apesar de a ciência psicométrica e de a psicologia diferencial terem sido, nos primórdios, ideologia, certamente não foram apenas isso. Elas ancoraram-se numa necessidade real da indústria moderna, que procurava meios eficientes de seleção e avaliação da mão-de-obra a ser empregada. Os testes surgiram num momento em que o mundo ocidental começava a se aparatar técnica e cientificamente; as produções científicas visavam "abastecer" esse mundo ainda rudimentar em termos de bem-estar material e selecionar os 
"melhores" e "mais aptos" era um imperativo nessas condições. Seu objetivo não era apenas o de fornecer uma resposta velada sobre os problemas estruturais que despontavam e ameaçavam a classe dominante e o status quo. Na escola, buscava-se diferenciar os indivíduos em prol de uma sociedade mais justa e para "bem" dos "melhores". Havia igualmente a necessidade de recrutamento de um largo contigente de soldados, pelos Estados Unidos, durante a Primeira Guerra Mundial.

Por outro lado, o uso de testes servindo a fins de justificação ideológica não pode ser negado, por exemplo, no momento em que a sociedade começou a se deparar com o fracasso escolar.

Como bem observou Marx (1975b), o desenvolvimento da indústria capitalista é contraditório e o maquinário apresenta em si essa contradição. A promoção do bem-estar humano e a possibilidade de alívio ante o trabalho árduo e o passo que a ciência representa no caminho da libertação diante da natureza não podem ser negados. Se hoje há o benefício das facilidades da informática, do controle de doenças que no passado dizimaram cidades inteiras, de remédios para aliviar a dor, de meios de transporte que aliviam animais e pessoas do encargo etc., eles são resultado do desenvolvimento da Revolução Industrial e do pensamento positivista, com todas as suas mazelas. Mediado pelo capital e acessível como mercadoria, produzido e disponível em larga escala aos homens por meio da coisificação de outros homens, ainda assim se consegue melhorar a vida com o conhecimento científico, embora essa mesma melhora seja também, inexoravelmente, barbárie. É a mutilação 
que a máquina executa no ato de alimentar (Horkheimer e Adorno, 1991).

Não se sabe como seria se tivesse sido diferente, ninguém pode dizer. Como seria nosso desenvolvimento científico se fosse conciliado com a natureza, se a ciência a visse verdadeiramente como um outro?

Atualmente, a expansão da esfera produtiva se dá de forma diferente, pelo incremento da tecnologia digital e computadorizada, pela globalização, pela velocidade da informação. $\mathrm{O}$ trabalho está desaparecendo. Não são mais necessárias tantas pessoas para construir o mundo, apenas o suficiente para manter o aparelho, que hoje adquiriu quase uma autonomia ante os homens - por mais sem sentido que isso pareça.

Desse modo, é legítimo apontar que as tarefas que muitos testes e psicólogos ainda se propõem, de continuarem reunindo esforços para selecionarem os mais "aptos" tornou-se anacrônica, denunciando assim seu caráter de pura ideologia, entendida conforme Horkheimer e Adorno (1978c).

O teste insere-se num certo entendimento de mundo e de homem, dando corpo a um grupo de idéias intricadas na educação e na psicologia. Ele interfere, auxilia este corpo e cria realidades, mas também vem ao encontro do desejo de objetivar estes ideários em ações e práticas clínicoeducacionais. Naturalização, "biologização" e "monadologismo" compõem esse corpus que se caracteriza pela cisão da dimensão cognitiva e 
emocional do processo sócio-histórico, o qual os instrumentos psicológicos de medida sintetizam.

Esse entrelaçamento de ideários e práticas deve ser pensado com vigor, para que novas práticas não substituam antigas, na esperança de romper ideários que permanecem vívidos.

Veja-se que, no caso das críticas à quantificação, parece-nos que a presença de testes projetivos, o aumento da ênfase em aspectos subjetivos do pesquisador e do sujeito, a menor ênfase na objetividade do processo e as análises qualitativas da psique humana encontradas na pesquisa bibliográfica realizada mostram que elas de alguma forma foram assimiladas. Isso evidencia que não se trataria, propriamente, de um diálogo de surdos entre os críticos da ciência e seus adeptos.

Entretanto, se não se pensar as condições que possibilitaram a expansão dos métodos quantitativos de mensuração das qualidades psíquicas do homem num primeiro momento, seus elementos regressivos básicos terminam sendo reproduzidos irrefletidamente. Propostas de trabalho qualitativo não são sinônimas de proximidade e respeito à particularidade, bem como a quantificação não representa apenas indiferenciação. Desta feita, faz sentido que, nos artigos pesquisados, algumas idéias de fundo continuem presentes e colaborando com a coisificação, como a naturalização e o fetichismo da técnica, apesar da mudança de enfoque observada. O mesmo vale para as propostas de avaliação sem testes e padronizações publicadas por Machado (1996) e Moysés e Collares (1997). 
Muitas vezes, atribui-se uma crítica ao teste que na verdade deveria recair sobre as relações coisificadas e fetichizadas que se tem com as técnicas, como se o instrumento inanimado adquirisse vida própria e qualidades a priori, independentes de si. Caso contrário, a extinção dos testes solucionaria os "males" por eles causados. Mas, sem a compreensão da coisificação do homem na sociedade, os testes seriam logo substituídos por outros processos igualmente criticáveis. Por exemplo, quando se parte para a utilização ou aceitação dos resultados de uma testagem sem que se tenha sequer conhecimento acerca do método empregado ou da população-alvo do teste, isso não é problema do teste. Se eles são usados para segregar e justificar a segregação, devemos pensar na segregação e não atribuir sua responsabilidade apenas à técnica usada para segregar.

É sabido que o teste só é válido se for aplicado à mesma população da qual se originou a amostra normativa. No Brasil, esse tópico é problemático. Uma série de testes utilizados não foram normalizados para o Brasil ou então contam com uma normalização antiga, prejudicando a confiabilidade do teste em ambos os casos.

É preciso discriminar, contudo, esse fenômeno do que preconiza a psicometria, sendo Anastasi (1972) veemente quanto à necessidade de normas adequadas ao se empregar um teste.

Esses equívocos encontram impulso para acontecer - mas não são gerados sozinhos - na compensação financeira e na praticidade do teste, junto ao fato de ser ele um instrumento científico e portanto, geralmente 
tomado como verdadeiro de antemão. Lembre-se também que a normalização implica um custo para a pesquisa, que geralmente não é baixo. Além disso, a má formação do psicólogo certamente colabora para o uso problemático dos testes em nosso meio.

Poupar dinheiro e trabalho não é, obviamente, "errado". É uma preocupação legítima, num mundo em que se depende dele para garantir a sobrevivência. Mas é preciso que o usuário de testes fique atento para que essa preocupação não acabe justificando sozinha 0 apelo ao instrumento, ofuscando possíveis equívocos em sua utilização. Fica a pergunta no ar: como pode um teste ser utilizado se está comprometido de antemão em um de seus aspectos fundantes, a normalização?

É necessário pensar amplamente a relação de poder e submissão que se mantém com essa classe de saber. Aceitar o resultado de um teste aplicado por outrem sem saber que teste foi utilizado ou aplicar um determinado teste sem conhecer sua história, a história de seus dados e sua conceitualização, por exemplo, passa a ser uma demonstração de fé no instrumento. Mas a fé pertence à religião...

A compreensão monadológica do homem é importante para a psicologia clínica, para a psicanálise e para a própria crítica ao status quo, por fornecer a elas o substrato necessário para que dêem as costas à sociedade e tratem do indivíduo a partir de categorias próprias. Porém, a separação indivíduo-sociedade não pode ser tomada como ontológica, cristalizando a dialética. Caso contrário, pode-se recair em noções particularistas nas quais as problemáticas individuais parecem imediatas e 
sem ligação com o todo ou, de outro lado, universalistas, nas quais o todo é tomado univocamente, negligenciando o fato de que a reprodução social também passa pelo particular. O resultado disso é verificável: esvaziamento da crítica social ante os problemas surgidos na escola e reprodução de práticas e discursos barbarizantes.

A dimensão emocional, com seus vínculos, identificações e objetos internos, assim como as transformações e características cognitivas do indivíduo, indubitavelmente, atravessa a aprendizagem e a vida escolar. Esta, todavia, deve ser tomada no âmbito de suas mediações com o todo, que são sociais, históricas, políticas, biológicas.

Uma das maiores contribuições de Adorno foi, segundo Habermas (1980), a concepção da sociedade como totalidade, a qual "não se constitui numa extensão lógica determinável mediante a agregação de seus componentes." (p.277) Em outras palavras, "o todo não é igual à soma de suas partes" (p.277), o que o retira da possibilidade de leitura da sociedade como um organismo no qual cada componente faz sua parte para a promoção do bem-estar do todo. Desse prisma, noções acerca do desenvolvimento do indivíduo em nosso mundo tais como harmonia, saúde e auto-regulação soam como ironia.

O homem se individua ao particularizar os universais culturais (Crochik, 1998b). Como discernir o que é inato, biológico ou natural em qualidades aferidas pelos testes como inteligência, maturidade mental, insegurança emocional? 
Conforme analisou Lawler (1981), a inteligência nos testes de Q.I. é operacionalmente tomada. Este não é um problema em si. Admitir que qualidades manifestam-se por meio do comportamento não é um postulado falso. A questão é o fato de os cientistas bastarem-se com a operacionalidade na pretensão de haverem abarcado o todo, dispensando o aprofundamento do conhecimento sobre o objeto.

Lawler (1981) denuncia o apriorismo dos testes. Como vimos, o apriorismo é estrutural no positivismo. Uma crítica aos testes não pode deixar de ser uma crítica à ciência positivista, que cindiu e hipostasiou sujeito e objeto e reduziu o pensamento ao pensamento matemático, bastando-se com definições operacionais.

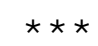

A crítica também não pode desconsiderar o teste no processo de trabalho: a rapidez e a eficiência que os testes buscam, imitando o ritmo maquinal, a tentativa de igualação do homem à máquina e seu imbricamento no aparato produtivo, sendo ao mesmo tempo produção e força produtiva.

O papel dos aplicadores chega a assemelhar-se ao de "auxiliares das máquinas" (Marx, 1975a, p.480) atribuído aos trabalhadores da indústria moderna. Sua função concentra-se basicamente em garantir à máquina, ou, no caso, ao teste, seu bom funcionamento. No uso capitalista da máquina - ou da técnica, num sentido mais amplo - a 
particularidade do trabalho e da qualificação do trabalhador dissolve-se, na medida em que o recurso tecnológico absorve a maior parte da função no processo. Este amplo lugar em que a técnica é colocada, deixando-a como um organismo quase autônomo, pode ser observado no espaço reservado ao aplicador dos testes psicológicos, que se defronta com um instrumento já pronto para o uso, sendo sua função padronizada de antemão.

À parte a exigência de qualificação profissional para manipular o teste $^{1}$, o instrumento em si não exige do aplicador muitos diferenciais, pois não apenas a função do aplicador é usualmente restrita, como é cercada de normas já contidas nos manuais dos próprios testes. Em muitos casos, um treinamento para aplicação talvez bastasse. O teste é um instrumento que visa de fato essa facilitação no emprego de mão-deobra que, contudo, não precisaria implicar reificação e fetichização.

O capital impulsiona e submete o processo de produção capitalista, ocorrendo o mesmo com o saber que incrementa a produção. A ciência entra no mercado com seus produtos, como o teste. Como mercadoria, visa lucro, e a forma capitalista de gerar lucro é aproveitar ao máximo o investimento feito no maquinário (no caso, o teste), produzindo maisvalia. Segundo Marx (1975a), a máquina na verdade aumenta o valor do

\footnotetext{
${ }^{1}$ Assim é que mesmo essa qualificação profissional requerida para manipular o teste pode não ser tanto uma necessidade do teste como uma norma social, mais vinculada ao discurso competente (Chauí, 1993), segundo o qual "não é qualquer um que pode dizer a qualquer outro qualquer coisa em qualquer lugar e em qualquer circunstância." (p.9). Ou, ainda, a demarcação de um território exclusivo de atuação profissional da classe psicológica.
} 
produto, mas, devido à produção em larga escala (em níveis a que nenhum trabalhador consegue chegar), este valor se dilui e tem por resultado o barateamento do custo. Desse modo, ela só é implantada onde seu investimento terá retorno e gerará lucro. Portanto, não apenas o lucro gerado não mais pertence aos produtores "diretos", como estes perdem o contato com outras partes do processo.

Se, como para Marcuse (1967), a ideologia está no próprio processo de produção, ao disponibilizar-se no mercado como mercadoria, o teste psicológico estaria vendendo não somente soluções para o que buscamos nele, mas também um certo estilo de atuação profissional e mesmo de vida, que passa a ser incorporado. Isso tudo numa cultura em que a mercadoria identifica o indivíduo e a racionalidade tecnológica aponta para o totalitarismo.

A psicometria, na seqüência do desenvolvimento científico, conseguiu sistematizar um método de aproximação unívoca a um objeto plurívoco.

Metodologicamente, as reduções são antes solução que problema. São facilitações de uma ciência que se aprimorou na identificação da eficiência com a verdade.

Os atributos medidos são, dado o objetivo do teste, aqueles que interessam à produção. Estes, mesmo que coadunados com a 
manutenção do status quo, não deixam de ser habilidades importantes e que estão sendo medidas.

Negar ao teste este movimento é negar a história e o próprio homem. O teste, como conhecimento humano acumulado, não pode ser descartado como se nada fosse. O que não significa que não se deva denunciar que a ciência colabore com a diferenciação do homem para a produção e não como indivíduo.

Diante de pluralidades e movimentos desconhecidos do homem, as ciências positivistas são alternativas que dão guarida contra o horror mítico. Mas, se pensamos nas alternativas e não pensamos no horror, as alternativas são substituídas por outras que continuarão servindo de capa contra o horror.

A indiferenciação que a matemática na psicologia impõe a seu objeto corresponde a uma indiferenciação do homem na vida social como um todo. Se hoje a vida social imita a alienação e repetição da natureza, esta é já uma questão social e não natural. Pensá-la como um dado ontológico é fruto da reificação em que se está submerso: já é fenômeno social.

Todo e qualquer tipo de técnica pode e deve ser utilizada para aliviar o homem do trabalho alienado, mas, tal como está atualmente, ela está contribuindo para inseri-lo de novo na alienação.

O teste deve ser colocado em seu devido lugar, como instrumento e não como o sujeito da relação. Ao emular a máquina que ele mesmo criou, deixando que uma suposta racionalidade imanente das coisas seja 
o sujeito do conhecimento, o homem se coisifica. O instrumento não precisa assumir o lugar do próprio pensamento, do pensar o objeto, servindo à dominação a qualquer preço, que depois termina se voltando contra o homem.

O teste psicológico, como técnica, não precisa, necessariamente, vincular-se a uma "consciência tecnocrática." (Crochik, 1990, p.119). A técnica, "que não visa conceitos e imagens, nem o prazer do discernimento, mas o método, a utilização do trabalho de outros, o capital" (Horkheimer e Adorno, 1991, p.20), não deve ser simplesmente eliminada mas re-significada (Crochik, 1990).

Um dos produtos da consciência tecnocrática é a crença generalizada na incompetência dos sujeitos para enfrentar questões referentes à subjetividade sem ajuda técnica - campo no qual os testes psicológicos atuam diretamente -, pois ela é

“produzida, de um lado, pela esfera pública, com o trabalho fragmentado nas diversas especialidades e nas montagens em série, diluídas na administração científica e burocrática e, por outro, pela esfera privada (que está invadida pela pública), fragmentando-se na recorrência a diversos especialistas que a pautam pela normalidade científica, assim como nos diversos modelos ofertados pelos pais, professores, meios de comunicação de massa (...) volta-se para o imediato, pois identifica a prática possível com a prática atual submetida à técnica." (p.119). 
A superação da consciência tecnocrática deve visar sua inclusão em outra totalidade, que não apenas a tecnológica. Trata-se de negar a técnica tal como está, estudando "a possibilidade dela vir a ser incorporada em uma consciência não tecnocrática vinculada à noção de totalidade histórica." (Crochik, 1990).

O uso dos testes poderia se dar para "fotografar" a posição de determinado indivíduo diante de determinados conteúdos, noções, atitudes, visão de mundo que o teste em questão estaria comungando.

São questões vitais e ao mesmo tempo difíceis para uma proposta baseada na referência ao dado imediato, pois, "na redução do pensamento a uma aparelhagem matemática, está implícita a ratificação do mundo como sua própria medida." (Horkheimer e Adorno, 1991, p.38). A subsunção do pensamento ao factual e sua tomada como a instância objetiva e "correta" da realidade criaram tal imanência que viraram um fato natural. Como a matemática é tida como a única com poder de penetrar a realidade sem deturpá-la com "subjetividades", o método virou o sujeito do conhecimento. O sujeito renuncia ao envolvimento com o objeto como forma de conhecer, colocando o método em seu lugar e reduzindo-se a mero "título que dá o direito a protocolar e sistematizar." (Horkheimer e Adorno, 1991, p.38).

A ciência promoveu e projetou a dominação e a possibilidade de emancipação do homem, que se mostram no aparato produtivo tecnológico, quando se une a ordem racional com a social. A verdadeira subversão estaria na trilha de uma nova noção de racionalidade que fosse 
capaz de ser negativa e histórica e, assim, transcender o universo social estabelecido, superando sua forma atual.

O esclarecimento deve refletir sobre seus próprios elementos regressivos para não ser por ele vitimizado e perder sua relação com a verdade, mas "só o pensamento que se faz violência a si mesmo é suficientemente duro para destruir os mitos." (Horkheimer e Adorno, 1991, p.20). 


\section{REFERÊNCIAS \\ BIBLIOGRÁFICAS}

ADORNO, Theodor W. Intervenciones. Caracas, Monte Avila Ed., 1969.

ADORNO, Theodor W. Tipos y síndromes. In: ADORNO, Theodor W.; FRENKEL-BRUNSWIK, Else; LEVINSON, Daniel.; SANFORD, Nevitt R. e col. La personalidad autoritaritaria. Buenos Aires, Proyección, 1965.

ADORNO, Theodor W.; HORKHEIMER, Max. Dialética do esclarecimento. Rio de Janeiro, Jorge Zahar, 1991.

- Preconceito. In:

Temas básicos da sociologia. ADORNO, Theodor W. e HORKHEIMER, Max, orgs., São Paulo, Cultrix/Edusp, 1973a.

investigação social empírica. In: Temas básicos da sociologia. ADORNO, Theodor W. e HORKHEIMER, Max, orgs., São Paulo, Cultrix/Edusp, 1973b. 
Ideologia. In:

Temas básicos da sociologia. ADORNO, Theodor W. e HORKHEIMER, Max, orgs., São Paulo, Cultrix/Edusp, 1973c.

ALMEIDA, Leandro S. O psicólogo educacional em Portugal: caracterização de tarefas, dificuldades e perspectivas futuras. Arquivos Brasileiros de Psicologia. Rio de Janeiro, v.41, n.2, p.106-20, 1989.

AMIRALIAN, Maria Lúcia. O diagnóstico da deficiência mental. Boletim de Psicologia. São Paulo, n.102, p.35-44, 1995.

ANASTASI, Anne. Psicologia diferencial. São Paulo, E.P.U., 1974.

. Testes psicológicos. São Paulo, Herder/Edusp,

1972.

ANCONA-LOPEZ, Marília. O uso dos testes de inteligência. In: Avaliação da inteligência. ANCONA-LOPEZ, Marília, org., São Paulo, 1987.

BIZZO, Nelio. Eugenia: Quando a biologia faz falta ao cidadão. Cadernos de Pesquisa. São Paulo, n.92, p.38-52, 1995.

BORGES, Luiza A.C.; LOUREIRO, Sonia R. O desenho da família como instrumento de avaliação clínica de um grupo de crianças 
encaminhadas para atendimento psicopedagógico. Arquivos Brasileiros de Psicologia. Rio de Janeiro, v.42, n.2, p.106-14, 1990.

BUSSAB, Wilson O.; MORETTIN, P.A. Estatística básica. São Paulo, Atual, 1994.

BZUNECK, José A. Crenças de auto-eficácia de professoras do primeiro grau e sua relação com outras variáveis de predição e de contexto. Arquivos Brasileiros de Psicologia. Rio de Janeiro, v.48, n.4, p.5790, 1996.

CAPOVILLA, Fernando C.; MACEDO, Elizeu C.; CAPOVILLA, Alessandra S.; THIERS, Valéria O.; DUDUCHI, Marcelo. Versões computadorizadas de testes psicométricos tradicionais: estendendo as fronteiras da psicometria para abarcar populações especiais. Boletim de Psicologia. São Paulo, v.46, p.1-19, 1997.

CARELLII, Antonio. O caráter urbano da habilidade mental. Boletim de Psicologia. São Paulo, n.100/101, p.15-9, 1994.

CARNEIRO, Eliane G.; FERREIRA, Izabel da C. - O teste INV de Pierre Weil e as provas operatórias de Piaget: um estudo correlacional. Arquivos Brasileiros de Psicologia. Rio de Janeiro, v.48, n.1, p.5581, 1996. 
CARONE, Iray. Teoria Crítica e psicologia social: o impacto do Instituto de Pesquisa Social na investigação psicossocial In: Psicologia e política. AZEVEDO, Maria Amélia e MENIN, Maria Suzana, orgs., São Paulo, Cortez/FAPESP, 1995.

CHAUÍ, Marilena de Souza. Cultura e democracia. São Paulo, Cortez, 6.ed, 1993.

COLLARES, Cecília A.L.; MOYSÉS, Maria A. Educação, saúde e formação da cidadania na escola. Educação e Sociedade. São Paulo, n.32, p.73-87, 1989.

CORRÊA, Jane; MOURA, Maria Lucia de. Uso de "provas piagetianas" como instrumento diagnóstico: questionando uma prática consensual. Cadernos de Pesquisa. São Paulo, n.79, p.26-30, 1991.

CROCHIK, José Leon. A (im)possibilidade da psicologia política In: Psicologia e política. AZEVEDO, Maria Amélia e MENIN, Maria Suzana, orgs., São Paulo, Cortez/FAPESP, 1995.

O "ajustamento" do pensamento em uma sociedade de alto desenvolvimento tecnológico: o computador no ensino. São Paulo, Tese (Doutorado), Universidade de São Paulo, 1990. 
consciência. São Paulo, Casa do Psicólogo, 1998a.

. Os desafios atuais do estudo da subjetividade

na psicologia. Psicologia USP. São Paulo, v.9, n.2, p.69-85, 1998b.

CUNHA, Jurema A.; FREITAS, Neli K.; RAYMUNDO, Maria da G.

Psicodiagnóstico-R. Porto Alegre, Artes Médicas, 4. ed., 1993.

DUARTE, Walquiria F. A percepção dos colegas através do desenho cinético da escola (KSD) em crianças paulistanas de $1^{a}$ a $4^{a}$ série. Boletim de Psicologia. São Paulo, v.XLV, n.103, p.7-16, 1995.

. O desenho cinético da escola (KSD): análise dos tamanhos e das distâncias entre os personagens desenhados. Boletim de Psicologia. São Paulo, v.XLVIII, n.108, p.13-25, 1997.

FRANCO, Maria L.P. Pressupostos epistemológicos da avaliação educacional. Cadernos de Pesquisa. São Paulo, n.74, p.63-7, 1990.

FONSECA, Vitor da; SANTOS, Francisco; CRUZ, Vitor. Avaliação dos efeitos do programa de enriquecimento cognitivo (PEI) em jovens pescadores integrados num processo de formação em alternância. Arquivos Brasileiros de Psicologia. Rio de Janeiro, v.46, n.1/2, p.48-62, 1994. 
FREITAG, Bárbara. Escola, estado e sociedade. São Paulo, Moraes, 4. ed., 1986.

GALDO, Neyde J.I. Avaliação precoce: diagnóstico prescritivo. Arquivos Brasileiros de Psicologia. Rio de Janeiro, v.41, n.4, p.7187, 1989.

GOLFETO, José H.; LOUREIRO, Sonia R. Avaliação multidisciplinar das características comportamentais e das condições de saúde de um grupo de crianças de um parque infantil de Ribeirão Preto. Arquivos Brasileiros de Psicologia. Rio de Janeiro, v.41, n.1, p.99-109, 1989.

GRAMINHA, Sônia S. Problemas emocionais/comportamentais e nível de escolaridade da criança. Arquivos Brasileiros de Psicologia. Rio de Janeiro, v.48, n.3, p.16-29, 1996.

GRASSANO, Elsa N. El valor operativo y functional del diagnostico en la clinica. Boletim de Psicologia. Il Encontro de Técnicas de Exame Psicológico: Ensino, Pesquisa e Aplicações. São Paulo, v.XLVII, n.107, p.39-45, 1997.

GUZZO, Raquel L. O psicodiagnóstico e a psicopedagogia. Boletim de Psicologia. II Encontro de Técnicas de Exame Psicológico: Ensino, Pesquisa e Aplicações. São Paulo, v.XLVII, n.107, p. 25-26, 1997. 
HABERMAS, Jürgen. Teoria analítica da ciência dialética. In: Textos escolhidos, col. Os pensadores. São Paulo, Abril Cultural, 1980.

JACQUEMIN, Andre. As técnicas de exame psicológico como instrumento de pesquisa e objeto de pesquisa. Boletim de Psicologia. II Encontro de Técnicas de Exame Psicológico: Ensino, Pesquisa e Aplicações. São Paulo, v.XLVII, n.107, p.57-68, 1997

LALANDE, Andre. Vocabulário técnico e crítico da filosofia. São Paulo, Martins Fontes, 1996.

LARRABURE, Sílvia Ancona-Lopez. Os testes de inteligência. In: Avaliação da inteligência. ANCONA-LOPEZ, Marília, org., São Paulo, 1987.

LAWLER, James M. Inteligência, hereditariedade e racismo. Lisboa, Editorial Caminho, 1981.

LOUREIRO, Sonia R.; MARTURANO, Edna M.; LINHARES, Maria B.; MACHADO, Vera L.; SILVA, Rosângela A. da. Crianças com queixa de dificuldade escolar: avaliação psicológica através de técnica gráfica. Arquivos Brasileiros de Psicologia. Rio de Janeiro, v.43, n.3/4, p. 161-82, 1994. 
MACHADO, Adriana Marcondes. Crianças de classe especial - efeitos do encontro da saúde com a educação. São Paulo, Casa do Psicólogo, 1994.

\section{Reinventando a avaliação}

psicológica. São Paulo, Tese (Doutorado), Universidade de São Paulo, 1996.

MACHADO, Vera L.; MARTURANO, Edna M.; LOUREIRO, Sonia R.; LINHARES, Maria B.; BESSA, Léa C. Crianças com dificuldades na aprendizagem escolar: características de comportamento conforme avaliação de pais e professores. Arquivos Brasileiros de Psicologia. Rio de Janeiro, v.46, n.3/4, p.119-38, 1994.

MARCONI, Alice I.; GRAMINHA, Sônia S. Relatório de avaliação psicológica da clientela de classe especial para deficiente mental. Arquivos Brasileiros de Psicologia. Rio de Janeiro, v.44, n.3/4, p.140-155, 1992.

MARCUSE, Herbert. I deologia da sociedade industrial. Rio de Janeiro, Zahar, 1967.

Razão e revolução. Rio de Janeiro, Paz e Terra,

4. ed., 1988. 
MARX, Karl. A maquinaria e a indústria moderna. In: O capital. Livro 1, 1. Rio de Janeiro, Civilização Brasileira, 1975a. . O fetichismo na mercadoria: seu segredo. In: O capital. Livro 1, 1. Rio de Janeiro, Civilização Brasileira, 1975b.

MELLO, Magaly G. Estudo comparativo da escala verbal do WISC adaptada por Paine e Lemgruber com a escala traduzida por Poppovic. São Paulo, Dissertação (Mestrado), Universidade de São Paulo, 1998.

MERANI, Alberto L. Psicologia e alienação. Rio de Janeiro, Paz e Terra, 1977.

MIRANDA, Marília G. de. Trabalho, educação e construtivismo: a redefinição da inteligência em tempos de mudanças tecnológicas. Educação e Sociedade. São Paulo, n.51, p.324-37, 1995.

MOYSÉS, Maria A.A.; COLLARES, Cecília, A.L. Inteligência abstraída, crianças silenciadas: as avaliações de inteligência. Psicologia USP. Psicologia e Razão Instrumental, v.8, n.1, p.63-89, 1997.

MUELLER, F.-L. História da psicologia, da antigüidade aos dias de hoje. São Paulo, Cia. Editora Nacional, 1978. 
MÜNSTENBERG, Hugo (1913). Psychology and industrial efficiency. New York, Arno Press, 1973.

OLIVEIRA, Lina G. M.; SANTIAGO, Mary D. E. A influência da relação bipessoal na utilização dos testes de inteligência. In: Avaliação da inteligência. ANCONA-LOPEZ, Marília, org., São Paulo, 1987.

OLIVEIRA, Vera de B. O psicodiagnóstico e a psicopedagogia. Boletim de Psicologia. II Encontro de Técnicas de Exame Psicológico: Ensino, Pesquisa e Aplicações. São Paulo, v.XLVII, n.107, p.35-38,1997.

PATTO, Maria Helena S. A produção do fracasso escolar. São Paulo, T.A. Queiroz, 1993.

ROMANELLI, Otaíza de O. História da educação no Brasil. Petrópolis, Vozes, 22.ed., 1999.

RUBIANO, Márcia R. Avaliação do desenvolvimento infantil em creche. Arquivos Brasileiros de Psicologia. Rio de Janeiro, v.44, n.1/2, p.42-52, 1992.

SANTOS, Manoel A. dos. Caracterização da clientela de uma clínica psicológica da prefeitura de São Paulo. Arquivos Brasileiros de Psicologia. Rio de Janeiro, v.42, n.2, p.79-94, 1990. 
SILVA, Franklin Leopoldo e. Conhecimento e razão instrumental. Psicologia USP. Psicologia e Razão Instrumental, v.8, n.1, P.11-31, 1997.

SPEARMAN, Charles. Las habilidades del hombre - su naturaleza y medición. Buenos Aires, Paidos, 1955.

TERMAN, Louis M.; MERRILL, Maud A. Medida de la inteligencia. Madrid, Espasa-Calpe, 1966.

THORNDIKE, Robert L. e HAGEN, Elizabeth. Measurement and evaluation in psychology and education. S.I., John Wiley \& Sons, 1969.

VISCA, Jorge P. L. Las variables cognitivo-afetivo-sociales del aprendizage. Boletim de Psicologia. II Encontro de Técnicas de Exame Psicológico: Ensino, Pesquisa e Aplicações. São Paulo, v.XLVII, n.107, p.27-33, 1997.

VYGOTSKY, Lev Semenovitch. A formação social da mente. São Paulo, Martins Fontes, 1991. 